UNIVERSIDADE DE SÃO PAULO

FACULDADE DE EDUCAÇÃO

EDUARDO PEREIRA BATISTA

Entre a fragilidade da educação e a potência da escola:

Ensaios sobre a constituição de um alguém 


\title{
Entre a fragilidade da educação e a potência da escola: Ensaios sobre a constituição de um alguém
}

\author{
Versão Corrigida
}

Tese apresentada à Faculdade de Educação da Universidade de São Paulo para obtenção de título de doutor em Educação.

Área de concentração: Cultura, Filosofia e História da Educação

Orientador: Prof. Dr. José Sérgio Fonseca de Carvalho 
BATISTA, E. P. A fragilidade da educação e a potência da escola: ensaios sobre a constituição de um alguém. 2021. Tese (Doutorado em Educação) - Faculdade de Educação, Universidade de São Paulo, São Paulo, 2021.

Aprovado em:

\section{Banca examinadora}

$\operatorname{Prof}(\mathrm{a}) . \operatorname{Dr}(\mathrm{a})$. Instituição:

Julgamento: Assinatura:

$\operatorname{Prof}(\mathrm{a}) . \operatorname{Dr}(\mathrm{a})$ Instituição:

Julgamento: Assinatura

Prof(a). Dr(a). Instituição:

Julgamento: Assinatura:

Prof(a). Dr(a). Instituição:

Julgamento: Assinatura:

Prof(a). Dr(a). Instituição:

Julgamento: Assinatura: 
Autorizo a reprodução e divulgação total ou parcial deste trabalho, por qualquer meio convencional ou eletrônico, para fins de estudo e pesquisa, desde que citada a fonte.

Catalogação da Publicação

Ficha elaborada pelo Sistema de Geração Automática a partir de dados fornecidos pelo(a) autor(a) Bibliotecária da FE/USP: Nicolly Soares Leite - CRB-8/8204

Batista, Eduardo Pereira

Entre a fragilidade da educação e a potência da escola - ensaios sobre a constituição de um alguém / Eduardo Pereira Batista; orientador José Sergio Fonseca de Carvalho. -- São Paulo, 2021. $126 \mathrm{p}$.

Dissertação (Mestrado - Programa de Pós-Graduação Cultura, Filosofia e História da Educação) -Faculdade de Educação, Universidade de São Paulo, 2021 .

1. Educação. 2. Ética. 3. Escola. 4. Mundo Comum. I. Fonseca de Carvalho, José Sergio, orient. II. Título. 
Para Rodrigo e Gustavo, com quem a cada dia reinvento meu devir-pai. 


\section{AGRADECIMENTOS}

A escrita dessa tese exigiu de mim um longo período de isolamento - bem maior que o período de isolamento social exigido até agora pela pandemia -, no qual, a sós comigo mesmo, pude estar na companhia de homens e mulheres ilustres que deixaram suas obras muito antes ou logo após minha chegada no mundo; pude me tornar contemporâneo desses autores na exata medida do alcance de minha compreensão. Ao fim desse longo período, minha esperança é a de que novos começos venham a eclodir dessa obra, que não teria sido escrita do mesmo modo não fosse o entrelaçar de minha biografia com outras estórias de vida. Agradecer aqui significa revelar essa teia de relações na qual, durante esse período, minha estória de vida esteve entrelaçada.

Agradeço imensamente à minha família, especialmente aos meus pais, Aparecida Pereira e José Batista, que, embora nunca tenham ingressado como alunos em uma universidade, sempre me apoiaram incondicionalmente em minha trajetória acadêmica.

Aos meus filhos, Rodrigo e Gustavo, que, em alguns dos momentos mais difíceis desse processo, carinhosamente me acolheram com pequenos gestos e carinhosas palavras.

Ao meu orientador, prof. José Sérgio Fonseca de Carvalho, que se tornou para mim um exemplo de quem, por seu rigor e generosidade intelectuais, sabe como cuidar das obras do passado e compartilhar o mundo que possuímos em comum.

Ao prof. Rodrigo Alves Neto e à profa. Crislei Custódio, cujas arguições na banca de qualificação foram decisivas para redefinir o ponto de partida dessa obra e abrir um novo caminho para o pensamento.

Aos membros do Grupo de Estudos sobre Educação e Pensamento Contemporâneo (GEEPC-USP), André Toledo, Anita Soares, Any Lamas, Deni Fazio, Jonas Waks, Jana Klinko, Taís Araújo, Thiago Leite, Thiago Marquetti, Thiago Moreira e Sandra Leite que me acolheram desde o início e, como leitores, ajudaram-me a pensar mais devagar e a resolver os problemas do texto. Em especial a Carol Fanizzi e Mari Evangelista com quem tive a alegria de compartilhar um pouco das vicissitudes da vida.

Aos amigos do Fórum Paulista de Educação Infantil (FPEI), em especial a Fernanda Souza, Mairise Souza, Peterson Rigato e Renata Dias; e aos do Coletivo de Professores de Vinhedo, especialmente Potiguara Lima, Simone Lima, Vinicius Dias e Virginia Baldin, com os quais tenho tido a honra de produzir cenas de dissenso e agir em concerto. 
Aos membros do Núcleo de Estudo de Filosofia e Religião (NEFIR-Soka Gakkai), especialmente a Wilson da Silva, por criar as condições de possibilidade para um diálogo fecundo entre o pensamento filosófico e o budismo de Nichiren Daishonin; e também a Júlio César, Jony e Cláudio por fazerem ressoar o sutra da Flor de Lótus pelo interior paulista.

Às amigas e aos amigos do Vilarejo do Bosque, pela coragem de empreender algo novo no mundo e por me acolherem nesse projeto lindo que me propicia inventar outra forma de vida.

E àquelas pessoas com quem tive o prazer e a honra de compartilhar as encruzilhadas do pensamento, as dificuldades da escrita e as alegrias, entremeadas pelas tristezas, da vida: Ana Lúcia Goulart (que, mesmo vivendo longe, está sempre por perto), Elaine Martins (que sabe como transformar as paixões da alma), Fabi Canavieira (cuja amizade me faz perder a noção do tempo), Mari Pedrassa (com quem pude aprender um pouco mais sobre mim mesmo), Caio Antunes (com quem caminho junto desde os primeiros passos acadêmicos), Marcelo Vieira (que semeia sonhos pelo mundo e age, incansavelmente, para realizá-los) e Rineu Quinalia (que inventa mundos possíveis e me provoca também a inventá-los). 
Educação é o ponto no qual decidimos se amamos o mundo o bastante para assumirmos a responsabilidade por ele e, com tal gesto, salvá-lo da ruína que seria inevitável não fosse a renovação e a vinda dos novos e dos jovens. E educação é, também, onde decidimos se amamos nossas crianças o bastante para não expulsá-las de nosso mundo e abandoná-las a seus próprios recursos, e tampouco arrancar de suas mãos a chance de empreender algo novo, algo imprevisto por nós, mas preparalas previamente para a tarefa de renovar um mundo comum.

Hannah Arendt. A crise na educação

O termo 'mundo' tem, pois, o significado que todos entendemos ao dizermos de um recém nascido que veio ao mundo. Para mim, o mundo é o conjunto das referências desvendadas por todo tipo de texto, descritivo ou poético que li, compreendi e amei.

Paul Ricoeur, A teoria da interpretação 
BATISTA, Eduardo Pereira. Entre a fragilidade da educação e a potência da escola: ensaios sobre a constituição de um alguém. 2021. No. de folhas. Tese (Doutorado) - Faculdade de Educação, Universidade de São Paulo, 2021.

Entre a fragilidade da educação e a potência da escola: ensaios sobre a constituição de um alguém

A partir da análise arendtiana da condição humana, pode-se afirmar que toda educação digna desse nome jamais se limita à mera aquisição de conhecimentos ou ao simples desenvolvimento de competências e habilidades. À luz de Hannah Arendt e Paul Ricoeur, buscamos iluminar o aspecto ético da educação e pensar essa atividade como um modo de relação com as obras e os monumentos do passado; um modo de relação que sabe como cuidar das coisas que possuímos em comum e julgamos dignas de permanecer no mundo. Nessa relação que o sujeito da educação estabelece consigo mesmo diante das obras e dos monumentos do passado é que um ser humano novo e em processo de vir a ser se constitui como um alguém. Buscamos ainda pensar sob quais condições a escola pode se tornar um lugar adequado para que um mundo de coisas interposto entre nós possa ser visto e lembrado pelas novas gerações, cuja tarefa é renovar nosso mundo comum.

Palavras-chave: Educação. Escola. Ética. Mundo Comum. 
BATISTA, Eduardo Pereira. Between fragility of education and potency of school: essays on constitution of someone.

Between fragility of education and potency of school: essays on constitution of someone

Based on arendtian analysis of the human condition, it might be assert that all education worthy of the name never bounds to mere knowledge aquisition or simple development of skills and competencies. In the light of Hannah Arendt and Paul Ricoeur, we seek to enlighten the ethical aspect of education and to think such activity as a mode of relationship with works and monuments from the past; a very suited mode whose know how to handle all that we have in common and we judge worthy of remaing in the world. By this relationship that a new human being and in process of becoming stablished with himself in face of works and monuments from the past, the subject of education constitutes as someone. Also we search to think under with conditions school can become a suitable place for the worldly things interposed between us may be seen and remembered for new generations, whose task is to renew a common world.

Keywords: Education. School. Ethics. Common world. 


\section{SUMÁRIO}

1 INTRODUÇÃ

2 UMA ANTROPOLOGIA FILOSÓFICA PARA A EDUCAÇÃO..................... 15

2.1 A interpretação de Paul Ricoeur ........................................................................ 16

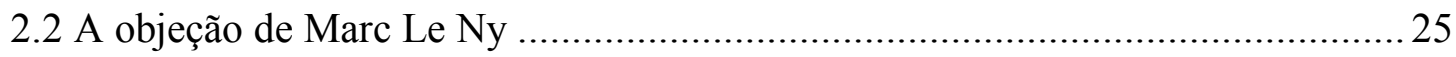

2.3 A atividade da educação e condição temporal de seres mortais ........................... 35

\section{A FRAGILIDADE DA EDUCAÇÃO NA CONSTITUIÇÃO DE UM}

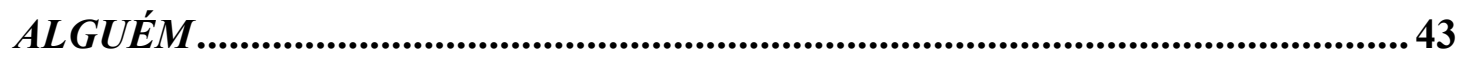

3.1 A desproporção íntima de seres temporais que pensam o que está fora do tem.... 46

3.2 A atividade da educação entre o trabalho, a obra e a ação .................................. 58

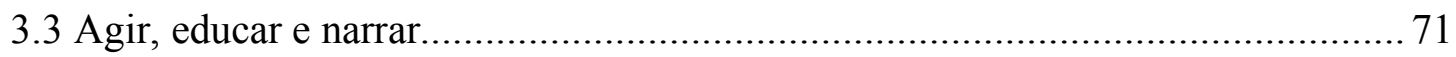

4 A INVENÇÃO DA SKHOLE : A ORIGEM E A POTÊNCIA DA ESCOLA ...... 78

$4.1 \mathrm{O}$ fio rompido da tradição e a ameaça do esquecimento .................................... 81

4.2 Interpretar-se diante dos fragmentos do passado ............................................ 92

4.3 A invenção da skhole e a potência da escola ................................................... 98

4.4 De como é possível pôr em ato a potência da escola ........................................107

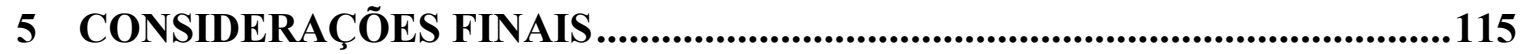

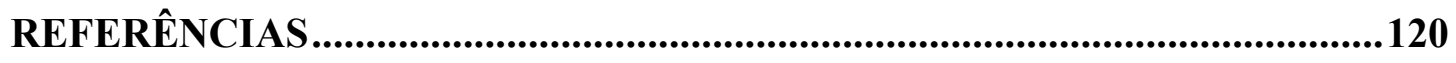




\section{INTRODUÇÃO}

\begin{abstract}
Basicamente estamos sempre educando para um mundo que está ou está se tornando fora do eixo (that is or is becoming out of joint), pois essa é a situação humana básica, na qual o mundo é criado por mãos mortais para servir de lar aos mortais por um tempo limitado. Porque o mundo é feito por mortais, ele se desgasta; e porque seus habitantes continuamente mudam, ele corre o risco de se tornar tão mortal como eles. A fim de preservar o mundo contra a mortalidade de seus criadores e habitantes, ele deve ser constantemente posto em ordem de modo novo (set right anew). O problema é simplesmente educar de tal maneira que um pôr-em-ordem (setting-right) continue sendo efetivamente possível, mesmo que isso, é claro, nunca possa ser assegurado.
\end{abstract}

Hannah Arendt, A crise na educação

As palavras de Hamlet, escreve Arendt no ensaio A crise na educação, são mais ou menos verdadeiras para cada nova geração, ainda que sua validade talvez tenha se tornado, desde o início do século XX, cada vez mais persuasiva. Na peça de Shakespeare, após ver e ouvir o espectro de seu pai que clama por vingança, Hamlet diz tais palavras que são citadas diretamente por Arendt: "The time is out of joint. O cursed spite that ever I was born to set right" (O tempo está fora do eixo. Oh! Fado odioso ter justo eu nascido para pô-lo em ordem). Essas palavras são mais ou menos verdadeiras para os recém chegados em um mundo que, em nosso caso, já está ou desde muito esteve fora do eixo. Ao contrário da vingança, para que efetivamente seja possível pô-lo em ordem de modo novo, é preciso romper o círculo vicioso do ódio e da violência. Ainda que seja preciso urgentemente lutar contra as diversas formas de dominação e violência que, nos dias de hoje, parecem ter sido disseminadas em escala planetária pela ideologia da guerra e da destruição, pensar a educação como um instrumento para o que quer que seja - implica destituir essa atividade de sua dignidade. Ainda que seja premente nossa tarefa de pôr em ordem um mundo que já está fora do eixo, pensar a educação a partir das categorias de meios e fins implica privar essa atividade de seu significado.

Tentaremos aqui restituir a dignidade e iluminar o significado da atividade da educação. Nesse sentido, o problema da educação poderia ser colocado nos seguintes termos: como é possível pensar a educação em um mundo que está fora do eixo, de modo que um pôr-emordem continue sendo efetivamente possível, isto é, que a oportunidade face ao novo não seja arrancada das mãos de cada nova geração? Como é possível pensar a educação de modo que 
ela não seja concebida como um instrumento da política, um meio para a construção de um mundo novo que ainda não é e que só pode vir a ser, paradoxalmente, pela destruição da novidade que vem ao mundo a cada nascimento? Com base no pensamento de Hannah Arendt, pode-se afirmar que é preciso pensar a atividade da educação a partir da condição humana.

Pertence à própria natureza da condição humana o fato de que cada geração se transforma em um mundo antigo, de tal modo que preparar uma nova geração para um mundo novo só pode significar o desejo de arrancar das mãos dos recém chegados sua própria oportunidade face ao novo (ARENDT, 2013, p. 226).

À luz da análise arendtiana da condição humana, o problema da educação aponta para nossa atitude face ao fato da natalidade, pois, para Arendt (2013, p. 233, itálico da autora), “[...] a essência da educação é a natalidade, o fato de que seres nascem para o mundo". Ao assumirmos a responsabilidade pela educação dos mais novos, assumimos a dupla responsabilidade de proteger e abrigar um mundo de coisas que possuímos em comum com aqueles que vieram antes e com aqueles que virão depois de nós e, ao mesmo tempo, de conservar a novidade que vem ao mundo a cada nascimento (ARENDT, 2013). É nesse sentido que, para Arendt (2013), a atividade da educação é essencialmente conservadora, pois nossa atitude face ao fato da natalidade deve conservar o que é novo e revolucionário em cada criança que vem ao mundo. Dessarte, para que um mundo que já está fora do eixo possa ser posto em ordem de modo novo, a atividade da educação deve reconhecer sua própria fragilidade diante dos problemas que emergem das experiências políticas de nosso mundo. Se quisermos transformar o mundo, é preciso começar pela política, e não pela educação. Poderíamos dizer que toda tentativa de pôr fim aos nossos problemas políticos por meio da educação pressupõe, implícita ou explicitamente, a tentativa de controlar o modo como os recém chegados devem nascer para o mundo a fim de que supostamente, no futuro, ele seja posto em ordem. E, nesse caso, a atividade da educação corre o risco de destruir a novidade que vem ao mundo a cada nascimento, tornando-se um instrumento de alguma utopia política.

\footnotetext{
Nossa esperança está pendente sempre do novo que cada nova geração aporta; precisamente por basearmos nossa esperança apenas nisso, porém, é que tudo destruímos se tentarmos controlar os novos de tal modo que nós, os velhos, possamos ditar sua aparência futura (ARENDT, 2013, p. 243).
}

Dessa maneira, na qualidade de educadores ou de professores, se somos vistos no âmbito da escola, a única resposta que podemos dar aos problemas políticos de nosso tempo consiste em apresentar aos mais novos as obras e os monumentos do passado e, diante desses objetos culturais que julgamos dignos de permanecer no tempo, demonstrar nosso amor pelo 
mundo de coisas que possuímos em comum. Ao aparecer por iniciativa própria diante dos mais novos como representantes de um mundo velho, temos a oportunidade de transmitir aos mais novos os fragmentos de diversas tradições culturais do passado (RICOEUR, 1975). Contudo, para que seja possível transpor (transmittere) do passado para o presente os objetos culturais que nos foram legados por nossos antepassados, por homens e mulheres que apareceram e desapareceram antes de nossa chegada ao mundo, é preciso julgar quais obras e monumentos, quais enredos e personagens são dignos de ser lembrados pelas novas gerações. Uma vez que o fio que nos guiava pelos vastos domínios do passado, conforme Arendt (2013), está rompido, devemos lançar mão do exercício de nossa faculdade de julgar, pois é dessa forma que nós, os velhos, podemos compartilhar com os recém chegados um mundo de coisas que possuímos em comum. Assim, indicamos o lugar de onde vemos o mundo, de como ele nos parece, e revelamos aos novos quem somos.

Por outro lado, para aqueles que acabam de chegar no mundo, o problema da educação consiste fundamentalmente em responder à questão que se faz a todo recém chegado, a saber, quem és? (ARENDT, 2015) De acordo com a análise arendtiana da condição humana, somos inseridos pelo nascimento em um mundo velho como seres humanos novos e em processo de vir a ser; chegamos ao mundo como seres estranhos e, se somos vistos a partir do mundo, aparecemos como estrangeiros (ARENDT, 2013, 2005). À medida que nos familiarizamos paulatinamente com as coisas ao nosso redor, nascemos para o mundo como seres únicos e distintos. E na medida em que podemos aparecer por iniciativa própria no mundo, revelamos ativamente nossas identidades pessoais únicas (ARENDT, 2015). Se, pelo nascimento, somos inseridos em um mundo velho e comum, de que modo a atividade da educação pode criar condições para que um ser humano novo e em processo de vir a ser revele sua identidade pessoal única? Ou ainda, mais precisamente, qual o papel da educação na constituição de um alguém; no processo através do qual um ser humano se torna uma pessoa? Ainda que não seja possível dar uma resposta definitiva para essas perguntas, pode-se dizer que elas deram o piparote inicial para o movimento do pensamento; foram o ponto de partida para a experiência de como pensar a educação em um mundo que está fora do eixo.

Assumimos com Arendt (1961, p. 14, tradução nossa; 2013, p. 41) a convicção de “[...] que o pensamento ele mesmo emerge de incidentes da experiência vivida e deve permanecer limitado a eles como os únicos marcadores pelos quais estabelece suas coordenadas". Os ensaios a seguir são o resultado dessa experiência em como pensar metodicamente sem método, nas palavras de Theodor Adorno (2003), como se caminhássemos sem seguir um caminho preestabelecido, mas que se abre à medida que se caminha. Para Adorno (2003, p. 29-30): 
Nessa experiência, os conceitos não formam um continuum de operações, o pensamento não avança em um sentido único; em vez disso, os vários momentos se entrelaçam num tapete. Da densidade dessa tessitura depende a fecundidade dos pensamentos. O pensador, na verdade, nem sequer pensa, mas sim faz de si o palco da experiência intelectual, sem desemaranhá-la.

No primeiro ensaio, buscamos pensar, à luz da interpretação de Paul Ricoeur, o lugar das reflexões sobre a atividade da educação no pensamento de Hannah Arendt. Inicialmente, Paul Ricoeur se encontrava entre os comentadores da obra arendtiana, mas, ao longo dessa experiência em como pensar a educação em um mundo fora do eixo, tornou-se, ao lado de Arendt, um dos autores de referência. Veremos como a atividade da educação pode ser lida como uma resposta específica a uma questão específica colocada por nossa condição temporal de seres mortais e, nesse sentido, conforme a interpretação de Ricoeur (2016), de que modo poderíamos pensar em uma antropologia filosófica para a educação. No segundo ensaio, tentamos pensar como nós, os mais velhos, e os recém chegados no mundo nos constituímos narrativamente como um alguém no âmbito da educação. Ainda que, conforme Arendt (2013), a educação não possa desempenhar nenhum papel na política, veremos que papel ela pode desempenhar no processo de constituição de um alguém. Nesse ensaio, os quadros de referência conceituais de Paul Ricoeur e de Hannah Arendt se entrelaçam num tapete cujos fios não poderiam ser desemaranhados sem desfazer sua própria tessitura. E, por fim, no último ensaio, buscamos pensar sob quais condições a escola pode se tornar um lugar adequado para educação em um mundo fora do eixo. Com base em suas relações simbólicas fundamentais, segundo Jacques Rancière (1988), veremos como é possível pôr em ato a potência da escola. 


\section{UMA ANTROPOLOGIA FILOSÓFICA PARA A EDUCAÇÃO} A questão da essência nasce de uma pergunta formulada nos
seguintes termos: 'o que é X?', por exemplo, o que é a
coragem? O que é a virtude?

Paul Ricoeur. Ser, essência e substância em Platão e Aristóteles

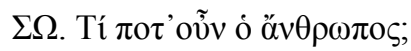

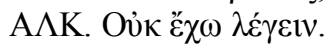

Sócrates: O que é então o homem? Alcibíades: Não tenho o que dizer.

Platão. Alcibiades I

Diante da obra monumental de Hannah Arendt, encontramos apenas um pequeno ensaio dedicado especificamente ao problema da educação. Publicado originalmente no periódico Partisan Review, em 1958, o ensaio A crise na educação poderia ser visto, por um leitor apressado, como um desvio fortuito no projeto filosófico arendtiano. Em uma leitura mais atenta, logo percebemos que esse ensaio pressupõe do leitor certa familiaridade com o quadro de referência conceitual da autora. E, à luz da interpretação de Paul Ricoeur (2016), torna-se evidente que as considerações arendtianas sobre a educação se entrelaçam às linhas fundamentais de seu pensamento político. Nesse capítulo, buscaremos mostrar de que maneira o problema da educação no mundo moderno está relacionado com a questão deixada em aberto em Origens do Totalitarismo, a qual, conforme a interpretação de Ricoeur (2016), Arendt teria buscado responder quase uma década depois em A Condição Humana. Em outras palavras, em um mundo no qual as soluções totalitárias parecem de fato ter sobrevivido à queda dos regimes totalitários, buscaremos pensar sob quais condições é possível realizar a tarefa da educação. Primeiro, faremos uma breve exposição da interpretação de Paul Ricoeur, a qual aponta para o sentido político do pensamento arendtiano. Em seguida, com base na interpretação de Marc Le Ny (2013), colocaremos uma objeção contra a leitura de Ricoeur, segundo a qual $A$ Condição Humana pode ser lida como uma antropologia filosófica; como um gênero de meditação que busca identificar os traços perduráveis da condição humana que podem resistir às vicissitudes do mundo moderno (RICOEUR, 2016). E, por fim, buscaremos explicitar as consequências da interpretação de Ricoeur para a atividade da educação. 


\subsection{A interpretação de Paul Ricoeur}

No Prefácio da segunda edição francesa de A Condição Humana, publicada em 1983, sob o título de Condition de l'homme moderne, Paul Ricoeur (2016) busca interpretar o hiato entre as duas obras que deram a Hannah Arendt sua fama e seu reconhecimento como pensadora política. Contra a perplexidade das interpretações que viam nesse hiato nada mais que "[...] uma mudança de registro inexplicável [...]”, em sua hipótese de leitura, Ricoeur (2016, p. 05, tradução nossa) sustenta que há uma relação fundamental entre Origens do Totalitarismo e $A$ Condição Humana. O ponto chave dessa interpretação está no fato de que ela busca tecer o fio que torna possível vincular essas duas obras que, tanto do ponto de vista temático quanto metodológico, são bastante distintas. Nesse sentido, pode-se afirmar que, para Ricoeur (2016), a linha mestra do projeto filosófico arendtiano consiste em pensar, por um lado, quais foram as condições de possibilidade para o surgimento dos movimentos e regimes totalitários e, por outro, sob quais condições é possível edificar um mundo não totalitário.

Em primeiro lugar, conforme Ricoeur (2016, p. 08-09, itálico do autor, tradução nossa), é preciso não negligenciar “[...] o caráter próprio do pensamento político que se exprime aí [nesse suposto hiato], seu percurso essencialmente problemático [...]", isto é, a tarefa de compreender uma realidade absolutamente nova a partir de categorias que nos foram legadas por uma tradição de pensamento político que, para tanto, mostra-se insuficiente. E aqui é oportuno lembrar que, segundo Arendt (2012, p. 12), compreender não significava descrever um fenômeno por meio de procedimentos analógicos e genéricos; muito menos negar a infâmia do que havia acontecido, como se tudo não tivesse passado de um pesadelo da razão esclarecida, mas antes tem a ver com "[...] encarar a realidade sem preconceitos e com atenção, e resistir a ela - qualquer que seja". É, por isso que, segundo a interpretação de Ricoeur, Arendt teria se voltado para os elementos que se cristalizaram nessa nova realidade; para as origens do totalitarismo, buscando compreender os acontecimentos políticos que marcaram profundamente o seu tempo ${ }^{1}$.

\footnotetext{
${ }^{1}$ Em Cristalli de storia: tra abisso ed redenzione, Olivia Guaraldo (1999) identifica alguns pontos de aproximação entre os projetos filosóficos de Hannah Arendt e Walter Benjamin, entre os quais gostaria de destacar a noção de descontinuidade da história. Com base nessa noção, cabe ao historiador a tarefa de recolher os acontecimentos do passado que, no tempo do agora, aparecem como fragmentos. "O agora, Jetztzeit, e a intensidade de um presente empenhado no reencontro fragmentário dos fenômenos passados, os quais, próprio no seu intento de redenção dos mesmos, se atualizam em ação. O fundamento de tais ações históricas está inteiramente na distância que existe entre a história entendida como desenvolvimento, como progresso, e a história como salvação ou como redenção. E a distância se mede por sua capacidade política, então ativa, da história (GAGNEBIN, 1978, p. 102). Eis porque a gestualidade insistente na suspensão da continuidade, gestualidade que é comum a Arendt e Benjamin, é antes de tudo incitamento à ação, empenho ético e político nos confrontos de uma realidade que clama por justiça" (GUARALDO, 1999, p. 63, itálico da autora, tradução nossa).
} 
Cabe nos perguntar, então, de que maneira nossa pensadora política buscou compreender, em seu projeto filosófico, o surgimento dos movimentos e regimes totalitários. Segundo Arendt (2012), o totalitarismo deve ser considerado como um acontecimento absolutamente novo. Ou seja, o fenômeno totalitário não poderia ser compreendido por meio de analogias ou comparações genéricas que nos remetessem à alguma experiência política do passado (ARENDT, 2012). Tão pouco poderia ser explicado à luz de teorias deterministas, pois, no projeto filosófico arendtiano, como destaca Newton Bignotto (2001, p. 42), o totalitarismo "[...] advém da condição criadora do homem, de sua capacidade de inventar novas ordens e instaurar novas formas de organização da vida em comum”. Contudo, continua Bignotto (2001, p. 42), não se pode afirmar que o fenômeno totalitário seja “[...] uma decorrência direta do exercício da liberdade humana [...]”, visto que, para Arendt (2008, p. 347), “[...] o totalitarismo é a negação mais radical da liberdade". Isso significa, conforme Bignotto (2001, p. 42), que o fenômeno totalitário surge precisamente da "[...] indeterminação fundamental de nossa condição e, por isso, não pode ser afastado definitivamente do horizonte humano".

A análise arendtiana do totalitarismo vai mostrar que os movimentos e regimes totalitários surgiram a partir de uma constelação histórica específica e, ainda que seus elementos possam não ter desaparecido completamente após a derrocada do nazismo e do estalinismo, eles jamais podem se repetir tal qual se cristalizaram no passado. Inscritos na ordem da contingência, como tudo aquilo que pertence ao domínio dos assuntos humanos, os movimentos e regimes totalitários não podem ser explicados, à luz do pensamento de Arendt, por uma mera descrição e concatenação de elementos que se amalgamaram em uma dada conjuntura histórica. Se assim o fosse, seria possível identificar tais elementos no presente - o que seria absolutamente possível nos dias de hoje - para vislumbrar, em um futuro próximo, o ressurgimento de sistemas totalitários, como se eles resultassem necessariamente da presença e articulação desses elementos. "Nada mais distante, no entanto, da maneira como nossa pensadora compreendia a tarefa do pensador político e a natureza do totalitarismo" (BIGNOTTO, 2001, p. 41).

Se, para Arendt, nossas categorias de pensamento se mostravam insuficientes para compreender o surgimento do totalitarismo, como é possível pensar, por exemplo, a experiência dos campos de concentração? Ao reconhecer a singularidade desse evento político, Arendt buscou encarar essa realidade sem preconceitos e com atenção, a fim de não confundir o fenômeno totalitário com nenhuma das experiências políticas do passado. Pois, para Arendt, não se pode reconhecer a singularidade de um evento sem fazer distinções. Ao contrário das interpretações que buscavam explicar o totalitarismo por meio de analogias e comparações, 
Arendt (2012) insiste no fato de que era preciso distinguir conceitualmente os regimes totalitários de toda sorte de ditaduras e tiranias que existiram no passado. Ainda que o medo e a violência estivessem presentes em todos eles, o traço distintivo dos sistemas totalitários apontava para o uso da ideologia e do terror como elementos centrais dessa nova forma de dominação. Nesse sentido, de acordo com Adriano Correia (2014, p. xxi), para pensar conceitualmente as condições para o surgimento de um fenômeno sem precedentes, é preciso identificar a novidade que o caracteriza, de modo que "[...] o pensamento tem de operar antes por esclarecimento via distinção que por análise via associação".

Nesse sentido, é fundamental não perder de vista que o pensamento político de Arendt parte "[...] da contingência do evento à irrupção do conceito" (RICOEUR, 2016, p. 11, tradução nossa). Poderíamos dizer que o conceito de totalitarismo é forjado por Arendt a fim de compreender como foi possível a invenção de um mundo fictício ${ }^{2}$ no qual a realidade é substituída pela coerência interna dos elementos que sustentavam a lógica de uma ideia. "A ideologia trata o curso dos acontecimentos como se seguisse a mesma 'lei' adotada na exposição lógica da sua “ideia"” (ARENDT, 2012, p. 624). Isso permitiu aos regimes totalitários implementar um gigantesco aparelho de terror, os campos de concentração e extermínio, no qual os seres humanos podiam ser submetidos integralmente às supostas leis da Natureza, no caso do nazismo, e às supostas leis da História, no caso do estalinismo. "Vistos através do prisma da ideologia, os campos parecem até ser lógicos demais" (ARENDT, 2012, p. 606). Esse mundo fictício, como mostrou as análises de Hannah Arendt (2012), pressupunha a hipótese monstruosa de que tudo é possivel. E, conforme a interpretação de Ricoeur (2016), é precisamente deste ponto que se pode entender a relação entre Origens do Totalitarismo e $A$ Condição Humana: se o horror e a infâmia dos sistemas totalitários partem da premissa de que

\footnotetext{
2 Para Arendt (2012), um mundo fictício, um mundo que é organizado com base em um único ponto de vista, só pode surgir quando o mundo comum foi completamente destruído. "O mundo comum acaba quando é visto somente sob um aspecto e só se lhe permite apresentar-se em uma única perspectiva" (ARENDT, 2015, p. 71). Os regimes totalitários são mundos fictícios na medida em que eles foram estruturados ideologicamente para verificar suas premissas que jamais poderiam resistir à condição humana da pluralidade. A destruição do espaço no qual os seres humanos podem se reunir e compartilhar o mundo foi uma das condições de possibilidade para a existência de um mundo fictício. Mais precisamente, conforme a análise arendtiana do fenômeno totalitário, o que garante a existência de um mundo fictício não é simplesmente o fato de que ele é estruturado por uma ideologia na qual tudo é possível, mas que a lógica dessa ideia pode ser verificada em laboratórios cientificamente controlados, os campos de concentração e extermínio, onde se podia confirmar a validade de suas premissas fundamentais. E, para isso, segundo Arendt (2012), os regimes totalitários lançavam mão não apenas do uso da força e da violência, como ocorre em qualquer tirania ou ditadura, mas do terror. Para Arendt (2012), o terror é a essência do totalitarismo. "Em lugar das fronteiras e dos canais de comunicação entre os homens individuais, [o terror] constrói um cinturão de ferro que os cinge de tal forma que é como se a pluralidade se dissolvesse em Um-Só-Homem de dimensões gigantescas" (ARENDT, 2012, p. 619).
} 
tudo é possível, é preciso, percorrendo o caminho inverso, se perguntar quais são os obstáculos para a verificação dessa hipótese monstruosa.

Ora, se os campos de concentração e extermínio surgiram nesse mundo fictício criado pelos sistemas totalitários, servindo de laboratórios cientificamente controlados para fazer experimentos e modificar a natureza humana, conforme Arendt (2012), é preciso se perguntar agora em quais condições é possível edificar um mundo não totalitário. Em outras palavras, "[...] em quais condições um mundo não concentracionário é possível? Segundo quais pressupostos o homem deixa de ser supérfluo?” (RICOEUR, 2016, p. 14, tradução nossa) Na interpretação de Ricoeur, essas são as perguntas que orientaram a nova investigação de Arendt em A Condição Humana. É por isso que, de acordo com Ricoeur (2016, p. 14, tradução nossa), essa obra deve ser lida "[...] como o livro da resistência e da reconstrução".

À luz dessa interpretação, é possível entender a mudança no modo como Arendt buscou compreender o fenômeno totalitário. Se, em Origens do Totalitarismo, Arendt mostrou como o racismo, o antissemitismo e o imperialismo se cristalizaram e tornaram possível o surgimento dos sistemas totalitários, é somente em A Condição Humana que a autora vai pensar sob quais condições se pode erigir um mundo não totalitário. Para Ricoeur (2016), essa é a questão fundamental que foi deixada em aberto por Arendt em sua primeira grande obra. "Tendo ficado pendente essas implicações propriamente políticas [em Origens do Totalitarismo]”, observa Ricoeur (2016, p.14, tradução nossa), a nova investigação de Arendt precisa ser entendida e julgada no mesmo plano em que foi realizada pela autora. Nesse sentido, para Ricoeur (2016, p. 15, itálico do autor, tradução nossa), A Condição Humana pode ser lida como uma antropologia filosófica, isto é, “[...] uma investigação que visa identificar os traços mais duráveis da condição humana, aqueles que são menos vulneráveis às vicissitudes da era moderna". Essa hipótese de leitura busca enfatizar os traços temporais da análise das atividades em que os seres humanos se encontram ativamente engajados no mundo. Ou seja, a interpretação do filósofo francês enfatiza, portanto, o aspecto temporal da análise arendtiana, sem negligenciar a centralidade do espaço no pensamento de Hannah Arendt (RICOEUR, 2016). De acordo com José Sérgio Carvalho (2019), essa ênfase sustentada por Ricoeur em sua interpretação do pensamento político de Arendt encontra respaldo nas últimas linhas do Prólogo de A Condição Humana, visto que, segundo Arendt (2015, p. 07), um de seus objetivos nessa nova investigação era o de analisar aquelas “[...] capacidades humanas gerais que provém da condição humana e são permanentes, isto é, que não podem ser irremediavelmente perdidas enquanto não mudar a própria condição humana". 
Nesse sentido, conforme a interpretação de Ricoeur (2016), pode-se afirmar que a nova investigação levada a cabo por Arendt em A Condição Humana mantém um laço de filiação (lien de filiation) com sua primeira grande obra. Para Ricoeur (2016, p. 15, tradução nossa), essa mudança de plano foi necessária para resolver a questão deixada em aberto em Origens do Totalitarismo; para resolver o que se poderia chamar, conforme a interpretação do filósofo francês, de "[...] o impasse epistemológico de Origens do Totalitarismo". Esse impasse apontava para o paradoxo no qual os sistemas totalitários só podiam verificar suas premissas por meio dos campos de concentração e extermínio. Ou seja, a hipótese totalitária segundo a qual se podia modificar a natureza do homem dependia da instalação de um gigantesco aparelho de terror; da construção de laboratórios cientificamente controlados para verificar a superfluidade dos seres humanos. Portanto, segundo a interpretação de Ricoeur (2016), podese afirmar que, perplexa diante desse impasse epistemológico em que, sob certas condições, tudo é permitido, tudo é possivel, Arendt buscou estabelecer as linhas fundamentais de sua nova investigação a partir de um plano ético-político. É nesse sentido que $A$ Condição Humana pode ser lida, conforme Ricoeur (2016), como uma obra de resistência e de reconstrução, pois as análises arendtianas apontam para as condições segundo as quais é possível reconstruir o espaço de aparência no qual cada um, mediante atos e palavras, pode exprimir sua distinção única e, desse modo, resistir à tentativa totalitária de tornar supérfluos os seres humanos. É desse impasse, colocado a partir de um plano epistemológico em Origens do Totalitarismo, que Arendt teria extraído um critério filosófico para realizar sua nova investigação a partir, agora, de um plano ético-político (RICOEUR, 2016). Esse critério, segundo Ricoeur (2016, p. 15, itálico do autor, tradução nossa):

[...] corresponde exatamente à questão deixada sem resposta dez anos antes: sob qual condição um universo não totalitário é possível? Se a hipótese totalitária é aquela da ausência de estabilidade da natureza humana, aquela da possibilidade de mudar a natureza humana, o critério mais apropriado para a nova pesquisa $[\mathrm{em} A$ Condição humana] deve consistir em uma avaliação das diferentes atividades humanas do ponto de vista temporal de sua durabilidade.

Cônscio do perigo de uma interpretação que, ao invés de destacar a crítica da modernidade como a principal contribuição de Arendt ao pensamento contemporâneo, põe o acento no que se poderia chamar de "[...] o caráter trans-histórico das análises de $A$ Condição Humana [...]”, Ricoeur (2016, p. 15, tradução nossa) nos oferece ainda mais um argumento para sustentar sua hipótese de leitura. Para o filósofo francês, sua interpretação pode ser sustentada a partir da própria composição da obra arendtiana. Segundo Ricoeur (2016, p. 15, tradução nossa), o fato de que, “[...] a despeito de suas repetidas incursões no problema da modernidade 
nos primeiros cinco capítulos [...]", a autora tenha dedicado um sexto e último capítulo em $A$ Condição Humana, vinculando explicitamente a análise da vita activa e a era moderna, justificaria uma leitura que buscasse enfatizar o aspecto temporal da nova investigação arendtiana.

Do ponto de vista da composição de $A$ Condição Humana, observa Ricoeur (2016, p. 16, tradução nossa), a distinção entre vita activa e vita contemplativa é "[...] a pressuposição implícita de toda a obra, que não será abordada de frente senão em sua obra póstuma e inacabada A vida do espírito". Assim, para Ricoeur, a essa distinção estão subordinadas as demais distinções fundamentais de $A$ Condição Humana, a saber, a distinção entre domínio público e domínio privado; e a distinção entre trabalho, obra e ação. Segundo Ricoeur (2016, p. 16, tradução nossa), essas três categorias que correspondem aos capítulos centrais de $A$ condição humana não devem ser entendidas no sentido kantiano, isto é, como “[...] estruturas a-históricas do espírito". Ou seja, essas categorias não devem ser entendidas como conceitos puros do entendimento, mas antes como estruturas históricas que, “[...] ao longo de suas múltiplas mutações, conservam um tipo de identidade flexível que autoriza a designá-las como traços perduráveis da condição humana" (RICOEUR, p. 16, itálico do autor, tradução nossa). Assim, pode-se afirmar, conforme a interpretação de Ricoeur, que a antropologia filosófica de Arendt se organiza com base na distinção entre trabalho, obra e ação, por meio da qual os traços mais duráveis da condição humana podem ser explicitados com vista a resistir à tentação totalitária.

Para os nossos propósitos, gostaríamos de destacar dois pontos dessa interpretação. $\mathrm{O}$ primeiro é o de que a relação estabelecida por Ricoeur entre Origens do Totalitarismo e $A$ Condição Humana se apoia fundamentalmente na tentativa de compreender o fenômeno totalitário, no diálogo interminável com a essência do totalitarismo (ARENDT, 2008). Nesse sentido, poderíamos dizer que a necessidade da compreensão é o fio vermelho que torna possível o laço entre essas duas obras que, de modos distintos, buscam pensar a experiência do totalitarismo. Segundo Arendt (2008, p. 330):

A compreensão, diferentemente da informação correta e do conhecimento científico, é um processo complexo que nunca gera resultados inequívocos. É uma atividade interminável por meio da qual, em constante mudança e variação, chegamos a um acordo e a uma reconciliação com a realidade ${ }^{3}$, isto é, tentamos sentir o mundo como nossa casa.

\footnotetext{
${ }^{3}$ No ensaio O conceito de história - antigo e moderno, Arendt (2013) emprega a mesma expressão para se referir ao efeito catártico no episódio da Odisseia (Canto VIII), no qual o herói, ao ouvir o canto do aedo na corte dos feácios acerca de seus ditos e feitos, oculta seu rosto e chora lágrimas da recordação. "A cena em que Ulisses escuta a estória de sua própria vida é paradigmática tanto para a História como para a Poesia; a 'reconciliação com a realidade', a catarse, que segundo Aristóteles era a própria essência da tragédia, constituía o objetivo último da História, alcançado através das lágrimas da recordação" (ARENDT, 2013, p. 74-75). Se, para Aristóteles (1449),
} 
Se, conforme a interpretação de Ricoeur, a nova investigação arendtiana em $A$ Condição Humana buscou resolver, no plano ético-político, o impasse que estava colocado no plano epistemológico em Origens do Totalitarismo, essa mudança pode ser explicada pela tentativa de compreender o fenômeno totalitário. É notável que, para Arendt, o inacabamento da atividade da compreensão e sua decorrente impossibilidade de fornecer uma explicação definitiva para o fenômeno totalitário não devem ser considerados como uma inconsistência, mas antes como uma abertura para a experiência do pensamento. Ainda que a compreensão nunca gere resultados inequívocos, esse processo complexo por meio do qual tentamos sentir o mundo como nossa casa permite que "[...] os homens ativos (e não os homens que se dedicam a contemplar algum curso histórico progressivo ou fadado à decadência) finalmente vêm a aceitar o que aconteceu de maneira irrevogável e a se reconciliar com o que existe de modo inevitável" (ARENDT, 2008, p. 345). É nesse sentido que, para Arendt (2008), a compreensão se torna o outro lado da ação. Como se a atividade da compreensão fosse capaz de fazer renascer a fé e a esperança na capacidade humana de erigir um mundo não totalitário. No pensamento de Arendt, essa fé e essa esperança não devem ser confundidas com as virtudes teologais que são infundidas por Deus nos seres humanos. Em outras palavras, a fé e a esperança estão vinculadas à condição humana da natalidade, na qual "[...] a faculdade da ação se radica ontologicamente" (ARENDT, 2015, p. 306). Poderíamos dizer que compreender o que passou a existir inexoravelmente entre nós aumenta nossa potência de agir, e que nos reconciliar com a realidade permite expurgar os afetos reativos que estão na base do ressentimento. Para Arendt, a fé e a esperança repousam no fato de que o mundo estaria condenado a ruína se não fosse a chegada de novos seres humanos, se não fosse a nossa capacidade de iniciar algo novo, isto é, de agir. Assim, conforme a interpretação de Ricoeur (2016, p. 13, itálico do autor), pode-se afirmar que, com base na fé e na esperança de que a cada nascimento um mundo novo em potencial vem a existir, a análise arendtiana da condição humana aponta para a possibilidade de que um mundo não totalitário venha a existir através de nossa “[...] capacidade de abrir, de preservar ou de reconstruir um espaço político".

Se, para Arendt (2008), a compreensão se torna o outro lado da ação, a abertura, a preservação ou a reconstrução do espaço político requer não apenas o exercício de nossa

a кá $\theta \alpha \rho \sigma ı \varsigma$ se dava por intermédio de personae dramatis, e não simplesmente por uma narrativa e era suscitada pela piedade e pelo medo levando a cabo a depuração de tais afetos; para Arendt (2013), a reificação de seus ditos e feitos, o encadeamento de suas dores e seus sofrimentos em uma narrativa é o que torna possível a reconciliação de Ulisses com a realidade, isto é, com aquilo que passou a existir não apenas subjetivamente para o herói, mas objetivamente para todos os ouvintes. Nesse sentido, poderíamos dizer que, para Arendt, há um elemento catártico na compreensão, o qual precisamente torna possível uma reconciliação com a realidade - mesmo depois da ocorrência daquilo que jamais poderia ter ocorrido. 
capacidade de agir, mas também de nossa faculdade de imaginar. Segundo Arendt (2008, p. 346):

\begin{abstract}
Somente a imaginação permite que enxerguemos as coisas em sua perspectiva adequada, que tenhamos forças suficientes para afastar o que está demasiado próximo, a fim de conseguir ver e compreender sem distorções nem preconceitos, que tenhamos generosidade suficiente para transpor abismos de lonjuras, a fim de conseguir ver e compreender, como se fosse uma questão pessoal nossa, tudo o que está demasiado distante de nós. Esse distanciamento de algumas coisas e avizinhamento de outras faz parte do diálogo da compreensão, pois para suas finalidades, a experiência direta envolve um contato próximo demais e o mero conhecimento ergue barreiras artificiais.
\end{abstract}

Assim, para que uma coisa ou um acontecimento que nos afeta diretamente possa ser compreendido, é preciso instaurar uma distância, um afastamento entre nós e aquilo que buscamos compreender. É, portanto, nesse jogo entre instaurar uma distância do que está demasiado próximo e transpor um abismo a fim de aproximar-se do que está demasiado longe que reside o interminável diálogo de Arendt com a essência do totalitarismo. Se, para Arendt (2008, p. 347), “[...] o totalitarismo é a negação mais radical da liberdade [...]”, poderíamos dizer que as obras Origens do Totalitarismo e A Condição Humana nos permitem ver e compreender o ocaso e a aurora da liberdade humana. É nesse sentido, conforme a interpretação de Ricoeur (2016), que Arendt teria buscado responder não apenas como foi possível o surgimento de um mundo totalitário, mas também sob quais condições é possível um mundo não totalitário. No projeto filosófico de Arendt, compreensão e ação estão inscritas no mesmo círculo hermenêutico.

Se, conforme Arendt (2008, p. 333), o compreender é uma atividade que busca um significado (meaning) ao que fazemos e ao que sofremos, "[...] o processo de compreensão também é, com toda evidência e talvez em primeiro lugar, um processo de autocompreensão". Isso porque a compreensão, de acordo com Arendt (2008), origina-se do próprio processo do viver. É por isso que a compreensão é um processo interminável, ou, mais precisamente, só termina com a nossa morte. Na medida em que o processo do compreender e o processo do viver concorrem lado a lado, o término da compreensão deve coincidir com o término de nossa própria vida (ARENDT, 2008).

E aqui gostaríamos de destacar o potencial educativo da compreensão. Uma vez que, através do nascimento, somos inseridos no mundo como estranhos, a educação pode ser vista como a atividade por meio da qual nos familiarizamos, primeiro, com as coisas que estão ao nosso redor e, depois, com os objetos materiais e simbólicos das heranças culturais do passado (ARENDT, 2013; RICOEUR, 1975). Desse modo, a educação torna possível uma apropriação 
não apenas dos objetos culturais que pertencem à nossa própria cultura, mas também propicia uma abertura para que os mais novos se apropriem à distância dos objetos que pertencem a outras tradições culturais do passado (RICOEUR, 1975). Esse processo lento e gradual no qual seres humanos novos e em processo de vir a ser vão se familiarizando com o que se passa no mundo e consigo mesmos está intimamente relacionado com o processo de compreensão, o qual é, com toda evidência e talvez em primeiro lugar, um processo de autocompreensão. Poderíamos afirmar, nesse sentido, ao longo do processo educativo, do processo de familiarização de crianças e jovens com os objetos culturais que constituem o nosso mundo comum, os mais novos vão compreendendo a si mesmos como seres únicos e igualmente distintos.

E o segundo ponto da interpretação de Ricoeur que gostaríamos de destacar é o de que ela nos permite ver em primeiro plano a dimensão temporal da análise arendtiana acerca da condição humana, a qual permite identificar os traços perduráveis que se manifestam ao longo do tempo nas diferentes atividades humanas. Ao invés de ler A Condição Humana como uma obra que busca tecer, antes de tudo, uma crítica da modernidade, destacando a análise histórica da moderna alienação do mundo, a interpretação de Paul Ricoeur (2016) vai enfatizar o caráter trans-histórico da análise arendtiana que busca explicitar aquelas "[...] capacidades humanas gerais que provêm da condição humana e são permanentes" (ARENDT, 2015, p. 07). Essa interpretação - e é preciso deixar isso bem claro! - não isola uma análise da outra, mas propõe, digamos, uma relação de figura e fundo entre elas, enfatizando a dimensão temporal das categorias da vita activa. Mas qual o propósito dessa ênfase na interpretação de Paul Ricoeur? Ela visa realçar o sentido político do pensamento de Arendt. E na medida em que a análise dos traços permanentes da condição humana, conforme a leitura de Ricoeur, opõe-se diametralmente à hipótese totalitária, é fundamental que esse sentido político do pensamento arendtiano seja explicitado.

Se o empreendimento totalitário consistia em destruir não apenas o espaço político, mas também em eliminar fundamentalmente a liberdade e a espontaneidade humanas por meio de um gigantesco aparelho de terror, “[...] o político enquanto tal é, aquém de sua perversão totalitária, um projeto de longa duração" (RICOEUR, 1995, p. 16). Assim, quanto mais nosso mundo for erigido sob o signo da mudança, como se alguma força ou lei de movimento agisse inexoravelmente sobre ele (pensemos, hoje, não mais na História ou na Natureza, mas no Mercado), maior será a urgência de não perdermos de vista aqueles traços mais duráveis das capacidades humanas que, segundo Arendt (2015, p. 07), “[...] não podem ser irremediavelmente perdidos enquanto não mudar a própria condição humana". Se, conforme a 
interpretação de Ricoeur (2016), Arendt buscou identificar, em sua obra de resistência e reconstrução, os traços mais duráveis de nossa condição humana a fim de responder sob quais condições é possível um mundo não totalitário, isso se deve ao fato de que, segundo Arendt (2012, p. 610):

As soluções totalitárias podem muito bem sobreviver à queda dos regimes totalitários sob a forma de forte tentação que surgirá sempre que pareça impossível aliviar a miséria política, social ou econômica de um modo digno do homem.

É, portanto, de um ponto de vista político que A Condição Humana pode ser lida, segundo a interpretação de Ricoeur, como uma antropologia filosófica, como um gênero de meditação que, diante das aporias da política, busca identificar os traços mais duráveis de nossas capacidades que provém da condição humana. Para Arendt (2013, 2013b), a política não é um atributo essencial do homem, no singular, mas um espaço que surge entre os seres humanos, no plural, mediante atos e palavras; um espaço que, em tempos sombrios, pode desaparecer, mas que potencialmente jamais deixa de existir.

\subsection{A objeção de Marc Le Ny}

Ainda que a hipótese de leitura defendida por Paul Ricoeur seja interessante para os nossos propósitos, é possível que ela seja interpretada como uma tentativa de ordenar a obra arendtiana dentro de um sistema de classificação baseado em gêneros filosóficos ou, mais precisamente, em gêneros de meditação. E sabemos quão inoportuno pode ser classificar o romance de Guimarães Rosa, Grande Sertão: Veredas, como uma obra do regionalismo, ou, o filme dirigido por Vittorio De Sica, Ladrões de Bicicletas, como uma obra do neorrealismo italiano. Embora Ricoeur utilize o termo "antropologia filosófica" em uma acepção bastante específica e delimitada, admitir que $A$ Condição Humana seja classificada como uma obra desse gênero de meditação significa reconhecer a possibilidade de identificar, no projeto filosófico de Arendt, certas temáticas que caracterizariam outras obras do mesmo gênero. Ou seja, se $A$ Condição Humana pode ser lida como uma antropologia filosófica, isto é, pode ser lida a partir de certas características que definem esse gênero de meditação, poderíamos supor a possibilidade de encontra na obra de Arendt as mesmas temáticas que encontramos, por exemplo, na obra de Max Scheler ou de Arnold Gehlen. Em outras palavras, ao classificar $A$ Condição Humana como uma obra de antropologia filosófica, abre-se a possibilidade - legítima - de vincular o pensamento de Arendt a determinadas questões sobre as quais ela jamais se colocou. 
Em Hannah Arendt: le temps politiques des hommes, Marc Le Ny (2013) defende a tese segundo a qual o tempo seria uma dimensão fundamental do pensamento arendtiano. Para Le Ny (2013), a originalidade do pensamento político de Arendt consistiria justamente em considerar essa dimensão impensada na filosofia política. A presença dessa dimensão temporal na compreensão dos fenômenos políticos não implica, conforme Le Ny (2013), uma investigação acerca do que é o tempo ou de como se constitui subjetivamente uma consciência do tempo. "Para Arendt, trata-se de pensar a realidade humana e os fenômenos políticos sob o horizonte do tempo. Não pensar o tempo, mas pensar temporalmente a vida política” (LE NY, 2013, p. 40, tradução nossa). Na medida em que põe em relevo o aspecto temporal da análise arendtiana, poderíamos dizer que a interpretação de Marc Le Ny, nascida três décadas depois, possui um grau de parentesco com a interpretação de Paul Ricoeur. Não obstante a ênfase na dimensão temporal da análise arendtiana, para Le Ny, seria um disparate ler $A$ Condição Humana, ou qualquer outra obra de Arendt, como uma antropologia filosófica. Segundo Le Ny (2013, p. 81, tradução nossa):

\begin{abstract}
Arendt renuncia ao que se chama de uma antropologia filosófica. Falar de uma antropologia arendtiana a propósito de $A$ Condição Humana e $A$ Vida do Espírito aparece como um contrassenso. $\mathrm{O}$ pensamento arendtiano tem explicitamente o objetivo de apreender a condição humana, o que o afasta de qualquer antropologia.
\end{abstract}

Esse contrassenso ao qual se refere Marc Le Ny (2013) repousaria na tentativa de classificar a obra arendtiana com base no gênero de meditação inaugurado por Max Scheler (1874-1928). Em nota, Le Ny (2013) observa que essa corrente de pensamento que vicejou na paisagem intelectual alemã dos anos de 1920 e 1930, chamada de antropologia filosófica, buscava delimitar, tanto nas ciências biológicas quanto nas ciências humanas, o que caracterizava a espécie humana em relação ao reino mineral, vegetal e animal. À luz da antropologia filosófica de Max Scheler, o ser humano passou a ser visto como uma unidade psicofísica, em oposição crítica ao dualismo e ao idealismo filosófico (LE NY, 2013). Por isso, Marc Le Ny (2013) não admite em hipótese alguma aproximar o pensamento de Arendt daquilo que se chama de uma antropologia filosófica.

Para Le Ny (2013), se a noção de natureza está fora do quadro de referência conceitual de Arendt, então seria um equívoco interpretar a investigação acerca da condição humana de um ponto de vista antropológico. Assim, conforme a interpretação de Le Ny (2013), deve-se afastar o pensamento de Arendt não apenas desse gênero específico de meditação, a antropologia filosófica, mas de toda antropologia. O esforço empreendido na análise da condição humana deve antes ser entendido na chave de uma desconstrução das categorias 
metafísicas, levada a cabo pelo que Arendt (2000) chamou de técnica de desmantelamento (technique of dismantling). Segundo Marc Le Ny (2013), a investigação arendtiana realizada em $A$ Condição Humana deve ser lida, portanto, como uma análise existencial da condição humana. Ou seja, para Le Ny (2013, p. 81, tradução nossa), “[...] aquilo que é analisado por Arendt em termos de atividades é o que conduz a autora à apreensão das diferentes temporalidades da existência humana".

Tendo em vista essa objeção, em que sentido poderíamos ler A Condição Humana como uma antropologia filosófica, sem que essa interpretação seja levada ao tribunal da razão como uma prova de contrassenso? Poderíamos, com efeito, apelar para o direito concedido a Ricoeur de definir seus próprios termos - o que nos permitiria dar o próximo passo e explicitar as consequências dessa interpretação para a educação. Mas, nesse caso, correríamos o risco de condenar injustamente a leitura de Ricoeur. Pois, em recorrendo a esse direito, tornar-se-ia lícito o emprego de quaisquer termos para se referir a qualquer coisa. Ou seja, para que a interpretação de Ricoeur fosse absolvida da acusação de contrassenso, seria preciso alegar que os termos 'antropologia filosófica' foram definidos pelo filósofo francês dentro de seu próprio mundo de significado (ARENDT, 2013). Na maioria dessas discussões, segundo Arendt (2013, p. 132), há um consenso tácito:

[...] de que podemos ignorar as distinções e proceder baseados no pressuposto de qualquer coisa pode, eventualmente, ser chamada de qualquer outra coisa e de que as distinções somente têm significado na medida em que cada um de nós tem o direito de 'definir seus termos'.

É evidente que não se trata aqui de uma questão meramente terminológica. O que está em jogo nesse conflito de interpretações é o tipo de ligação que se pode estabelecer entre as obras de Arendt. Para Ricoeur (2016), em Origens do totalitarismo, Arendt teria colocado em termos epistemológicos a questão sobre as condições de possibilidade do totalitarismo, isto é, a questão de como foi possível o surgimento dos movimentos e regimes totalitários. A leitura de Ricoeur sustenta, nesse sentido, que existe um vínculo essencial entre a análise histórica do totalitarismo, dos elementos que se cristalizaram no fenômeno totalitário, e a análise temporal dos traços mais duráveis da condição humana. Assim, pode-se afirmar que, para Ricoeur, esse gênero de meditação teria fornecido as regras de composição para Arendt empreender uma nova investigação capaz de refutar, de um ponto de vista político, a hipótese totalitária que, como vimos, postulava a possibilidade de fabricar um tipo de ser humano que jamais poderia existir senão no interior dos campos de concentração e de extermínio. Segundo Arendt (2012, p. 582): 


\begin{abstract}
Os campos destinam-se não apenas a exterminar pessoas e degradar seres humanos, mas também servem à chocante experiência da eliminação, em condições cientificamente controladas, da própria espontaneidade como expressão da conduta humana, e da transformação da personalidade humana numa simples coisa, em algo que nem mesmo os animais são; pois o cão de Pavlov que, como sabemos, era treinado para comer quando tocava um sino, mesmo que não tivesse fome, era um animal degenerado.
\end{abstract}

Diante desse paradoxo constitutivo dos regimes totalitários, a saída arendtiana foi então empreender "[...] uma nova modalidade de antropologia filosófica [...]", nas palavras de José Sérgio Carvalho (2018, p. 262). Seria, de fato, um contrassenso interpretar a obra de Arendt como se a autora tivesse se filiado a alguma corrente de pensamento que buscasse determinar a natureza do homem. Ocorre que, na interpretação de Ricoeur, a antropologia filosófica não é definida como uma investigação acerca da essência ou da natureza humana. Tal como Alcebíades no diálogo homônimo de Platão, a antropologia filosófica, na interpretação de Ricoeur, nada tem a dizer sobre $o$ que é o homem.

A objeção de Le Ny (2013) consistiria então na recusa de toda e qualquer interpretação que tentasse vincular a obra de Arendt à corrente de pensamento inaugurada por Max Scheler. No entanto, ainda que essa corrente de pensamento viesse a fornecer as regras canônicas para a composição desse gênero de meditação, ao ler A Condição Humana como uma antropologia filosófica, a interpretação de Ricoeur passa ao largo do problema colocado por Max Scheler, a saber, o de como determinar a estrutura essencial do ser humano. Para Max Scheler (1994), a antropologia filosófica é uma disciplina na qual tudo aquilo que pertence especificamente à espécie humana pode ser explicado a partir de uma nova imagem da estrutura essencial do homem. A investigação proposta por Max Scheler buscar explicar a linguagem, a consciência moral, o uso de ferramenta, a ideia de justiça, o Estado etc. com base na estrutura ontológica de um ser psicofísico que se distingue dos demais seres vivos por manifestar objetivamente um princípio que se opõe à vida em geral; um princípio que não se reduz à evolução da vida porque é antes o fundamento de todas as coisas (SCHELER, 1994). Esse princípio é o espírito e, na estrutura essencial do homem, segundo as análises de Max Scheler (1994), a categoria de pessoa é o centro ativo no qual esse fundamento de todas as coisas se manifesta. Scheler (1994) vai mostrar em sua antropologia filosófica que, na ontogênese da espécie humana, a manifestação do espírito no homem é concomitante à ideia de um ser suprassensível, infinito e absoluto. Portanto, esse fundamento metafísico que transcende a vida dos seres humanos na Terra é o principal argumento pelo qual poderíamos afirmar, conforme Le Ny (2013), que seria um contrassenso vincular a obra de Hannah Arendt à corrente de pensamento inaugurada por Max Scheler. No entanto, à luz da teoria narrativa de Ricoeur, como veremos mais adiante, uma obra 
singular pode se relacionar de diferentes modos com as regras que tradicionalmente foram estabelecidas para a composição de um determinado gênero.

Antes de considerar, pelo prisma das análises de Ricoeur, como uma obra singular pode se relacionar de diferentes modos com as regras canônicas de um gênero de meditação, gostaríamos de comentar brevemente a maneira como a noção de natureza humana aparece na obra de Arendt. Para tanto, não se pode perder de vista, conforme Ricoeur (2016), que o pensamento político de Arendt parte da contingência do evento à irrupção do conceito. A noção de natureza humana, como bem observou Marc Le Ny (2013), é absolutamente estranha ao quadro de referência conceitual de Arendt. Não se trata de um conceito ou uma categoria de análise que Arendt teria emprestado de uma tradição de pensamento para analisar "[...] a estrutura elementar da dominação e dos movimentos totalitários” (ARENDT, 2008. p. 419). Ainda que, ao longo de sua análise histórica do fenômeno totalitário, Arendt se refira à noção de natureza humana, isso não significava que ela tivesse levado a sério a pretensão do totalitarismo e admitido tacitamente a possibilidade de modificar a natureza do homem ${ }^{4}$ (ARENDT, 2008). No projeto filosófico de Arendt, essa noção deve ser interpretada à luz de uma trama conceitual que buscava compreender a essência do totalitarismo. Em outras palavras, a noção de natureza humana pode ser lida, no pensamento arendtiano, como uma premissa totalitária que a autora buscou reconstruir a fim de explicitar a lógica dos sistemas totalitários. Em regime de dominação total, a força coerciva do raciocínio totalitário é assegurada pelo terror que destrói o espaço entre os seres humanos e, por conseguinte, o espaço no qual a liberdade pode se manifestar. A análise arendtiana vai mostrar, portanto, que a lógica dos sistemas totalitários admitia como premissa a possibilidade de modificar a natureza humana nos campos de concentração e extermínio. Para Arendt (2012, p. 583), os campos são “[...] a verdadeira instituição central do poder organizacional totalitário”. Sem essa instituição, o domínio totalitário jamais teria se realizado. "Os campos de concentração e de extermínio dos regimes totalitários servem como laboratórios onde se demonstra a crença fundamental do totalitarismo de que tudo é possível” (ARENDT, 2012, p. 581). É neste sentido que a noção de natureza humana aparece na análise arendtiana do totalitarismo: ela permite mostrar como o sistema totalitário buscou reduzir a existência humana à mera vida, submetendo-a, por dedução lógica,

\footnotetext{
${ }^{4}$ Em Uma réplica a Eric Voegelin, Arendt (2008) se defende da acusação segundo a qual ela teria levado a sério a pretensão totalitária; de que, em regime de dominação total, seria possível modificar a natureza humana. Em Origens do totalitarismo, conforme a interpretação de Voegelin, Arendt teria admitido essa possibilidade ao se referir à tentativa totalitária de produzir em laboratórios cientificamente controlados o súdito ideal do regime totalitário. Para Voegelin, ao admitir a possibilidade de modificar a natureza humana, a interpretação arendtiana do sistema totalitário pode ser vista como um "[...] sintoma da derrocada intelectual da civilização ocidental". Ver Arendt (2008, p. 417-424).
} 
às leis de movimento que apontavam forçosamente para o envio do material humano para as fábricas de cadáveres e os poços de esquecimento ${ }^{5}$ (ARENDT, 2012, p. 609).

A experiência dos campos de concentração demonstra realmente que os seres humanos podem transformar-se em espécimes do animal humano, e que a 'natureza' do homem só é 'humana' na medida em que dá ao homem a possibilidade de torna-se algo eminentemente não natural, isto é, um homem (ARENDT, 2012, p. 602-603).

O fato de que Arendt tenha usado essa noção para se referir à premissa totalitária de modificar a natureza do homem nos campos de concentração não foi suficiente para impedir que sua obra fosse recebida de maneira polêmica por alguns de seus críticos. Talvez por isso, Arendt (2015, p. 12) tenha advertido seus leitores, logo nas primeiras páginas de $A$ Condição Humana, de que "[...] a condição humana não é o mesmo que a natureza humana, e a soma total das atividades e capacidades humanas que correspondem à condição humana não constitui algo equivalente à natureza humana”. Para Arendt (2015, p. 13), a questão da natureza humana é antes uma questão teológica e, por isso, ela somente pode ser resolvida “[...] dentro da estrutura de uma resposta divinamente revelada". Portanto, o problema da natureza humana no pensamento político de Arendt é, com efeito, um falso problema.

Vejamos agora como uma obra singular pode se relacionar de diferentes modos com as regras que tradicionalmente foram estabelecidas para sua composição. A partir da teoria narrativa de Ricoeur (1994), é possível entender em que sentido o filósofo francês buscou ler $A$ Condição Humana como uma antropologia filosófica. Depois de formular sua hipótese de leitura, o próprio Ricoeur se coloca a pergunta se acaso sua interpretação não retornaria a um gênero de meditação já ultrapassado no início da década de 1980. Para Ricoeur (2016, p. 14, tradução nossa):

Não, na medida em que o caráter radicalmente novo do totalitarismo engendrou uma
questão sem precedentes: em quais condições um mundo não concentracionário é
possível? Segundo quais pressupostos os homens deixam de ser supérfluos? A
antropologia filosófica é então concebida de súbito como uma introdução à filosofia
política; mais precisamente, a prova dessa antropologia filosófica seria a própria
política: no sentido de que a anatomia e a fisiologia da condição humana devem

\footnotetext{
${ }^{5}$ Para distinguir os campos de concentração, Arendt propõe uma classificação em três tipos que correspondem às três concepções ocidentais de uma vida após a morte, a saber, o Limbo, o Purgatório e o Inferno. O Limbo é a instituição que torna possível afastar as pessoas indesejadas (refugiados, apátridas, marginais, desempregados etc.) da sociedade; o Purgatório é a instituição representada pelo campo de concentração soviético, onde o abandono e o trabalho forçado eram indissociáveis; e o Inferno é a instituição representada pelo campo de concentração nazista, "[...] onde toda a vida era organizada, completa e sistematicamente, de modo a causar o maior tormento possível" (ARENDT, 2012, p. 591). O que unifica esses três tipos de campo é, segundo Arendt (2012), o fato de que as massas humanas são tratadas como se já estivessem mortas. Em um mundo concentracionário, os seres humanos se tornam supérfluos e, como meros viventes, ninguém se importa se estão vivos ou mortos. "O perigo das fábricas de cadáveres e dos poços de esquecimento é que hoje, com o aumento universal das populações e dos desterrados, grandes massas de pessoas constantemente se tornam supérfluas se continuamos a pensar em nosso mundo em termos utilitários" (ARENDT, 2012, p. 609).
} 
encontrar na reconstrução do espaço político a verificação que a crença de base do sistema totalitário buscou no sistema totalitário.

Se, para Ricoeur, a antropologia filosófica de Arendt foi concebida de um ponto de vista político, e não de um ponto de vista metafísico, é porque esse gênero de meditação é antes um paradigma a partir do qual Arendt pôde inovar, afastando-se das regras sedimentadas por uma tradição ${ }^{6}$. Nesse sentido, poderíamos dizer que a leitura de $A$ Condição Humana como uma antropologia filosófica pressupõe admitir que essa obra não foi configurada como uma aplicação servil das regras que tradicionalmente constitui esse gênero de meditação. Isso significa que se considerarmos a antropologia filosófica como um paradigma, esse gênero de meditação constituiria "[...] somente a gramática que regula a composição de novas obras novas antes de se tornarem típicas" (RICOEUR, 1994, p. 109). É por isto que, na interpretação de Ricoeur, pode-se ler A Condição Humana como uma antropologia filosófica, pois a nova investigação arendtiana se configura como um desvio, um afastamento das regras sedimentadas pela tradição inaugurada por esse gênero de meditação, mantendo assim um diálogo crítico com ela. Em outras palavras, poderíamos afirmar, conforme a interpretação de Ricoeur (1994), que por meio de uma deformação regrada, Arendt teria se afastado desse paradigma, o qual, oriundo de uma inovação anterior, teria lhe fornecido as regras para uma experimentação ulterior. Esse seria o primeiro tipo de afastamento que uma obra singular pode produzir em relação ao seu paradigma (RICOEUR, 1994). Na tradição que envolve as obras literárias, segundo Ricoeur (1994), esses afastamentos ocorrem muito lentamente, de modo que as regras de um paradigma podem resistir às inovações que são produzidas por cada obra singular. "Mas à medida que nos afastamos da narrativa tradicional, o desvio, o afastamento, torna-se a regra" (RICOEUR, 1994, p. 109).

\footnotetext{
${ }^{6}$ É preciso destacar que estamos empregando aqui o conceito de tradição tal como ele é entendido por Paul Ricoeur - e não no sentido arendtiano, isto é, como "[...] o fio que nos guiou com segurança através dos vastos domínios do passado [...]", mas que, em contrapartida, manteve atada "[...] cada sucessiva geração a um aspecto predeterminado do passado" (ARENDT, 2013, p. 130). De acordo com a teoria narrativa de Ricoeur (1996, p. 107), o ato configurante da composição de uma obra contém dois traços que são reativados no ato refigurante da leitura, a saber, o esquematismo e o tradicionalismo. O primeiro traço consiste no conjunto das regras fornecidas pela imaginação produtora que, à maneira da primeira crítica kantiana, esquematiza a tessitura do enredo, de modo que, segundo Ricoeur (1994, p. 107), “[...] se pode falar de um esquematismo de função narrativa”. E o segundo traço consiste na sedimentação dessas regras cuja história teria, para Ricoeur, "[...] todas as características de uma tradição [...]", entendida pelo filósofo francês “[...] não [como] a transmissão inerte de um depósito já morto, mas a transmissão viva de uma inovação sempre suscetível de ser reativada por um retorno aos momentos mais criadores do fazer poético" (RICOEUR, 1994, p. 107). Nesse sentido, é possível entender como uma obra singular pode se afastar das regras sedimentadas por uma tradição, isto é, pode se afastar de um paradigma e inovar - o que vai exigir da imaginação produtora novas regras de composição. De acordo com Ricoeur (1996, p. 109), "A inovação permanece uma conduta governada por regras: o trabalho da imaginação não nasce do nada. Ele liga-se, de um modo ou de outro, aos paradigmas da tradição. Mas pode manter uma relação variável com esses paradigmas".
} 
Nesse sentido, poderíamos dizer então que a antropologia filosófica teria fornecido, à maneira de um paradigma, as regras desse gênero de meditação a partir das quais Arendt teria buscado, por meio de uma deformação regrada, dar uma resposta à questão deixada em aberto por sua análise histórica da estrutura do totalitarismo. Para Ricoeur (1994), esse gênero de meditação teria ainda fornecido para Heidegger, em Ser e Tempo, uma abertura ontológica para o questionamento do modo de ser do ente que nós mesmos somos, isto é, do Dasein. No entanto, para filósofo francês, é preciso ter bastante cuidado ao vincular uma obra singular a um gênero específico de meditação. Ricoeur (1994, p. 109) nos adverte de que uma leitura de $O$ Ser e o Tempo em um sentido puramente antropológico poderia "[...] arruinar o sentido da obra inteira, na medida em que seu desígnio ontológico seria negligenciado”. Segundo Ricoeur (1994, p. 97):

Isolar a antropologia filosófica de $O$ ser e o Tempo é, pois, esquecer essa significação principal de sua categoria existencial central. Permanece que, em O Ser e o Tempo, a questão do ser é precisamente aberta por uma análise que deve, primeiro, ter uma certa consistência no plano de uma antropologia filosófica, para exercer a função de abertura ontológica que lhe é assinalada.

Ainda que o próprio Heidegger $(1989$, p. 83) tenha colocado a questão ontológica do modo de ser do ente fora do escopo de "[...] todas as tendências para uma antropologia filosófica [...]", na interpretação de Ricoeur, a analítica existencial do Dasein teve de buscar nesse gênero de meditação uma certa consistência para que a investigação ontológica do ser-o-aí pudesse ser levada adiante. Assim, poderíamos ler $O$ ser e o tempo como outra modalidade de antropologia filosófica que, segundo Ricoeur (1994, p. 97):

[...] organiza-se com base em uma temática, a da inquietação (Sorge), que sem nunca se esgotar em uma praxeologia, haure, contudo, nas descrições inspiradas na ordem prática a força subversiva que lhe permite abalar o primado do conhecimento pelo objeto e desvelar a estrutura do ser-no-mundo mais fundamental que qualquer relação sujeito-objeto.

Analogamente, poderíamos afirmar que Arendt haure na distinção entre trabalho (work), obra (labor) e ação (action) a força subversiva de sua antropologia filosófica, a qual, ao descrever os traços permanentes de nossa condição humana, permite abalar a hipótese monstruosa do totalitarismo. O que nos interessa aqui é mostrar que, para Ricoeur, mesmo duas obras tão distintas entre si podem se relacionar de modo distinto com um mesmo paradigma. Portanto, a questão não se refere à pertinência de classificar uma obra segundo as regras de um determinado gênero de meditação, mas ao modo como cada obra singular se relaciona com as regras de composição que se sedimentaram ao longo de uma tradição de pensamento filosófico. 
Para os nossos propósitos, é importante observar, conforme a teoria narrativa de Ricoeur (1994), que o ato da leitura é a mediação entre o mundo configurado pela obra e o mundo refigurado pelo leitor. Para Ricoeur (1994), a leitura é uma atividade estruturante que permite ao leitor não apenas completar o sentido sempre aberto e inacabado de uma obra, mas também refigurar o mundo que ela projeta. Através da leitura, o leitor se situa no horizonte aberto pela obra, e, situado no mundo do texto, ele é capaz de expandir o horizonte de seu próprio mundo 7 . Nesse sentido, o ato de ler é o ponto no qual o leitor pode compreender tanto o texto quanto a si mesmo. Assim, a leitura permite ao leitor tomar distância de si mesmo e se situar como outro no horizonte aberto pelo mundo da obra. Poderíamos dizer que o leitor da obra arendtiana, ao se situar no horizonte aberto pela análise da condição humana, é convidado - talvez, em nossos dias, ousaríamos dizer que somos convocados - a pensar sob quais condições é possível edificar um mundo não totalitário; pensar sob quais condições é possível abrir, preservar ou reconstruir um espaço político (RICOEUR, 2016).

Essa abertura, preservação ou reconstrução de um espaço político, de um espaço entre os seres humanos no qual seja possível aparecer uns aos outros mediante atos e palavras, como vimos, depende da capacidade humana de iniciar algo novo, isto é, de agir. Para Étienne Tassin (1991), a preservação de um espaço político na medida em que propicia a aparição e a visibilidade é a condição de possibilidade para existência de um mundo de coisas que possuímos em comum. Ainda que, para Arendt (2015), essa capacidade de iniciar algo novo seja inerente à novidade que vem ao mundo a cada nascimento, um recém chegado só a possui em potência. Ou seja, para um ser novo que acaba de chegar no mundo e que, portanto, não se encontra acabado, mas em estado de vir a ser (state of becoming), a capacidade de agir é uma presença privativa (AGAMBEN, 2017). Somente quando um ser humano pode agir e não agir, pode iniciar ou não iniciar algo novo no mundo, que ele se torna um ser potente, isto é, um ser capaz de agir, um ser cuja capacidade de agir pode passar da potência ao ato. A partir do pensamento de Arendt (2013), pode-se afirmar que, para um recém chegado que está em processo de vir a ser (process of becoming), a capacidade de agir é a presença de algo que se encontra igualmente em processo de vir a ser.

\footnotetext{
${ }^{7}$ É importante, mais uma vez, deixar claro que, para Ricoeur, o conceito de mundo ou, mais precisamente, o de mundo do leitor aponta não para as coisas que existem entre nós e conferem estabilidade à morada humana na Terra (ARENDT, 2015), mas para o conjunto de referências que se abre através da leitura. "O termo 'mundo' tem, pois, o significado que todos entendemos ao dizermos de um recém nascido que veio ao mundo. Para mim, o mundo é o conjunto de referências desvendadas por todo tipo de texto, descritivo ou poético, que li, compreendi e amei” (RICOEUR, 1976, p. 49).
} 
É por isso que, para Arendt, não se deve confundir o ato educativo com a ação política. Ainda que seja inerente à tarefa educativa e, sobretudo, ao ofício de professor, uma dimensão política, é preciso distinguir essa atividade por meio da qual apresentamos o mundo aos recém chegados daquela atividade que, mediante atos e palavras, podemos romper com o curso automático das coisas (CARVALHO, 2017). "A educação não pode desempenhar nenhum papel na política, pois na política lidamos sempre com aqueles que já estão educados" (ARENDT, 2013, p. 225). Pode-se dizer, em outras palavras, que na política lidamos sempre com aqueles que já completaram o processo de vir a ser e, portanto, são capazes de agir e não agir, isto é, podem iniciar e não iniciar algo novo no mundo. Além disso, para Arendt (2015), a ação - e não educação! - é uma espécie de segundo nascimento. Se, pelo nascimento, somos inseridos no mundo, é somente com atos e palavras que nos inserimos por nossa própria inciativa no mundo. Conforme Arendt (2015, p. 219), essa inserção em um espaço de aparência e visibilidade é "[...] como um segundo nascimento, no qual confirmamos e assumimos o fato simples de nosso aparecimento físico e original". Se, na política, lidamos sempre com aqueles que já estão educados; na educação, lidamos sempre com aqueles que ainda não desempenham nenhum papel na política.

À luz dessas considerações, poderíamos afirmar que a educação é uma abertura por meio qual os recém chegados podem participar do espetáculo do mundo não como atores, mas como espectadores. É dessa posição que esses seres em processo de vir a ser podem se apropriar de um mundo de coisas interposto entre nós, e, medida em que tornam próprio o que lhes era estranho, os recém chegados vão se aproximando à distância do espetáculo do mundo. Nesse sentido, é somente como espectadores ou como leitores, conforme a teoria narrativa de Ricoeur (1994), que os recém chegados podem se situar no horizonte aberto pelas obras e pelos monumentos do passado que constituem nosso mundo comum. Assim, a educação pode ser vista como a atividade que permite aos recém chegados estabelecer uma relação imparcial e desinteressada com o mundo. De acordo com Odílio Alves Aguiar (2002, p. 95):

Sem a postura do espectador, a visada interrogativa ao mundo não se apresenta. O
sentido ficaria para sempre oculto se não surgisse alguém apaixonado para manifestá-
lo. O espectador nem visa a um distanciamento completo do mundo para depois
adequá-lo à contemplação, nem a substituir o processo de deliberação inerente à esfera
pública. Essa abertura para o sentido impõe, por ela mesma, como condição para sua
tematização, uma retirada (withdrawal) do agir e um desinteresse em relação a uma
finalidade intencional, seja um valor ou interesse. Essas condições são resumidas por
Arendt na palavra imparcialidade.

Para os nossos propósitos, é notável a importância para a educação dessa postura do espectador; dessa atitude de quem observa, examina e julga as coisas que são colocadas entre 
nós como algo que possuímos em comum. Essa postura do espectador propicia aos recém chegados uma visada interrogativa, nas palavras de Odílio Aguiar; permite o exercício de um olhar atento para com o espetáculo do mundo. É somente para um espectador (spectator) que o mundo pode se tornar um espetáculo (spectaculum) e as coisas mundanas podem se tornar dignas de um olhar atento (spectare). Portanto, para seres em processo de vir a ser, a atividade da educação é uma abertura para o sentido das coisas materiais e simbólicas do mundo, uma possibilidade de apropriar-se à distância do mundo de coisas interposto entre nós.

\subsection{A atividade da educação e a condição temporal de seres mortais}

Vimos, conforme a teoria narrativa de Ricoeur (1994), de que maneira uma obra singular pode se relacionar de modo distinto com as regras de composição fornecidas por um mesmo paradigma. Desse modo, é possível entender como A Condição Humana pode ser lida como uma modalidade de antropologia filosófica. Em outras palavras, com essa teoria podemos entender de que maneira uma obra singular pode inovar as regras sedimentadas por uma tradição. Contudo, essa teoria não nos dá nenhuma pista de como a educação estaria vinculada, no projeto filosófico arendtiano, à sua tentativa de compreender a essência do totalitarismo, nem de como essa atividade estaria relacionada à sua nova investigação que buscou responder sob quais condições é possível erigir um mundo não totalitário. Com base na interpretação de Ricoeur (2016), buscaremos explicitar o vínculo entre a atividade da educação e o modo como Arendt buscou responder, em $A$ Condição Humana, a questão deixada em aberto em sua primeira grande obra. Se Arendt buscou descrever as capacidades humanas, de acordo com a leitura de Ricoeur (2016), como estruturas históricas que conservam, ao longo de suas múltiplas mutações, os traços perduráveis da condição humana, seria possível identificar na atividade da educação, ao longo de suas diversas transformações, algum tipo de identidade flexível, algum traço perdurável que não pode ser perdido enquanto não mudar a própria condição humana?

Tentaremos, nas próximas páginas deste capítulo, dar uma resposta a essa questão. Conforme a interpretação de Ricoeur (2016), uma das linhas fundamentais da nova investigação levada a cabo por Arendt em $A$ Condição Humana consistia em responder sob quais condições é possível erigir um mundo não concentracionário. Para tanto, a análise arendtiana buscou identificar os traços que são permanentes naquelas atividades em que os seres humanos se encontram engajados no mundo. Para Arendt (2015), a distinção entre vita activa e vita contemplativa é fundamental para entender as mudanças ocorridas ao longo do tempo na 
hierarquia das atividades humanas. Desse modo, a fim de escrutinar, por um lado, como a descoberta da contemplação turvou as diferenças e as articulações entre as atividades que ocorrem no campo prático da existência humana e, de outro, como esse turvamento se manteve inalterado mesmo depois da ruptura com a tradição e da inversão da ordem hierárquica tradicional, promovidas, sobretudo, pelo pensamento de Nietzsche e de Marx, Arendt teria pressuposto, conforme a interpretação de Ricoeur (2016, p. 17, tradução nossa), “[...] um valor normativo regulado por alguma constituição teleológica durável”. Na leitura de Ricoeur (2016, p. 17, destaque do autor, tradução nossa), esse arranjo normativo e teleológico ("mise em ordre normative et téléologique”) se justificaria de maneira convincente se as categorias contidas na distinção entre trabalho, obra e ação fossem consideradas como "[...] respostas específicas a questões específicas colocadas pela condição temporal de seres mortais”. Partindo dessa interpretação, pode-se afirmar que, no projeto filosófico de Arendt, a atividade da educação pode ser igualmente considerada como uma resposta específica a uma questão específica colocada por nossa condição temporal de seres mortais. E, no âmbito da educação, poderíamos traduzir essa questão específica da seguinte maneira: Como um ser humano novo e em processo de vir a ser se torna uma pessoa? Como um recém chegado no mundo se constitui como um alguém?

Esse processo de constituir-se como um alguém tem início com a nossa chegada no mundo, com o nosso aparecimento físico original. Ele está vinculado ao fato do nascimento, ou seja, ao fato de que a cada nascimento vem ao mundo um ser único e singularmente novo que, na medida em que se familiariza com os objetos da cultura, vai paulatinamente elaborando sua identidade pessoal; vai se identificando com personagens e enredos que passam a constituir sua própria estória de vida. Desse modo, poderíamos dizer que esse processo de constituição de um alguém se realiza quando nos tornamos capazes de responder a esse fato; quando podemos começar ou não começar algo novo no mundo; quando por nossa própria iniciativa podemos aparecer ou não aparecer junto aos outros (AGAMBEN, 2017). Em outras palavras, pode-se afirmar que o término do processo educativo ocorre quando os mais novos se tornam capazes de, por iniciativa própria, aparecer junto aos outros mediante atos e palavras. Constituir-se como um alguém é, para os mais novos, um pôr-se a caminho do quem se quer ser, um caminho no qual nenhum recém chegado no mundo pode deixar de percorrer na qualidade de ser único, isto é, de pessoa. "Desse alguém que é único pode-se dizer verdadeiramente que antes dele não havia ninguém" (ARENDT, 2015, p. 220).

Em uma passagem de seu Diário Filosófico, escrito em 1969, Arendt (2005, p. 757, tradução nossa) descreve o início desse processo e aponta para o movimento de sua realização: 
Quando nascemos no mundo, primeiro nos vemos confrontados exclusivamente com o que aparece, com o perceptível sensivelmente. Visto que nascemos nele como estranhos, como estrangeiros se somos vistos a partir do mundo, nos sentimos de repente tomados pela admiração e nossas perguntas se colocam no sentido de nos familiarizarmos com o mundo.

Poderíamos dizer que, para os recém chegados, a atividade da educação consiste no exercício dessa capacidade de admirar-se e de fazer perguntas no sentido de familiarizar-se com o mundo. É desse modo que a educação pode propiciar aos mais novos uma abertura para o sentido, o qual permaneceria escondido se não fosse a presença de um ser humano novo que, tomado pela admiração, volta-se para as coisas do mundo - e para si mesmo - com uma visada interrogativa (AGUIAR, 2002).

Nesse sentido, esse processo de familiarizar-se com o mundo pode ser entendido como o processo no qual os mais novos se apropriam à distância das coisas que possuímos em comum. Em outras palavras, para os educandos, a atividade da educação consiste em tornar próprio o que antes era percebido como estranho. É nesse confronto com as coisas do mundo, nesse contato com as obras e os monumentos do passado, que um ser novo vai elaborando sua identidade pessoal. Assim, se somos inseridos no mundo humano como estranhos e vistos como estrangeiros a partir do mundo, pode-se afirmar, conforme Arendt (2005), que a atividade da educação propicia aos mais novos um tempo oportuno para formular uma resposta à pergunta que se faz a todo recém chegado: quem és? (ARENDT, 2015). Esse estranho que acaba de nascer, esse estrangeiro que acaba de chegar no mundo é, para Arendt ([1961] 2013, tradução nossa), o sujeito da educação ${ }^{8}$ (subject of education). Ele aparece para o educador sob um duplo aspecto, isto é, como um ser humano novo (new human being) e um ser humano em vir a ser (becoming human being). Nesse sentido, enquanto um recém chegado se familiariza com o mundo, enquanto o sujeito da educação se encontra em processo de vir a ser, pode-se dizer que ele ainda não é capaz de aparecer por inciativa própria, de estar junto aos outros no espaço público e, mediante atos e palavras, revelar sua distinção única (ARENDT, 2015). Para Arendt $(2015,2013)$, a revelação do quem requer uma exposição à luz do domínio público contra a qual a vida dos mais novos deve ser protegida. É por isso que, conforme Arendt (2013), ao assumirmos a responsabilidade de educar os mais novos, deve-se assumir a dupla

\footnotetext{
${ }^{8} \mathrm{Na}$ edição brasileira, o sintagma "subject of education" foi traduzido por "objeto da educação". Para Arendt (2000, p. 17), "A mundanidade das coisas vivas significa que não há sujeito que não seja também objeto e que não apareça como tal para alguém que garanta sua realidade 'objetiva". Ainda que, nesse sentido, o sujeito da educação seja também o objeto da educação, preferimos verter o sintagma "subject of education" por "sujeito da educação".
} 
responsabilidade pela vida e pelo desenvolvimento da criança, por um lado, e pela continuidade do mundo, por outro 9 .

Nesse processo de familiarizar-se com o mundo, o sujeito da educação aparece não apenas como um ser único e distinto por seu corpo e suas qualidades físicas, mas também se torna capaz de distinguir a si mesmo através da palavra. Ou seja, na medida em que se familiariza com o mundo, o sujeito da educação se apropria da linguagem e se torna capaz de exprimir sua distinção única. Evidentemente, essa apropriação não significa ter a propriedade nem a posse de algo. Como observa José Sérgio de Carvalho (2017), há objetos simbólicos que, embora sejam concebidos correntemente como bens públicos, não são propriedade nem pública nem privada.

\begin{abstract}
A língua portuguesa - como o tupi - não é uma propriedade ou posse, em sentido estrito, de ninguém, embora seja visto como um bem simbólico comum e público. Tampouco seu caráter público deriva de qualquer sorte de vínculo ou controle estatal, mas do fato de ser um objeto da cultura comum de um povo (CARVALHO, 2017, $\mathrm{p}$. 12 , itálico nosso).
\end{abstract}

Pode-se afirmar, nesse sentido, que o processo de se familiarizar com o mundo implica em apropriar-se de objetos culturais que não são propriedade nem posse de ninguém. Desse modo, pode-se dizer que a tarefa da educação consiste em apresentar aos mais novos os objetos da cultura que julgamos dignos de permanecer no mundo. Na qualidade de sujeitos da educação, os mais novos precisam se apropriar desses objetos. Para que possam se inserir no mundo e distinguir a si mesmos, precisam falar sobre esses objetos a partir de um lugar próprio. É, portanto, no domínio simbólico da linguagem, que um ser novo no mundo pode distinguir a si mesmo e, referindo-se aos objetos da cultura ou às coisas que existem objetivamente entre nós, pode tomar a palavra e dizer algo em nome próprio.

Desse modo, é somente quando um ser novo se insere através da palavra no mundo humano que ele se torna capaz de distinguir a si mesmo. Ou seja, ao endereçar a palavra a uma outra pessoa, um recém chegado não apenas é visto como um ser distinto, mas exprime por iniciativa própria sua distinção única. Para Arendt (2015), essa inserção no mundo humano não é imposta pela necessidade da vida nem é desencadeada pela utilidade das coisas. O impulso

\footnotetext{
9 É importante observar que, nessa passagem de A crise na educação, Arendt (2013) se refere à dupla responsabilidade dos pais humanos que não apenas trouxeram seus filhos à vida através da concepção e do nascimento, mas também os introduziram em um mundo. A atividade da educação repousa, portanto, em uma dupla relação com a vida do recém chegado e com o mundo no qual foi inserido pelo nascimento. "Essas duas responsabilidades de modo algum coincidem; com efeito podem entrar em mútuo conflito. A responsabilidade pelo desenvolvimento da criança volta-se em certo sentido contra o mundo: a criança requer cuidado e proteção especiais para que nada de destrutivo lhe aconteça de parte do mundo. Porém também o mundo necessita de proteção, para que não seja derrubado e destruído pelo assédio do novo que irrompe sobre ele a cada nova geração" (ARENDT, 2013, p. 235).
} 
que move os seres humanos para esse espaço de aparência no qual podem revelar quem eles são surge do início que vem ao mundo a cada nascimento; da iniciativa que ninguém pode se abster sem deixar de ser humano (ARENDT, 2015). É, portanto, graças a nossa capacidade de iniciar algo novo no mundo, isto é, de agir, que somos reconhecidos por nossa unicidade (uniqueness), e não apenas em razão de nossa alteridade (otherness), que compartilhamos com tudo o que existe, ou de nossa distinção (distinction), que compartilhamos com tudo o que é vivo (ARENDT, [1998] 2015). Para Arendt, somente nós, seres humanos, podemos nos tornar seres singularmente distintos porque somos os únicos seres capazes de exprimir nossa distinção através da palavra, isto é, podemos comunicar aos outros não apenas nossas necessidades vitais, mas também exprimir o que se passa conosco diante das coisas do mundo no qual fomos inseridos pelo nascimento e nos inserimos por iniciativa própria na modalidade da ação e do discurso.

Para os nossos propósitos, é importante destacar que, para Arendt, esse ser novo que se encontra em processo de vir a ser, o sujeito da educação, volta sua visada interrogativa ao mundo no sentido de familiarizar-se com ele. Se, na qualidade de seres humanos novos e em processo de vir a ser, somos vistos na perspectiva do mundo como estrangeiros, poderíamos dizer que a educação consiste em criar laços de pertencimento com as coisas materiais e simbólicas que possuímos em comum. Familiarizar-se com o mundo significa fazer sociedade com ele, compartilhar as coisas mundanas que não são propriedades de ninguém e que, por isso, estabelecem laços simbólicos com os que vieram antes de nossa chegada e com os que virão depois de nossa partida. Para fazer sociedade com as obras e os monumentos do passado, é preciso demorar-se juntamente a esses objetos da cultura, sair em visita dessas coisas que podem permanecer no mundo através de gerações e frequentá-la como se estivéssemos em casa. A atividade da educação é, nesse sentido, uma abertura para que os mais novos possam se associar, através das coisas que possuímos em comum, com homens e mulheres do passado, que com suas obras e estórias de vida nos legaram uma herança sem testamento, parafraseando os versos de René Char, citados por Arendt no prefácio de Entre o passado e o futuro. É nesse sentido, segundo Alain (1978), que os mais novos ao lerem os poemas de Homero fazem sociedade não apenas com o poeta, mas também com os personagens e todas aquelas pessoas que apenas ouviram o nome do poeta.

Quando leio Homero, faço sociedade com o poeta, sociedade com Ulisses e com Aquiles, sociedade também com a multidão daqueles que leram estes poemas, e ainda com a multidão daqueles que apenas ouviram o nome do poeta. Em todos eles, e em mim, faço soar o humano, ouço os passos do homem (ALAIN, 1978, p. 172). 
Se, como vimos acima, um recém chegado ainda não é capaz de responder à pergunta sobre quem ele é, poderíamos dizer que o sujeito da educação se põe a caminho da pergunta sobre quem ele quer ser. É a partir desse querer que os mais novos se movem entre as coisas com as quais se relacionam a fim de que o mundo se torne menos estranho ou mais familiar para eles. Para Arendt (2000), o querer, a faculdade da vontade, é o nosso órgão espiritual voltado para o futuro, assim como o lembrar, a faculdade da memória, é o nosso órgão espiritual voltado para o passado. Ao se familiarizar com o mundo, ao fazer sociedade com ele, o sujeito da educação não apenas lida com objetos, mas também com projetos (ARENDT, 2000). Assim, na medida em que eu volitivo do sujeito da educação se enlaça com o mundo, ou seja, na medida em que, ao se familiarizar com o mundo, um ser novo identifica e acolhe seu desejo de ser, seu esforço de existir se volta para quem ele quer ser. Nesse sentido, poderíamos dizer, seguindo as análises de Paul Ricoeur (1983, p. 376, tradução nossa), que a identidade pessoal do sujeito da educação depende das narrativas que ele constrói de si mesmo diante das obras e dos monumentos do passado. A elaboração de nossa identidade pessoal, segundo Ricoeur (2013, p. 383, itálico do autor, tradução nossa), depende de nossas “[...] identificações com... heróis, personagens emblemáticas, modelos e mestres, e também com princípios, normas que vão dos costumes tradicionais até os paradigmas utópicos que, emanando do imaginário social, remodelam nosso imaginário privado [...]". Nesse sentido, afastando-se dele próprio e se aproximando das coisas materiais e simbólicas do mundo, o sujeito da educação constrói sua identidade pessoal. Poderíamos dizer, a partir da teoria narrativa de Ricoeur, que o sujeito da educação, na medida em que elabora sua identidade pessoal, pode ser visto como um leitor de si mesmo diante do mundo. Ao se perder por entre os objetos da cultura e refigurar o horizonte de seu imaginário privado a partir das obras e monumentos do passado, o sujeito da educação encontra a si mesmo como uma pessoa única e igualmente distinta de todas as outras ${ }^{10}$.

Nesse ponto, reencontramos a interpretação de Ricoeur (2016) a partir do próprio âmbito da educação. Se, para Ricoeur (2016, p. 27), “[...] a política [no pensamento de Arendt]

\footnotetext{
${ }^{10}$ Para Ricoeur (1986), a leitura é a mediação que permite ao leitor reconfigurar o mundo configurado pelo autor, o mundo do texto, situando-se no horizonte aberto pela obra. $\mathrm{O}$ ato de ler possibilita, nesse sentido, uma abertura na realidade cotidiana através da qual, por meio de variações imaginativas, o leitor pode reconfigurar sua maneira de habitar o mundo. Em outras palavras, pode-se dizer que o mundo do leitor é configurado pela interpretação de uma proposição de mundo; de um mundo no qual ele possa se situar e projetar novas possibilidades de compartilhar o mundo com os outros (RICOEUR, 1986; ARENDT, 2015). Desse modo, o sujeito da educação pode ser visto como um leitor de si mesmo na medida em que, ao familiarizar-se com os objetos da cultura, novas possibilidades de habitar o mundo são abertas; novos modos de compartilhar o mundo com os outros são abertos ao longo do processo educativo. "Leitor, eu não me encontro senão perdendo-me. A leitura me introduz na variação imaginativa do ego. A metamorfose do mundo, conforme o jogo, é também a metamorfose lúdica do ego" (RICOEUR, 1986, p. 115, tradução nossa).
} 
marca o esforço supremo do ser humano para se 'imortalizar' a si mesmo [...]”, pode-se afirmar que a educação marca o esforço supremo do recém chegado para se constituir como um alguém. Para os mais velhos, para aqueles que assumem a responsabilidade de apresentar o mundo para os recém chegados, a educação marca o esforço supremo para abrigar e proteger um mundo de coisas que, não fosse a chegada de seres novos, estaria condenado a desaparecer com o passar do tempo. Como uma resposta específica a uma pergunta específica colocada por nossa condição temporal de seres mortais, a educação é a atividade através da qual manifestamos, ao mesmo tempo, nosso amor mundi, nosso amor pelo mundo de coisas materiais e simbólicas interposto entre nós, e nosso amor pelos mais novos cuja tarefa consiste em renovar o mundo comum. Por isso, conforme Arendt (2013), a educação precisa ser conservadora, precisa conservar as obras e os monumentos do passado a fim de que os mais novos possam preservar o mundo contra a mortalidade de seus criadores e habitantes. Segundo Arendt (2013, p. 247):

A educação é o ponto em que decidimos se amamos o mundo o bastante para
assumirmos a responsabilidade por ele e, com tal gesto, salvá-lo da ruína que seria
inevitável não fosse a renovação e a vinda dos novos e dos jovens. A educação é,
também, onde decidimos se amamos nossas crianças o bastante para não expulsá-las
de nosso mundo e abandoná-las a seus próprios recursos, e tampouco arrancar de suas
mãos a oportunidade de empreender alguma coisa nova e imprevista para nós,
preparando-as em vez disso com antecedência para a tarefa de renovar o mundo
comum.

Assim, na medida em que os mais novos buscam, por um lado, familiarizar-se com o mundo, sair em visita e fazer sociedade com as obras e os monumentos do passado, é preciso que os mais velhos manifestem seu amor para com as coisas do mundo. Na qualidade de educadores, temos a dupla responsabilidade de proteger e abrigar tanto os objetos da cultura que julgamos dignos de permanecer entre nós quanto a novidade que vem ao mundo a cada nascimento. Pelo pensamento arendtiano, a tarefa de educar os mais novos nos coloca a questão de como é possível preservar o mundo contra a mortalidade de seus habitantes que nascem continuamente; de como é possível acolher o constante influxo de seres mortais tendo em vista a potencial imortalidade do mundo comum. É nesse sentido que tanto as atividades do trabalho, da fabricação e da ação, conforme a análise arendtiana em A Condição Humana, quanto a atividade da educação, podem ser lidas como respostas específicas a questões específicas colocadas por nossa condição temporal de seres mortais. Poderíamos afirmar, nesse sentido, que a tarefa fundamental da educação não é a de produzir conhecimentos nem a de desenvolver habilidades e competências, mas antes consiste em apresentar aos mais novos as obras e os monumentos do passado que julgamos dignos de permanecer ao longo de gerações e, ao mesmo tempo, em preservar a novidade que vem ao mundo a cada nascimento a fim de introduzi-la 
como algo novo em um mundo velho que está sempre rente à destruição (ARENDT, 2013). Uma antropologia filosófica para educação nos abre, portanto, a possibilidade de (re)pensar nossa relação com o mundo e com os mais novos, com a permanência das coisas que conferem estabilidade à morada de seres mortais na Terra e com um mundo novo que, potencialmente, passa a existir com a chegada de novos seres humanos. 


\title{
3. A FRAGILIDADE DA EDUCAÇÃO NA CONSTITUIÇÃO DE UM $A L G U E ́ M$
}

\begin{abstract}
Ao agir e ao falar, os homens mostram quem são, revelam ativamente suas identidades pessoais únicas, e assim fazem seu aparecimento no mundo humano, enquanto suas identidades físicas aparecem, sem qualquer atividade própria, na conformação singular do corpo e no som singular da voz.
\end{abstract}

Hannah Arendt, A Condição Humana.

Em História da Educação na Antiguidade, o historiador francês, Henri-Irénée Marrou (1973), mostra como o exemplo heroico $(\pi \alpha \rho \alpha ́ \delta \varepsilon \imath \gamma \mu \alpha)$ na obra de Homero forjou não apenas o modelo para a educação dos mais novos no mundo antigo, mas também a base fundamental para toda tradição pedagógica clássica. Segundo Marrou (1973), a permanência da obra homérica no âmbito da educação se deve ao fato de que ela fornecia mais do que um inventário de saberes e práticas - de habilidades e competências, diríamos hoje - nos quais os jovens helenos deveriam ser iniciados. Para o autor, esse era apenas um dos aspectos que toda educação digna desse nome deveria apresentar. É com base nos exemplos heroicos de Aquiles, na Ilíada, e de Ulisses, na Odisseia, que a educação homérica se apresentava, ao mesmo tempo, como uma técnica, por meio da qual os mais novos eram iniciados e preparados para demonstrar sua

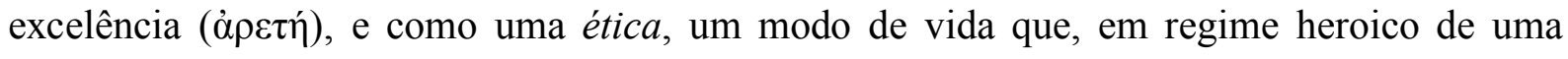
sociedade de guerreiros, estava voltado para a honra e o amor à glória (MARROU, 1973).

Com base nas análises de Montesquieu (1996), em O Espírito das Leis, poderíamos dizer que, no mundo configurado pela obra homérica, a honra e o amor à glória eram virtudes políticas que moviam a aristocracia guerreira. Em outras palavras, pode-se dizer que a honra e o amor à gloria eram princípios que moviam aquela sociedade de guerreiros e seu modo de vida correspondente, princípios que orientavam as ações e os discursos dos heróis no mundo configurado por Homero. Nesse sentido, a permanência da obra homérica no âmbito da educação repousa no fato de que eram as mesmas paixões humanas que animavam tanto o modo de vida daquela "[...] sociedade de atletas e de combatentes [...]", nas palavras de Montesquieu (1996, p. 61), quanto a educação dos mais novos. Por isso, na filosofia política de Montesquieu (1996), a atividade da educação deve assumir um papel distinto e igualmente fundamental na estrutura de cada uma das formas de governo. Pois, na medida em que seu principal objetivo era o de preparar os futuros cidadãos de uma determinada forma de governo, a educação jamais deveria se limitar à transmissão de conhecimentos - ao seu aspecto técnico, nas palavras de Marrou (1973). "Normalmente, temos o poder de transmitir nossos conhecimentos a nossos 
filhos; temos o poder ainda maior de transmitir-lhes nossas paixões" (MONTESQUIEU, 1996, p. 46). Para que o objetivo da educação pudesse ser alcançado, conforme Montesquieu, era preciso transmitir também aos mais novos as paixões que colocam em movimento os princípios que animam cada uma das formas de governo, de modo a orientar as ações dos futuros cidadãos.

O que nos interessa aqui é tão somente destacar, conforme o pensamento de Montesquieu (1996), que, a fim de atingir seus objetivos, a atividade da educação não deve se reduzir à transmissão de conhecimentos. E mesmo que o principal objetivo da educação estivesse voltado para a preparação de futuros cidadãos, ou seja, mesmo que fosse concebida como um instrumento político instituído legalmente por uma determinada forma de governo, ela jamais deveria se limitar ao seu aspecto técnico. Assim, a transmissão dessas paixões que animam e orientam as ações humanas deve estar na base de toda educação digna desse nome. No caso da educação homérica, a honra e o amor à glória podem ser lidos, através do pensamento de Montesquieu (1996), como o motor daquela sociedade de guerreiros; o motor que colocava em movimento as ações e os discursos daqueles que buscavam ser sempre os

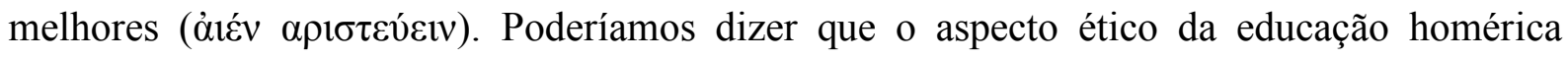
consistia em familiarizar os mais novos com essas paixões humanas, com esses princípios de ação que orientavam os heróis no mundo configurado por Homero.

$\mathrm{Na}$ interpretação de Hannah Arendt (2013b), a grande contribuição do pensamento de Montesquieu consiste na revisão dos pilares conceituais que definem o poder como relação entre governantes e governados e a lei como limitação desse poder. Para Arendt (2013b), a distinção de Montesquieu entre a natureza ou a estrutura particular de uma forma de governo e seu princípio correspondente que a põe em movimento é totalmente nova na tradição de filosofia política. Essa distinção provoca um deslocamento no modo de pensar o funcionamento das formas de governo tradicionais, a saber, democracia, monarquia, aristocracia e tirania, que eram definidas com base no número de pessoas que podiam exercer o poder. A novidade dessa distinção que articula a estrutura particular de uma forma de governo a um princípio correspondente que a move consiste, segundo Arendt (2013b), em considerar as paixões como princípios da ação humana. Desse modo, para Arendt (2013, 2013b), a honra, a glória, o amor à igualdade e seus contrários são princípios de ação que orientam o modo como os seres humanos aparecem por iniciativa própria no espaço público e político.

Para os nossos propósitos, é importante observar que, para Arendt (2103b), esses princípios de ação não devem ser confundidos com motivações psicológicas que operam subjetivamente nos recônditos da alma ou no interior do eu. Para Arendt (2013), esses princípios que inspiram a ação só se manifestam plenamente no ato de sua realização, isto é, 
somente se manifestam no mundo enquanto dura a ação. É por isso que, conforme a interpretação de Arendt (2013), o princípio inspirador da ação pode conservar seu vigor e sua validade ao longo de gerações, de modo que ele pode se repetir inúmeras vezes sem sofrer nenhuma alteração ou desgaste. Pois, na medida em que o princípio da ação jamais se encerra em uma pessoa ou um grupo, ele pode ser universalmente válido. À luz dessas considerações, poderíamos nos perguntar se a permanência da obra homérica no âmbito da educação pode ser interpretada como uma espécie de transposição dos princípios de ação que animavam aquela sociedade de guerreiros para a esfera pré-política da vida humana. Se observarmos que o aspecto ético da educação homérica se revelava plenamente por meio do exemplo heroico de Aquiles e de Ulisses, poderíamos afirmar que os princípios que inspiravam a ação dos heróis no mundo homérico eram os mesmo que, no âmbito da educação, moviam o desejo dos mais novos de ser sempre o melhor.

Ainda que, em nossos dias, o aspecto ético tenha sido quase completamente ocultado pelo aspecto técnico da educação, não se pode negligenciar a presença de tais princípios que movem o desejo de ser daqueles que acabaram de chegar no mundo. Poderíamos dizer que eles constituem o ponto de partida para que os recém chegados possam responder à pergunta: quem és? Ocorre que, para Arendt (2015), essa pergunta somente pode ser respondida por aqueles que já estão educados, pois o quem só se revela quando nos inserimos por iniciativa própria no mundo humano e aparecemos mediante atos e palavras, isto é, quando podemos começar ou não algo novo no mundo. Essa pergunta que se faz a todo recém chegado só pode ser respondida quando o mundo no qual fomos inseridos pelo nascimento se torna familiar o suficiente para nos inserirmos nele por iniciativa própria; quando o mundo de coisas interposto entre nós deixa de ser visto como algo estranho e deixamos de ser vistos, do ponto de vista do mundo, como estrangeiros. E se, para Arendt (2015), a revelação do quem depende de nossa capacidade de aparecer por iniciativa própria em um espaço no qual interagimos com os outros, que papel a educação pode desempenhar no processo de elaborar essa identidade pessoal que se relava mediante atos e palavras? Em outras palavras, em que medida a educação pode contribuir para a constituição de um alguém que se encontra em processo de vir a ser?

Antes de tudo, é preciso lembrar que, para Arendt (2013), não se deve confundir ato educativo com ação política. Iniciar algo novo no mundo é completamente diferente de apresentar aos mais novos o mundo. E ainda que seja inerente aos modos de apresentar o mundo uma dimensão política, para Arendt (2013), é preciso distinguir claramente a fronteira que separa a educação da política (CARVALHO, 2017). Não obstante, como vimos acima, no exemplo da educação homérica, os princípios que moviam aquela sociedade de guerreiros eram 
os mesmos que inspiravam a ação dos heróis no mundo configurado por Homero e moviam o desejo dos mais novos de ser sempre os melhores. Portanto, embora essas duas atividades devam ser separadas a fim de que cada uma mantenha sua dignidade própria, elas estão vinculadas por princípios que são comuns tanto ao âmbito político quanto ao âmbito prépolítico da existência humana. Se, conforme Arendt (2013), esses princípios que inspiram a ação somente se manifestam em ato, isto é, por um agente que se revela mediante atos e palavras, de que maneira esses princípios podem se manifestar em ato no âmbito da educação? Ou seja, se, para Arendt (2013), a educação não pode desempenhar nenhum papel na política porque, no âmbito político, lidamos sempre com aqueles que já estão educados, com aqueles que já são capazes de por iniciativa própria começar algo novo no mundo, como é possível que esses princípios possam inspirar aqueles que ainda se encontram em processo de vir a ser e, portanto, ainda não são capazes de agir politicamente e revelar quem eles são?

Tentaremos, ao longo desse capítulo, dar uma resposta à essas perguntas. Primeiro, mostraremos, à luz da interpretação de Paul Ricoeur (2013), de que maneira a educação está relacionada com a desproporção íntima de seres que sabem que são mortais e que pensam o que é eterno. Em seguida, buscaremos descrever as diferenças e articulações entre a educação e aquelas capacidades gerais que provém de nossa condição humana, a saber, o trabalho (labor), a obra (work) e a ação (action). E, por fim, veremos que a fragilidade da educação no processo de constituir-se como um alguém é, ao mesmo tempo, a sua grandeza.

\subsection{A desproporção íntima de seres temporais que pensam o que está fora do tempo}

De acordo com a interpretação de Ricoeur (2016), ao considerar a distinção entre as categorias da vita activa, Arendt o teria feito com base em nossa condição temporal de seres mortais. É nesse sentido, conforme Ricoeur (2016), que a questão do tempo está colocada na investigação arendtiana sobre o trabalho, a obra e a ação; ou, mais precisamente, é desse modo que o tempo é colocado como questão em sua análise das capacidades gerais que provém de nossa condição humana. Se, para Arendt (2015), a condição humana da natalidade (e não a da mortalidade!) é a categoria central de seu pensamento político, ao sublinhar a análise da vita activa como resposta às questões colocadas pela condição de seres mortais, Ricoeur não teria negligenciado o cerne do pensamento arendtiano? Não, se entendemos nossa condição temporal de seres mortais não apenas como a marca indelével de nossa finitude, mas também de nossa capacidade temporalmente finita de iniciar algo novo no mundo. Para Arendt (2015), se não fosse nossa faculdade de interromper o curso automático da vida cotidiana e começar algo novo, 
o mundo no qual fomos inseridos pelo nascimento estaria condenado à destruição. Pode-se dizer, conforme a interpretação de Ricoeur (2016), que nossa condição temporal de seres mortais pode ser lida "[...] como um lembrete sempre presente de que os homens, embora tenham de morrer, não nascem para morrer, mas para começar" (ARENDT, 2015, p. 305). No pensamento de Arendt, esse lembrete sempre presente poderia ser interpretado, à maneira de

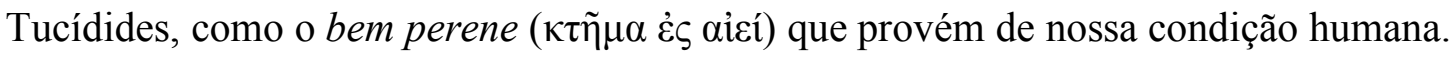

Assim, na medida em que a análise arendtiana dessas três categorias da vita activa se realiza com base em nossa condição temporal de seres mortais, pode-se afirmar, conforme Ricoeur $(2013,2016)$, que a nova investigação de Arendt em A Condição Humana traz à luz o problema da desproporção íntima de um ser temporalmente finito $e$ dotado de uma capacidade infinita de pensar - inclusive o que está fora do tempo. Embora esse não seja o problema central da antropologia filosófica, conforme Ricoeur (2013), podemos considerá-lo como um problema específico e revelador do problema acerca de quem somos nós. Para Ricoeur (2013, p. 18, tradução nossa), esse problema aponta para a estrutura antinômica do humano a qual se distende de um polo finito a outro infinito e, por isso, é preciso considerá-lo dialeticamente a partir de ambos os polos, isto é, “[...] não do limitado, mas da antinomia do limite e da ilimitação". No pensamento de Arendt, poderíamos dizer que o problema da desproporção íntima de nossa condição temporal de seres mortais deve ser visto não a partir da mortalidade, mas da antinomia do mortal e da imortalização. Desse modo, é possível explicar o porquê, para Arendt (2015), a experiência do eterno, que surge com a descoberta da contemplação pelos filósofos gregos, não pode corresponder a nenhuma atividade humana. Pois, na medida em que, conforme Arendt (2015, p. 25), “[...] a experiência do eterno é uma espécie de morte [...]”, a eternidade está fora da antinomia do mortal e da imortalização, é extrínseca à estrutura antinômica do humano. É por isto que, para Arendt (2015), a experiência do eterno só pode nos advir pela experiência do pensamento: porque é somente quando nos retiramos do mundo e nos situamos, como ego pensante, na lacuna entre o passado e o futuro ${ }^{11}$, que podemos, a partir de nossa condição temporal de seres mortais, ter a experiência da eternidade. Segundo Ricoeur (2016, p. 18, itálico do autor):

\footnotetext{
${ }^{11}$ Para Arendt (2000), esse lugar nenhum (nowhere) que estamos quando pensamos é uma lacuna (gap) no tempo, um intervalo entre passado e futuro em direção ao qual um não mais e um ainda não se dirigem. Ė somente aí, nesse lugar nenhum, que podemos ter a experiência do eterno. Contudo, não se pode perder de vista que, para Arendt, a metáfora da lacuna no tempo só faz sentido se nos referimos ao domínio dos fenômenos mentais, visto que seria absurdo usá-la para se referir ao tempo histórico ou biográfico. No prefácio de Entre Passado e Futuro (2013, p. 39) e nas últimas páginas de A Vida do Espirito - Pensar (2000, p. 158), Arendt nos adverte sobre os limites dessa metáfora.
} 
Hannah Arendt jamais se afasta dessa visão de mundo fundamental - que é tão présocrática quanto hebraica - segundo a qual a eternidade é o que nós pensamos, mas é na condição de 'mortais' que nós a pensamos.

$\mathrm{Na}$ interpretação de Ricoeur (2016, p. 18, destaque do autor), o problema da desproporção íntima do humano poderia ser colocado, de acordo com o pensamento arendtiano, nos seguintes termos: “[...] o homem é o único ser que sabe que é 'mortal', porque o homem é também o único que pensa e que pensa o que é eterno". Para Ricoeur (2013), esse problema constitui o ponto de partida da filosofia, o pressuposto pré-filosófico da filosofia. Nesse

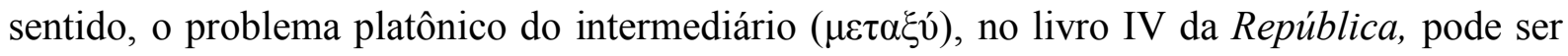
lido, segundo Ricoeur (2013, p. 19, itálico do autor, tradução nossa), como uma interpretação filosófica da linguagem do mito e do símbolo que "[...] já teria dito em enigma tudo o que o filósofo jamais poderá dizer em razão, 'claramente', tudo o que o filósofo jamais poderá trazer à lumen naturale”. Se observarmos as primeiras páginas da República (332c), é precisamente isto que Sócrates se propõe a fazer: decifrar o sentido enigmático do pensamento poético. Toda a discussão que se segue tem como ponto de partida, primeiro, os versos de Píndaro e, depois, os de Simónides. Assim, se o poeta disse em enigma ( $\varepsilon v v i ́ \xi \alpha \tau o)$ o que é a justiça, expressando-

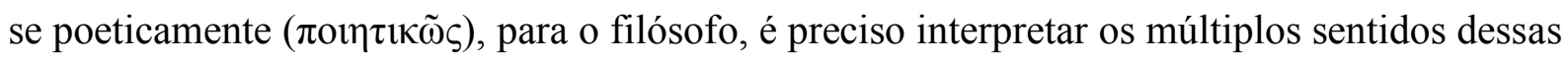
palavras que, ao mesmo tempo, mostram e ocultam (RICOEUR, 1983). A prática filosófica pode ser vista, da perspectiva socrática, como uma interpretação de si através do diálogo silencioso consigo mesmo e com os outros.

Se, conforme Ricoeur (2013), o problema da desproporção íntima do humano pode ser entendido a partir do pensamento poético, veremos mais adiante de que modo as obras de arte e os objetos da cultura podem desempenhar um papel fundamental na constituição de um alguém. Podemos adiantar aqui nosso argumento de que, no âmbito da educação, a saída para a antinomia do mortal e da imortalização repousa no modo como nos relacionamos com as obras do passado que podem permanecer no mundo através de gerações. Nesse sentido, podese afirmar que, no decorrer do processo educativo, a relação que um recém chegado estabelece consigo mesmo, no diálogo silencioso do pensamento, diante das obras e dos monumentos do passado constitui uma abertura para formular (ainda que provisoriamente) uma resposta à pergunta quem és.

Para Ricoeur (2013), o problema da desproporção íntima do humano pode ser identificado como o problema específico e revelador da antropologia filosófica, porque ele repousa justamente no modo como respondemos à pergunta quem somos nós. Poderíamos dizer que, em Arendt (2015), esse problema é colocado no modo como aparecemos para os outros, 
como revelamos nossa distinção única mediante atos e palavras em um espaço de aparência e visibilidade. A revelação do quem está implícita em tudo o que dizemos e fazemos e, assim como nosso rosto, a manifestação de nossa identidade, que se desvela através da ação e do discurso, está oculta para nós mesmos (ARENDT, 2015). É por isso que não podemos dispor do quem somos nós, tal como podemos dispor de nossas qualidades e nossos talentos, pois o quem somos nós só pode se manifestar no fluxo do agir e do falar e só aparece para o agente quando aparece para si mesmo como o herói de uma história (ARENDT, 2015). Nesse sentido, pode-se dizer que manifestamos quem somos nós, revelamos nossa identidade pessoal, toda vez que, diante dos dilemas e dos conflitos éticos que atravessam nossa existência, aparecemos uns aos outros na modalidade da ação e do discurso. Assim, conforme a análise de Arendt (2015), a ação e o discurso são os modos pelos quais respondemos à pergunta quem somos nós. É dessa maneira que aparecemos não apenas como um ser distinto, uma coisa diferente de todas as outras, mas nos revelamos como um alguém.

Partindo dessas considerações, poderíamos afirmar que toda educação digna desse nome tem de lidar com a presença de dilemas e conflitos éticos. Isso significa que o processo educativo exige, tanto do educador quanto do educando, o exercício de nossas capacidades de pensar e de julgar, isto é, de aparecer uns aos outros e exprimir nossa distinção única por meio de nossos pensamentos e juízos. Nesse sentido, poderíamos dizer que uma das principais contribuições do pensamento de Arendt para a educação consiste em explicitar o seu aspecto ético. Para os mais velhos que assumem a tarefa de educar os recém chegados, é imprescindível ajuizar de que maneira se quer apresentar o espetáculo do mundo, de qual ponto de vista o mundo de coisas interposto entre nós irá se descortinar para aqueles que, por enquanto, devem assumir a posição de espectadores. Por isso, a fim de compartilhar as coisas do mundo com os mais novos, é imprescindível o exercício de nossa capacidade de julgar. "O julgar é uma, se não a mais, importante atividade na qual esse compartilhar-o-mundo-com-outros ocorre" (ARENDT, 2013; 1961, p. 221, tradução nossa). Para Arendt (2013), sem juízos diretos, a tarefa da educação seria impossível. Ou seja, não se pode compartilhar o mundo com os mais novos se ele não for posto entre nós como algo que possuímos em comum, se ele não for colocado como algo que pode permanecer entre nós, como algo que já existia antes de nossa chegada e deve continuar a existir depois de nossa partida (ARENDT, 2015). Na educação, o mundo é visto não apenas como abrigo, mas também - e sobretudo - com assunto de seres humanos que exprimem sua distinção única através da palavra. É por meio de nossa capacidade de converter o mundo-coisa em mundo-palavra que podemos compartilhar as obras e os monumentos do passado com os recém chegados (ARENDT, 2008b). 
Para os mais novos que se encontram em processo de vir a ser, é indispensável ajuizar o que se passa no espetáculo do mundo. O exercício de nossa capacidade de julgar, avaliar e valorar as coisas do mundo que possuímos em comum pode ser visto, no âmbito da educação, como uma oportunidade na qual os recém chegados podem aparecer uns ao outros e exprimir sua distinção única. Na medida em que os mais novos se voltam atentamente para as obras e os monumentos do passado ou ao que se passa no mundo ao seu redor, isto é, que assumem a posição de espectadores, eles passam a valorar, distinguir e hierarquizar as coisas particulares com as quais entram em contato pela primeira vez ou com as quais ainda não estão suficientemente familiarizados. É neste sentido que o aspecto ético da educação se manifesta para os mais novos: cada juízo acerca dos objetos culturais que são apresentados pelos mais velhos ao longo do processo educativo requer dos mais novos uma atitude valorativa que caracteriza a posição do espectador. Ao ajuizar o que se passa no espetáculo do mundo, o espectador precisa se mover entre o certo e o errado, o feio e o belo, o bom e o ruim etc., e, ao valorar e hierarquizar algo particular como feio, bom, errado etc., um recém chegado no mundo vai paulatinamente se constituído como um alguém através de seus juízos e suas escolhas, de suas identificações e seus afastamentos (ARENDT, 2004; RICOEUR, 2013).

O leitor deve ter percebido o uso frequente da metáfora do teatro para se referir à atividade da educação, de modo que seria legítimo perguntar o que justificaria essa relação analógica entre a cena teatral e o ato educativo. Poderíamos dizer que essa relação repousa na interação que existe entre atores e espectadores. É nessa interação, sempre aberta e inacabada, que se apoia a relação educativa entre aqueles que apresentam o mundo e aqueles que buscam se familiarizar com ele. Tanto no teatro quanto na educação, para que essa interação possa ocorrer, é preciso instaurar uma distância, um afastamento que torna possível a compreensão do espectador sobre o que se passa na trama do espetáculo. No âmbito da educação, essa distância permite que o espectador percorra ativamente o espaço da cena que se abre entre os personagens, as dramatis personae que atuam no espetáculo do mundo; permite que o educando se identifique com ou se afaste desses personagens e aprenda com suas ações e com suas paixões.

A partir da teoria narrativa de Paul Ricoeur (1994), poderíamos dizer que é, nessa dialética entre distância e a aproximação, que o espectador (à maneira do leitor) pode refigurar o mundo configurado pela obra, isto é, que os mais novos podem refigurar o espetáculo do mundo que se configura no processo educativo. Para os mais novos que se encontram em processo de vir a ser, essa distância pressupõe uma disponibilidade para as coisas do mundo, pressupõe um afastamento da esfera privada da vida humana para se aproximar daquilo que 
passa a existir entre nós como algo que possuímos em comum. Nesse jogo de aproximar-se na distância e de distanciar-se na proximidade, o sujeito da educação pode modificar sua relação com o mundo e consigo mesmo (RICOEUR, 1975). Diante do espetáculo do mundo, os mais novos podem elaborar continuamente sua identidade pessoal ao longo do processo educativo.

Assim, poderíamos dizer que o uso reiterado dessa metáfora busca explicitar o modo como, na posição de espectadores, os mais novos podem se relacionar consigo mesmos diante das obras e dos monumentos do passado que constituem o mundo. E, para que o significado dessa metáfora possa fazer jus à atividade da educação conforme o pensamento de Arendt, é preciso pressupor a presença de um espectador emancipado, nas palavras de Jacques Rancière (2014), de um espectador que jamais é visto como um ser meramente passivo, hipostasiado diante do espetáculo do mundo.

\footnotetext{
O espectador também age, tal como o aluno ou o intelectual. Ele observa, seleciona, compara e interpreta. Relaciona o que vê com muitas outras coisas que viu em outras cenas, em outros tipos de lugares. Compõe seu próprio poema com os elementos do poema que tem diante de si. Participa da performance refazendo-a à sua maneira, furtando-se, por exemplo, à energia vital que esta supostamente deve transmitir para transformá-la em pura imagem e associar essa pura imagem a uma história que leu ou sonhou, viveu ou inventou. Assim são ao mesmo tempo espectadores distantes e intérpretes ativos do espetáculo que lhes é proposto (RANCIÈRE, 2104, p. 17).
}

Nesse sentido, é importante sublinhar que a posição de espectador requer uma relação ativa com o que se passa no mundo, exige o exercício de nossa capacidade de julgar. Diante dos dilemas e conflitos éticos que compõem o enredo do espetáculo do mundo, na qualidade de espectadores, os mais novos precisam inevitavelmente observar, selecionar, comparar e interpretar, precisam fazer distinções e estabelecer relações entre coisas distintas.

Em A fragilidade da bondade, Martha Nussbaum (2009) mostra que, na tragédia grega, a experiência do conflito propiciava uma espécie de aprendizado não apenas para o herói, mas também para os espectadores. Ao contrário do modelo platônico de conhecimento contemplativo, segundo Nussbaum (2009), a tragédia operava em “[...] uma via de mão dupla entre emoções e pensamentos: vemos sentimentos preparados pela memória, aprendizado causado pelo páthos". E aqui cumpre observar, com base na Poética de Aristóteles (1149b,

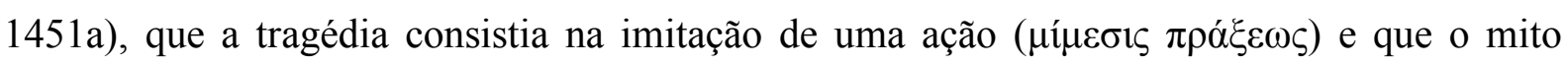
$\left(\mu v \theta_{0} \varsigma\right)$, entendido como a composição do enredo, devia conferir unidade à ação imitada. Assim, poderíamos dizer que é precisamente esse expediente mimético o que tornava possível essa espécie de aprendizado, no qual, levando em consideração o caráter e as decisões do herói, o espectador age. Isso permitia aos espectadores uma identificação com as paixões ou emoções $(\pi \alpha \theta \eta \mu \alpha ́ \tau \alpha)$ que moviam o herói no sentido de resolver o impasse colocado por uma situação 
conflituosa que, avaliada apenas do ponto de vista lógico e racional, permaneceria irresoluta (NUSSBAUM, 2009).

Nesse sentido, poderíamos dizer que, na posição de espectadores, os recém chegados têm de lidar desde muito cedo com a experiência do conflito, com a experiência de avaliar e ajuizar o que é belo e o que é feio, o que é justo e o que é injusto etc. Dessa maneira, esteja diante de situações práticas da vida cotidiana ou diante de situações vivenciadas pelos personagens de uma narrativa - que, segundo Ricoeur (2014), nunca é eticamente neutra -, os mais novos vão se familiarizando com um mundo repleto de tensões e conflitos, os quais exigirão deles um ato deliberado de aparecer por inciativa própria junto aos outros a fim de enfrentar os problemas de nosso mundo comum. Tendo em vista essas considerações, poderíamos dizer, primeiro, que a experiência do conflito é constitutiva de nossa estrutura antinômica, ou seja, está na base da desproporção íntima do humano; e, depois, que toda educação digna desse nome não deve buscar eliminá-la, mas antes propiciar aos mais novos essa espécie de aprendizado que torna possível o exercício de nossa faculdade de distinguir, de avaliar e decidir, isto é, de julgar.

Nesse sentido, é notável a importância de escolher os exemplos, de ajuizar quais personagens são dignos de compor o enredo das narrativas a partir das quais apresentamos o mundo para aqueles que ainda não estão familiarizados com ele. Se a atividade da educação consiste em apresentar o mundo aos mais novos no mundo, a familiarização com mundo não é outra coisa senão uma filiação simbólica, nas palavras de Leandro de Lajonquière (2010, p. 213), que, ao situar o sujeito da educação no campo da palavra e da linguagem, torna possível o “[...] lançar-se às empresas impossíveis do desejo". É nesse sentido que o sujeito da educação pode se identificar com os princípios de ação que movem os personagens nas narrativas que lhe vão sendo contadas ao longo do processo educativo. A escolha de personagens exemplares abre aos mais novos a possibilidade de uma filiação simbólica com as obras e os monumentos do passado. Ainda que o desdobramento do processo educativo seja imprevisível, a transmissão de marcas simbólicas permite ao sujeito da educação elaborar sua identidade pessoal no sentido de pôr-se a caminho do quem ele quer ser (LAJONQUIÈRE, 2010; ARENDT, 2015). Em outras palavras, essa filiação simbólica com os objetos culturais do passado torna possível aos mais novos habitar o mundo de outros modos. Assim, na relação educativa, podemos apresentar a justiça aos mais novos dando exemplos do que é justo; podemos apresentar a beleza aos mais novos dando exemplos de coisas belas; podemos apresentar a coragem aos mais novos dando exemplos de atos corajosos etc. Com base na Crítica do Juízo de Kant, Arendt (1992, p. 84, tradução nossa) afirma que: 


\begin{abstract}
O exemplo é o particular que contém nele mesmo, ou que supostamente contém, um conceito ou uma regra geral. Como se pode, por exemplo, julgar, avaliar, um ato corajoso? Ao julgar, uma pessoa diz espontaneamente, sem quaisquer derivações de regras gerais, 'este homem tinha coragem'. Se fosse um grego, teria nas 'profundezas de seu espírito (mind)', o exemplo de Aquiles. A imaginação é mais uma vez necessária: uma pessoa deve ter Aquiles presente mesmo que ele certamente está ausente. Se dizemos que uma pessoa é bondosa, temos no fundo de nossos espíritos o exemplo de São Francisco ou Jesus de Nazaré. O juízo tem validade exemplar desde que o exemplo seja corretamente escolhido.
\end{abstract}

Para aqueles que ainda estão se familiarizando com o mundo, a apreciação de exemplos torna possível julgar e avaliar a grandeza de um objeto ou um acontecimento particular sem padrões pré-estabelecidos. E na medida em que um recém chegado ajuíza o que se passa no espetáculo do mundo, ele valora e hierarquiza as coisas particulares com as quais entra em contato pela primeira vez ou que ainda não são suficientemente familiares. Assim, por meio da faculdade de julgar, um ser novo, que se encontra em processo de vir a ser, identifica-se com certos personagens e afasta-se de outros, e, por meio da faculdade de imaginar, poderá mantêlos presente nas profundezas de seu espírito.

Se, para Arendt (2013), o exemplo de Sócrates nos diálogos de Platão constitui a única maneira da verdade filosófica persuadir sem violar as regras do âmbito político, poderíamos dizer que, no âmbito educativo, esse exemplo constitui um modo privilegiado de fazer perguntas, inclusive aquelas que muitas vezes não possuem uma resposta. De modo geral, no âmbito educativo, desde que corretamente escolhidos, segundo Arendt (1992), os exemplos constituem um modo de apresentar aos recém chegados as paixões que movem os heróis no mundo configurado por aqueles que assumem a tarefa da educação. Em outras palavras, as ações e os discursos dos personagens exemplares que são apresentados aos mais novos no processo educativo apontam para os seus princípios inspiradores, os quais podem impulsionar o desejo de ser daqueles que ainda não são capazes de aparecer por iniciativa própria no mundo. O ensinamento pelo exemplo, segundo Arendt (2013, p. 307), “[...] é a única oportunidade de que um princípio ético seja simultaneamente verificado e validado. Assim, por exemplo, para verificar a noção de coragem, devemos recordar o exemplo de Aquiles [...]". Não obstante a predileção arendtiana pelo exemplo heroico de Aquiles $^{12}$, a fim de verificar a noção de coragem,

\footnotetext{
12 Apesar de, na interpretação de Arendt, o exemplo de Aquiles manifestar claramente a noção de coragem no mundo antigo, a partir de Platão, o exemplo de Sócrates põe em movimento essa mesma noção de outra maneira. Ao recusar a ajuda de seus amigos para escapar da condenação à morte, a coragem de Sócrates se configura nos diálogos de Platão com a mesma grandeza que a coragem de Aquiles foi configurada no poema de Homero. Ou seja, o ato corajoso de Sócrates é colocado frente a frente com o ato corajoso do herói homérico, que recusa uma vida longa para se pôr a caminho da morte gloriosa. Podemos imaginar que tanto Sócrates como Aquiles
} 
poderíamos nos dias de hoje recordar ainda o exemplo de Gandhi, Luther King, Luís Gama, Olga Benário, Dandara e Zumbi dos Palmares etc.

O que nos interessa aqui é mostrar de que maneira o exercício de nossa faculdade de julgar revela o aspecto ético da educação; indicar como os princípios que inspiram a ação e impulsionam o desejo de ser podem se manifestar, no âmbito pré político da educação, através da escolha e apreciação de exemplos. Assim, podemos apresentar aos mais novos algo que existia antes do nosso nascimento e deve permanecer no mundo depois de nossa morte; algo que transcende nossa efêmera passagem pela Terra. Ora, nesse sentido, a atividade da educação nos coloca, mais uma vez, diante de nossa condição de seres que existem no tempo e que podem pensar o que está fora dele (RICOEUR, 2013).

Embora sejamos capazes de pensar o que é eterno, isto é, possamos conceber ideias e representações que existem de modo atemporal através da experiência do pensamento, não se pode perder de vista que, na educação, a conservação de um mundo comum depende de uma atitude que sabe como cuidar daquilo que julgamos digno de permanecer no tempo (ARENDT, 2013). Essa atitude de cuidado é o que torna possível imortalizar um mundo de coisas duráveis cuja permanência no tempo depende de seres que existem sob o signo da mortalidade. É nessa tentativa de imortalizar os objetos da cultura e criar laços simbólicos com as obras e os monumentos do passado que reside, ao mesmo tempo, a grandeza e a fragilidade da educação. Toda educação digna desse nome exige, portanto, não apenas o exercício de nossa capacidade de julgar quais coisas do mundo são dignas de permanecer entre nós como algo que possuímos em comum, mas também o esforço político de conservar essas coisas que podem ser destruídas pela ruína natural do tempo ou devoradas por uma sociedade de consumidores.

Ocorre que se a imortalização é um dos polos que constituem a estrutura antinômica do humano, como vimos acima, essa tentativa não é uma tarefa que concerne apenas à atividade da educação, isto é, ela jamais pode se limitar às relações educativas que ocorrem entre aqueles que devem assumir a responsabilidade pelo mundo e aqueles que devem assumir a tarefa de renová-lo (RICOEUR, 2013; ARENDT, 2013). Na interpretação de Ricoeur (2016, p. 18, tradução nossa), “[...] a iniciativa política representa [no pensamento de Arendt] a tentativa suprema de nos 'imortalizar'”.

Insisto sobre esse ponto: seres mortais que pensam a eternidade, mas que não gozam da imortalidade, tais são esses seres que, por um projeto político, se dão a única medida de imortalidade histórica que lhes é acessível (RICOEUR, 1995, p. 16).

figurassem, para um jovem do mundo antigo, como exemplos de coragem - entre os quais um, certamente, teria sua predileção. Em Platão sob o signo de Sócrates: um novo modelo de paideía (2014), discuto mais longamente o papel educativo da figura de Sócrates nos diálogos de Platão. 
Se, no projeto filosófico de Arendt, a iniciativa política representa, para seres mortais, a tentativa suprema de imortalização, pode-se afirmar, de acordo com a interpretação de Ricoeur (2016, p. 18, tradução nossa), que "[...] é dela que resulta, ao mesmo tempo, a grandeza e a ilusão de toda iniciativa humana”. Poderíamos dizer, nesse sentido, que a iniciativa política manifesta plenamente a antinomia do mortal e da imortalização, de seres mortais que buscam se imortalizar em um mundo de coisas erigido sob o signo da mortalidade. Assim, diante dessa antinomia, a saída ilusória que a tradição de filosofia política inaugurada por Platão encontrou foi a de substituir a ação pela fabricação (ARENDT, 2015). Para os nossos propósitos, cumpre observar que a originalidade de Platão, na República (424a), consiste não tanto em modelar uma cidade ( $\pi$ ó $\lambda ı \varsigma$ ) e uma constituição ( $\pi$ o $\lambda \imath \tau \varepsilon i ́ \alpha)$, mas, precisamente, em fabricar um modelo

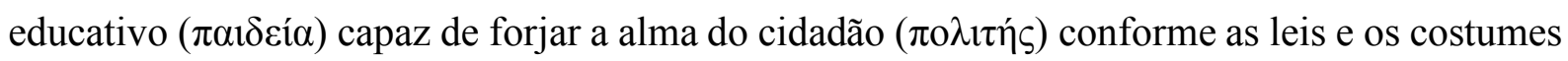
dessa cidade na qual cada um, devido à sua própria natureza, deveria executar uma única tarefa, realizar uma única função. Em outras palavras, a saída ilusória que a tradição de filosofia política inaugurada por Platão nos mostra para escapar da fragilidade dos assuntos humanos, a saber, a generalização da atividade da fabricação, não envolve apenas a ação, mas também a educação.

Contra essa saída ilusória que a filosofia política encontrou a fim de escapar da antinomia do mortal e da imortalização, é preciso observar que tanto a iniciativa política quanto a educação jamais se subordinam inteiramente às categorias de meios e fins. Ou seja, ainda que a política ou a educação seja concebida como uma atividade de caráter instrumental, é impossível assegurar que o processo em sua totalidade ocorra conforme o planejado ou que todos objetivos estabelecidos inicialmente sejam atingidos. Essa impossibilidade torna patente o caráter ilusório de conceber essas duas atividades com base nas categorias de meios e fins. É preciso pressupor a possibilidade de um controle absoluto dos processos desencadeados pelas inciativas humanas para que o filósofo pudesse construir sua bela cidade na República; para que fosse capaz de imaginar as condições de possibilidade para a fabricação, ao mesmo tempo, de uma forma de governo e seus súditos ideais. Se a tentativa de instrumentalizar a ação é, segundo Arendt (2015, p. 272), uma tentativa que busca evitar a tripla frustração da iniciativa humana, a saber, "[...] a imprevisibilidade dos resultados, a irreversibilidade dos processos e o anonimato dos autores [...]", pode-se afirmar que a tentativa de instrumentalizar a educação é igualmente uma tentativa ilusória de evitar que, a cada nascimento, um mundo novo em potencial venha a existir. 
Nesse sentido, poderíamos considerar a fragilidade daquilo que se passa entre os seres humanos como um traço comum entre a ação e a educação. Essa fragilidade pode ser vista, por um lado, como um defeito de algo que é vulnerável, débil, e, por isso, põe em risco toda inciativa humana; ou, por outro lado, pode ser vista como uma qualidade de algo incontrolável, ingovernável e, por isso, pode-se esperar que algo novo e surpreendente possa sempre acontecer entre nós. Vista sob esse aspecto, a fragilidade se converte em grandeza e aparece como um traço positivo tanto da política quanto da educação. No que concerne à iniciativa política, Ricoeur (2016, p. 27, destaque do autor, tradução nossa) afirma que, no pensamento arendtiano, a fragilidade dos assuntos humanos nos fornece:

[...] um princípio normativo que nos permite julgar o eclipse da política como expressão suprema da ação livre e condenar todas as tentativas de dissolver a política em uma atividade de engenheiro. Poder-se-ia dizer que a constituição política do Estado está para a fragilidade dos assuntos humanos, assim como a durabilidade da obra está para a natureza perecível dos produtos do trabalho.

Poderíamos estender o veredito arendtiano e condenar igualmente todas as tentativas de dissolver a educação em uma atividade de engenheiro, todas as tentativas ilusórias de controlar o processo educativo a fim de produzir um tipo ideal de ser humano, à luz uma ideia universal de homem ${ }^{13}$. A identidade pessoal e a constituição de um alguém está para a educação, assim como a fundação e a preservação de um corpo político está para a política. Se, para Arendt (2005, p. 11), “a ação, na medida em que se empenha em fundar e preservar corpos políticos, cria condições para a lembrança [remembrance], ou seja, para a história”, pode-se afirmar que a educação, na medida em que se empenha em apresentar aos mais novos as obras e os monumentos do passado, cria condições para que um ser novo elabore sua identidade pessoal e se a constitua como um alguém.

Para os nossos propósitos, é importante destacar que, para Arendt (2015), é inerente um elemento de ação a todas as atividades humanas. Na educação, pode-se dizer que esse elemento se apresenta sob um duplo aspecto. Por um lado, ao apresentar o mundo para os recém chegados, a educação oferece um inventário dos personagens e seus modos de atuar no espetáculo do mundo; de narrativas que dão profundidade à existência de seres novos que se encontram em processo de vir a ser. Desse modo, abre-se para os sujeitos da educação a possiblidade de se identificarem com atos e palavras desses personagens que passam a compor

\footnotetext{
13 Talvez, nos dias de hoje, o empreendedor de si mesmo seja a ideia universal de homem para a qual a atividade da educação tem se voltado para conformar o sujeito da educação às novas exigências de uma sociedade que, sob o ditame neoliberal de liberdade, afirma paradoxalmente aos mais novos: seja livre e resiliente, pois seu sucesso - ou seu fracasso - só depende de você! (HAN, 2017).
} 
o enredo de suas próprias estórias de vida. Nos termos da teoria narrativa de Paul Ricoeur (1994), poderíamos dizer que a educação abre a possibilidade dos mais novos configurarem suas estórias de vida mediante processos de identificação com esses personagens e enredos. E, por meio de variações imaginativas, podem refigurar seus modos de vida seguindo certos princípios de ação que podem permanecer ao longo do tempo. Para Ricoeur (2013, p. 383, itálico do autor, tradução nossa), a educação no sentido da Bildung dos iluministas e dos românticos, isto é, entendida como formação humana que vai da pedagogia até a política, pode ser considerada como "[...] o meio pelo qual se conquista essa justa distância entre os sujeitos humanos, o caminho do meio entre a identificação fusional e a separação que instaura o ódio, o desprezo e o medo".

Por outro lado, ao apresentar aos mais novos um mundo comum, o educador manifesta o elemento da ação no modo como aparece diante dos recém chegados, no modo como revela quem ele é através das escolhas e dos juízos que deve fazer diante da infinidade de coisas materiais e simbólicas que existem no mundo. Para que um mundo comum possa se abrir entre nós e os mais novos, é preciso selecionar, valorar e hierarquizar os objetos e as manifestações culturais. Pode-se afirmar que em toda relação educativa, é preciso julgar quais objetos da cultura são dignos de serem compartilhados com os mais novos, e, à medida que são apresentados aos mais novos, esses objetos são temporariamente mantidos a salvos da ruína do tempo. Por isso, para Arendt (2013), a educação é essencialmente conservadora, pois em toda relação que ocorre entre adultos e crianças está em jogo alguma coisa do mundo que desejamos proteger e abrigar. E, nesse sentido, conforme o pensamento de Arendt, que a atividade da educação se enlaça com o passado na medida em que assumimos a responsabilidade pelo mundo, que assumimos a responsabilidade pela lembrança do que passou a existir em nosso mundo comum. Talvez esse ato deliberado de rememorar as obras e os monumentos do passado seja a única medida histórica de nos imortalizar na qualidade de educadores.

Embora já tenhamos adiantado, nesse ponto, alguns traços que ação e educação possuem em comum, vejamos, agora, de que modo essa atividade que consiste em apresentar o mundo ao mais novo se relaciona com o trabalho, a obra e a ação, conforme a análise arendtiana em $A$ Condição Humana. 


\subsection{A atividade da educação entre o trabalho, a obra e a ação}

A fim de reconstruir a análise arendtiana das categorias da vita activa, seguiremos tanto a interpretação de Paul Ricoeur (1996) quanto a de Marc Le Ny (2013). Apesar das diferenças que poderíamos identificar se comparássemos as leituras de Ricoeur e Le Ny, na medida em que ambas buscam destacar o aspecto temporal daquelas atividades em que os seres humanos estão ativamente engajados no mundo, é possível considerá-las sob esse aspecto como interpretações complementares. Desse modo, buscaremos reconstruir a análise arendtiana das categorias da vita activa e mostrar de que modo a atividade da educação se relaciona, do ponto de vista temporal, com o trabalho, a obra e ação.

De acordo com Marc le Ny (2013, p. 96, tradução nossa), a ordem na qual as atividades da vita activa são analisadas por Arendt não é arbitrária, pois, de um ponto de vista fenomenológico, o trabalho não é simplesmente "[...] a primeira categoria no sumário de $A$ Condição Humana [...]”, mas aparece em primeiro lugar porque "[...] constitui uma dimensão fundamental da condição humana". Para Arendt (2015, p. 10), "o trabalho (labor) é a atividade que corresponde ao processo biológico do corpo humano". É, pois, graças ao trabalho que tanto a vida do indivíduo quanto a vida da espécie humana podem ser asseguradas. Por isso, há uma relação indissociável, de correspondência, entre trabalho e vida (ARENDT, 2015). Contudo, não se pode perder de vista que essa relação pressupõe a distinção entre bíos (ßíos), entendida

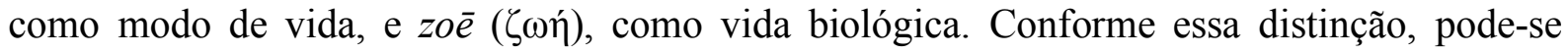
afirmar que, para Arendt (2015), a atividade do trabalho está intimamente relacionada com a vida biológica, ou seja, há uma correspondência entre, de um lado, o processo interminável de produção e consumo e, de outro, o recorrente ciclo vital de necessidade e satisfação. Nesse sentido, segundo a análise arendtiana, a temporalidade do trabalho, tal como a dos processos biológicos do nosso corpo, pode ser caracterizada por seu movimento cíclico e interminável. Assim, o trabalho é descrito como uma atividade repetitiva e incessante que consiste em renovar continuamente a vida. Segundo Marc le Ny (2013, p. 96, tradução nossa), "o trabalho é a atividade perpétua à qual a vida nos constrange, a atividade que consiste em produzir os bens que a vida exige imperiosamente o consumo perpétuo".

Os produtos do trabalho são, conforme Arendt (2015), destinados à satisfação das necessidades vitais e, mesmo que não sejam imediatamente consumidos, são devorados inexoravelmente pelo tempo. Ricoeur (1996, p. 19, tradução nossa) observa que a atividade do trabalho haure seu "[...] caráter temporal da natureza transitória das coisas produzidas em vista da subsistência”. Por isso, a principal característica dos produtos do trabalho é a ausência de 
duração, visto que são destinados ao consumo. Para Ricoeur (2016, p. 19, tradução nossa), “é o caráter consumível dos produtos do trabalho que constitui sua natureza perecível". Do ponto de vista temporal, isso significa que o trabalho obedece ao movimento cíclico da natureza. Como tudo o que é vivo, os produtos do trabalho nascem e morrem, aparecem e desaparecem, de modo que tudo se repita perpetuamente no ciclo vital ${ }^{14}$.

Para Arendt (2015), a ausência de duração caracteriza não apenas os produtos do trabalho, mas também o próprio animal laborans, cuja preocupação central aponta para a satisfação das necessidades da vida. Contudo, essa caracterização pode ser vista como paradoxal, se o caráter temporal da análise arendtiana não for realçado. Segundo Ricoeur (1996, p. 19, tradução nossa), se o trabalho é considerado desde sua produtividade, isto é, "[...] se se considera a acumulação de ferramentas e instrumentos, a constituição do capital e a abundância de mercadorias e bens na sociedade industrial avançada [...]", projeta-se sobre o trabalho os traços que caracterizam a obra. Ou seja, do ponto de vista da produtividade do trabalho, corremos o risco de situar os produtos destinados ao consumo no reino da permanência, da estabilidade e da durabilidade, conferindo mundanidade (wordliness) àquilo que se esvanece em contato com o mundo. Porém, esse paradoxo desaparece assim que o caráter temporal da análise arendtiana é explicitado. Para Ricoeur (1996), é o consumo - e não a produtividade! que caracteriza os produtos do trabalho; é o caráter consumível desses produtos que revela sua natureza perecível e efêmera.

De acordo com Marc Le Ny (2013), essa confusão moderna que amalgama trabalho e obra decorre de uma concepção ideológica do trabalho. Para Arendt (2015, p. 143), essa confusão repousa no fato de que o conceito de processo, “[...] virtualmente desconhecido antes da era moderna [...]", serviu de base tanto para a filosofia do trabalho de Marx, quanto para as teorias da evolução no século XIX. E, uma vez que o processo vital de nosso corpo se tornou o modelo desse novo conceito, “[...] a única atividade que lhe corresponde e na qual podemos traduzi-lo é a do trabalho" (ARENDT, 2015, p. 143). Nesse sentido, devido ao caráter processual que subjaz à toda atividade humana, tudo o que é realizado por seres humanos passou a ser considerado como trabalho. No projeto filosófico de Marx, segundo Arendt (2015, p. 124), a categoria do trabalho “[...] passou a ser a fonte de toda produtividade e a expressão

\footnotetext{
${ }^{14}$ Em seu artigo Hannah Arendt and the ordinance of time, publicado na revista Social Reserch, em 1977, Sheldon Wolin destaca a importância da temporalidade do trabalho na análise arendtiana do mundo moderno. O autor destaca que a oposição entre trabalho e ação política, na inversão moderna da ordem hierárquica das atividades humanas, resultou no triunfo de uma mentalidade do trabalho (laboring mentality).
} 
de toda humanidade do homem”. É nesse sentido que, conforme Le Ny (2013, p. 103, tradução nossa):

O conceito econômico do trabalho é um conceito ideológico. Para afirmar que o trabalho é o nome de toda atividade humana, é preciso reduzi-lo a essa generalidade oca: é um 'poder-de-produzir', uma produtividade social abstrata.

Segundo a interpretação de Le Ny (2013, p. 104, tradução nossa), na medida em que "[...] o trabalho se torna o termo genérico de toda atividade considerada como socialmente útil [...]”, tudo o que não interessa à vida ou o que não é necessário ao processo vital perde sua dignidade própria e passa a ser visto como algo determinado pelas relações sociais que são estabelecidas em um modo de produção específico. Por isso, quando a vida se torna a preocupação humana central e, o trabalho, a expressão de toda humanidade do homem, o último vestígio de ação que é inerente a todas as atividades humanas desaparece do mundo (ARENDT, 2015). O que nos interessa aqui é destacar, conforme a análise arendtiana, o caráter não mundano da atividade do trabalho e a ausência de duração de seus produtos. Segundo Arendt (2015, p. 145):

\footnotetext{
Os produtos do trabalho, produtos do metabolismo do homem com a natureza, não permanecem no mundo tempo suficiente para se tornarem parte dele, e a própria atividade do trabalho, concentrada exclusivamente na vida e em sua manutenção, esquece-se do mundo até o extremo da não mundanidade.
}

Se os produtos destinados ao consumo são essenciais para a manutenção da vida, é preciso considerar que, para Arendt (2015), a atividade do trabalho se apresenta sob um duplo aspecto: por um lado, para que as necessidades do nosso corpo possam ser satisfeitas, o trabalho requer uma dose de fadiga e esforço físico, de dor e exaustão; por outro, tendo sido satisfeitas as necessidades do nosso corpo, proporciona uma parcela de alegria e satisfação, de prazer e felicidade. Para Arendt (2015), a felicidade só pode existir como consequência do estar vivo, visto que é concomitante ao processo de manutenção da vida. Segundo Arendt (2015, p. 133):

\footnotetext{
Não existe felicidade duradoura fora do ciclo prescrito de exaustão dolorosa e regeneração prazerosa; e tudo o que desequilibra esse ciclo - a pobreza e a miséria nas quais a exaustão é seguida pela penúria ao invés da regeneração, ou grande riqueza e uma vida inteiramente isenta de esforço na qual o tédio toma o lugar da exaustão e os moinhos da necessidade, do consumo e da digestão trituram até a morte, impiedosa e esterilmente, um corpo humano impotente - arruína a felicidade elementar que advém de se estar vivo.
}

Pode-se afirmar, tendo por base a análise arendtiana, que os produtos do trabalho são necessários para a manutenção da vida, mas não suficientes para que seres humanos habitem a superfície terrestre. É preciso erigir um mundo de coisas artificiais a fim de abrigar a fragilidade 
de nosso corpo e a efemeridade de nossa vida. Nesse ponto, na transição do trabalho para a obra, de acordo com a análise arendtiana, poderíamos nos perguntar de que modo a educação se relaciona com essa atividade que corresponde à vida. Se, como vimos, o educar consiste em apresentar aos mais novos um mundo de coisas interposto entre nós, poderíamos equivocadamente supor que não houvesse, no pensamento de Arendt, nenhuma relação entre trabalho e educação. Embora tenhamos ressaltado até aqui a relação com o mundo, para Arendt (2013), a educação consiste também na relação com a vida. Conforme Arendt (2013), essa dupla relação - com o mundo e com a vida - corresponde ao duplo aspecto sob o qual os mais novos aparecem para aqueles que assumem a tarefa de educá-los. A criança, o sujeito da educação, aparece para o educador como um ser humano novo, que é inserido pelo nascimento em um mundo sempre mais velho do que ele, e, ao mesmo tempo, como um ser humano em estado de vir a ser (ARENDT, 2013). Se não fosse a novidade que vem ao mundo a cada nascimento, se a criança não fosse nova em relação ao mundo que já existia antes de seu nascimento e que deve continuar existindo depois de sua morte, segundo Arendt (2013, p. 235):

[...] a educação seria apenas uma função da vida e não teria que consistir em nada além da preocupação para com a preservação da vida e do treinamento e prática no viver que todos os animais assumem em relação a seus filhos. Os pais humanos, contudo, não apenas trouxeram seus filhos à vida mediante a concepção e o nascimento, mas simultaneamente os introduziram em um mundo.

Assim, para Arendt (2103), a atividade da educação consiste em uma dupla relação com a vida e com o mundo; com a novidade que vem ao mundo a cada nascimento e com a potencial imortalidade das coisas que podem permanecer ao longo de gerações. É nesse sentido que a atividade da educação exprime uma dupla relação de cuidado; de amor ao mundo de coisas materiais e simbólica que existe entre nós e, ao mesmo tempo, de amor à novidade que vem ao mundo com a chegada de cada ser novo que, como um milagre, eclode de modo inesperado e pode mudar o curso automático do que se passa no mundo. Isso significa que a atividade da educação jamais se limita ao crescimento e desenvolvimento de um ser vivo. Caso contrário, a maturação biológica poderia ser considerada a meta de todo ato educativo. Por outro, não se pode negligenciar que o cuidado para com as necessidades do corpo de seres novos que acabam de chegar no mundo é parte constitutiva da educação. No caso de bebês e crianças bem pequenas, o ato educativo abrange o sono, o banho, a alimentação, a higiene etc. E na medida em que, para Arendt (2013), a atividade da educação se relaciona, ao mesmo tempo, com a vida e com o mundo, pode-se afirmar que seu caráter conservador se volta tanto para a vida de seres novos quanto para um mundo de coisas velhas. Dessa maneira, a educação tem de lidar, ao mesmo tempo, com os produtos do trabalho que visam a satisfação das necessidades da vida e 
com as obras e os monumentos do mundo que conferem estabilidade e confiança para a morada de seres mortais na Terra.

Tendo feito essas considerações sobre a atividade da educação, voltemos à análise arendtiana das categorias da vita activa. Para Arendt, o caráter efêmero dos produtos do trabalho está para a vida, assim como o caráter durável da obra está para o mundo. Ao contrário dos produtos do trabalho que são destinados ao consumo, os produtos do artifício humano são destinados ao uso (exceto as obras de arte e os objetos da cultura, como veremos adiante). Para Ricoeur (2016, p. 20, tradução nossa), "a diferença entre consumo e uso tem uma conotação tipicamente temporal. Ela marca a distância entre passar e durar, entre mudar e perseverar". Essa diferença não é, para Arendt (2015), uma diferença de grau, mas de natureza. Segundo Arendt (2015, p. 171):

Se, por exemplo, concebermos a natureza dos objetos de uso em termos das roupas
que vestimos, seremos tentados a concluir que o uso é apenas um consumo em passo
mais lento. Contra isso há o argumento, já mencionado, de que a destruição, embora
inevitável, é incidental em relação ao uso, mas inerente ao consumo. O que distingue
o mais frágil par de sapatos dos meros bens de consumo é que ele não se estragará se
não for usado, o fato de que tem certa independência própria, ainda que modesta, que
lhe permite sobreviver, até por um tempo considerável, aos estados de ânimo
cambiantes de seu proprietário. Usados ou não, permanecerão no mundo durante certo
tempo, a não ser que sejam intencionalmente destruídos.

E aqui podemos ver de outra perspectiva o paradoxo que surge da indistinção entre trabalho e obra. Se o caráter temporal dos produtos do trabalho e da obra não forem considerados, na medida em que os objetos fabricados por mãos humanas (como, por exemplo, roupas, sapatos, casas, templos, pinturas, poemas etc.) dependem da mediação do trabalho e do uso de ferramentas para sua produção e manutenção, poderíamos concluir equivocadamente que tanto os bens de consumo quanto os objetos de uso estariam igualmente condenados à destruição. E, nesse caso, tanto os produtos do trabalho quando os produtos do artifício humano seriam vistos como produtos destinados ao consumo. Para Ricoeur (2016, p. 21, destaque nosso, tradução nossa), “[...] o paradoxo se dissipa desde que se considere de mais perto os traços temporais, não da produção, mas do consumo e do uso, isto é, da maneira como nós mesmos nos relacionamos com os produtos do trabalho e da obra". Portanto, pode-se afirmar que a permanência da obra em no mundo depende do modo como nos relacionamos com as coisas fabricadas por mãos humanas. Ou seja, a permanência de algo durável no mundo depende de uma modalidade específica de relação, de uma atitude que sabe como cuidar das coisas do mundo a fim de que elas não desapareçam. 
Por isso, não basta simplesmente que objetos fabricados por mãos humanas sejam destinados ao uso para que eles permaneçam no mundo. De acordo com Le Ny (2013, p. 128, tradução nossa), “[...] a durabilidade é, pois, a condição da permanência”. Se a durabilidade dos objetos de uso é o que torna possível edificar um mundo que seja capaz de transcender nossa efêmera passagem pela Terra, é preciso estabelecer para com eles uma relação de cuidado. "Sem essa transcendência em uma potencial imortalidade terrena, nenhuma política, no sentido restrito do termo, nenhum mundo comum nem domínio público são possíveis" (ARENDT, 2015, p. 67). Nesse sentido, para Arendt (2015), essa atitude que sabe como cuidar das coisas do mundo está vinculada à preocupação humana com a imortalidade. E, embora sejamos inseridos pelo nascimento em um mundo erigido por seres mortais, ele somente poderá sobreviver ao ir e vir de gerações, se, conforme Arendt (2015), houver um espaço público no qual seja possível abrigar as coisas mundanas que possuímos em comum a fim de protegê-las contra a futilidade da vida. "É a publicidade do domínio público que pode absorver e fazer brilhar por séculos tudo o que os homens venham a querer preservar da ruína natural do tempo" (ARENDT, 2015, p. 68).

Para os nossos propósitos, é oportuno sublinhar que essa atitude de cuidado para com as coisas do mundo, esse amor às coisas mundanas, está diretamente relacionada com a atividade da educação. Vimos acima que, para Arendt (2013), a educação é essencialmente conservadora na medida em que consiste em uma dupla relação com a vida e com o mundo; em uma dupla atitude de cuidado para com a novidade que vem ao mundo a cada nascimento e para com as obras e os monumentos do passado. Isso significa que a atividade da educação busca abrigar algo do mundo que julgamos digno de permanecer depois de nossa morte. E para que um mundo de coisas permaneça entre nós, para que transcenda nossa efêmera passagem pela Terra, a educação assume um papel importante, sem jamais substituir o lugar da iniciativa política. Para Arendt (2013, p. 234), “a educação está entre as atividades mais elementares e necessárias da sociedade humana, que jamais permanece tal qual é, porém se renova continuamente através do nascimento, da vinda de novos seres humanos".

Ocorre que, para Arendt (2015), mesmo as coisas duráveis, que tornam o mundo humano uma morada mais estável para os seres mortais na Terra, podem ser destruídas pelo apetite pantagruélico de uma sociedade de consumidores. De acordo com o diagnóstico arendtiano da era moderna, a emancipação do trabalho, a qual se deu muito antes da emancipação política dos trabalhadores, é igualmente a emancipação do consumo (ARENDT, 2015). Assim, o surgimento de uma sociedade de trabalhadores só foi possível na medida em o trabalho passou a ocupar o posto mais elevado na hierarquia das atividades humanas. Para 
Arendt (2015), como produção e consumo são dois estágios do mesmo processo, uma sociedade de trabalhadores é, ao mesmo tempo, uma sociedade de consumidores. E uma das consequências do advento de uma sociedade de consumidores é que as coisas mundanas e duráveis passam a ser consideradas como bens fungíveis e perecíveis e, desse modo, as coisas que poderiam conferir alguma estabilidade e permanência ao mundo humano precisam ser consumidas na mesma velocidade em que são produzidas.

De acordo com Arendt (2015, p. 166), uma sociedade de consumidores está baseada em “[...] uma economia do desperdício, na qual todas as coisas devem ser devoradas e descartadas quase tão rapidamente quanto aparecem no mundo, a fim de que o processo não chegue a um fim repentino e catastrófico". Nesse sentido, a tarefa da educação se torna paradoxal. Pois, em uma sociedade de consumidores, a atividade da educação é concebida em vista do trabalho. Isso significa que todas as coisas que existem no mundo passam a ser avaliadas em vista das necessidades da vida e das exigências da sociedade. Porém, se a educação é essencialmente conservadora, isto é, se consiste em apresentar aos mais novos aquelas coisas materiais e simbólicas que julgamos dignas de permanecer no mundo, como é possível educar os recém chegados em uma sociedade de consumidores, na qual todas as coisas devem ser consumidas tão rapidamente quanto são produzidas? Como é possível conservar um mundo de coisas através de gerações, se, na lógica da produção e do consumo, tudo o que existe passa a ser visto como algo obsoleto que precisa ser imediatamente descartado e substituído por algo novo?

De acordo com o pensamento de Arendt, poderíamos responder a essas perguntas afirmando que é precisamente o modo como nós nos relacionamos com as coisas do mundo que permite à educação resistir ao apetite pantagruélico de nossa sociedade de consumidores. É essa atitude que sabe como cuidar das coisas que julgamos dignas de permanecer no tempo, o amor mundi, que permite à educação escapar da voracidade irrefreável que caracteriza a lógica da produção e do consumo. Sem essa atitude de cuidado que pode fazer frente à tendência de substituir as coisas mundanas por outras sempre mais novas, é como se a própria atividade da educação fosse tragada pelo processo interminável de produção e consumo; é como se, junto das demais coisas artificiais que poderiam conferir estabilidade ao nosso mundo, a educação se tornasse um bem fungível a serviço das necessidades da vida e da sociedade - e talvez o melhor exemplo de como a educação pode se curvar diante da lógica da produção e do consumo seja pensar o processo educativo com base no desenvolvimento de habilidades e competências, as quais podem ser a todo momento substituídas por outras, em conformidade com as exigências de uma sociedade em constante transformação. Nesse caso, a educação busca esconder seu aspecto ético para revelar, em primeiro lugar, seu aspecto técnico. E se, para Arendt (2013), a 
educação é o ponto no qual decidimos se amamos o mundo o suficiente para assumirmos a responsabilidade por ele, toda educação digna desse nome deve manifestar claramente seu aspecto ético. Desse modo, quando a educação assume, antes de tudo, a tarefa de preparar os mais novos para as exigências de uma sociedade de consumidores, a responsabilidade pelo mundo é banida do âmbito educativo. Segundo Arendt (2015, p. 155):

Em nossa necessidade de substituir cada vez mais depressa as coisas mundanas que nos rodeiam, já não podemos nos permitir usá-las, respeitar e preservar sua inerente durabilidade; temos de consumir, devorar, por assim dizer, nossas casas, nossa mobília, nossos carros, como se estes fossem as 'coisas boas' da natureza que se deteriorariam inaproveitadas se não fossem arrastadas rapidamente para o ciclo interminável do metabolismo do homem com a natureza. É como se houvéssemos rompido à força as fronteiras distintivas que protegiam o mundo, o artifício humano, da natureza, tanto o processo biológico que prossegue dentro dele quanto os processos naturais cíclicos que o rodeiam, estragando-lhes e abandonando-lhes a sempre ameaçada estabilidade de um mundo humano.

Enquanto pudermos lembrar dessas fronteiras que protegiam as coisas mundanas, as quais podem permanecer através de gerações e resistir ao movimento sempre recorrente da natureza que traga tudo para dentro de si, temos o direito de esperar que a atividade da educação possa, mesmo em uma sociedade de consumidores, escapar da lógica da produção e do consumo. Enquanto não nos esquecermos de que a permanência e a estabilidade de nossa morada humana na Terra dependem de uma relação de cuidado com as coisas do mundo, temos o direito de esperar que a atividade da educação possa conservar aquilo que julgamos digno de ser mantido a salvo da ruína do tempo.

Se, como vimos, o que permite edificar um mundo são os produtos do artifício humano, os quais podem conferir estabilidade e confiança para a morada de seres mortais na Terra, esse mundo antrópico ${ }^{15}$, nas palavras de Marc Le Ny (2013), é a condição de possibilidade para que exista um espaço no qual os seres humanos possam aparecer uns aos outros na modalidade da ação e do discurso. E aqui nos colocamos a caminho da última categoria da vita activa analisada por Arendt em A Condição Humana. Segundo Ricoeur (1996, p. 22, tradução nossa):

Com efeito, a transição entre obra e ação é assegurada por aquela reminiscência, considerada como uma estrutura da própria obra. As obras enquanto tais são os documentos e os monumentos do passado. Elas testemunham a diferença entre o tempo como duração e o tempo como passagem. Se temos em mente essa polaridade

\footnotetext{
${ }^{15}$ A expressão mundo antrópico traduz o conceito de mundo em Arendt. Do ponto de vista heurístico, ela tem a vantagem de nos fazer perceber que, por um lado, o mundo erigido pelo artifício humano se apresenta de diversos modos e, por outro, que esses modos de erigir e habitar o mundo ocorrem ao longo do tempo para se sedimentarem como paisagens que existem graças à presença de seres humanos. Segundo Marc Le Ny (2013, p. 129), "distinto do universo natural, físico e biológico, o mundo antrópico é o mundo artificial, material e humano. O homo faber é kosmothetes. Propomos a expressão 'mundo antrópico' para nomear o conceito de mundo arendtiano nessa primeira acepção. O adjetivo ‘antrópico’ é importado do vocabulário geológico que serve para nomear as paisagens devidas à atividade humana (ou neo-paisagens)".
} 
entre durar e passar, sem considerar as mudanças sociais e culturais que tentam apagar as diferenças entre obra e trabalho, a referência ao tempo como passagem se mantém como a marca do trabalho e a referência ao tempo como duração, a marca da obra.

Antes de seguir com a ação, é notável que, mais uma vez, a interpretação de Ricoeur sublinhe o caráter temporal da análise arendtiana a fim de destacar as transições entre, por um lado, a obra e ação, e, por outro, o trabalho e a obra. Essa polaridade entre passar e durar, entre o tempo como passagem e o tempo como duração, é precisamente o que distingue a temporalidade dos seres naturais que nascem, crescem, se reproduzem, definham e morrem, e a temporalidade dos objetos artificiais que interrompem o movimento sempiterno da natureza e, por isso, podem existir por mais tempo no mundo que a vida de seus artífices. Assim, a polaridade entre durar e lembrar, entre o tempo como duração e o tempo como lembrança, é precisamente o que distingue a mundanidade dos objetos artificiais e a fragilidade dos assuntos humanos.

Para os nossos propósitos, é importante observar que, dentre todas as coisas mundanas fabricadas por seres mortais, dentre todos os documentos e monumentos do passado que constituem nosso mundo comum, para Arendt (2015), as obras de arte se destacam por sua excepcional permanência. E se, como vimos, a durabilidade é a condição da permanência, é como se a durabilidade da obra de arte fosse de uma ordem superior às demais coisas duráveis que existem no mundo (ARENDT, 2015). Ao contrário dos objetos que são fabricados com vistas a algum fim, que existem em função de alguma utilidade, as obras de arte não são destinadas ao uso e, a despeito de sua inutilidade, são coetâneas do aparecimento dos seres humanos na Terra. Segundo Arendt (2015, p. 208), desde que alcancem o seu lugar adequado no mundo, as obras de arte podem aspirar à imortalidade e, assim, “[...] alcançar a permanência através de eras".

Contudo, para que existam na qualidade de obras de arte, é preciso que elas apareçam e sejam julgadas à luz do mundo público ${ }^{16}$, tendo em vista sua beleza. Se, para Arendt (2013), tudo o que existe no mundo deve aparecer, as obras de arte são as únicas coisas mundanas que são essencialmente destinadas a aparecer e ser belas. É precisamente o fato de que as obras de arte existem no mundo como coisas inúteis que permite que elas possam ser julgadas

\footnotetext{
16 Isso não significa que somente as obras de arte devam ser julgadas à luz do mundo público. Todo juízo, para que seja válido, depende da presença de outros, pois sua validade específica repousa em um acordo potencial não com si mesmo, como ocorre no diálogo silencioso do pensamento, mas com os outros (ARENDT, 2013). "É verdade que um objeto comum de uso não é nem deve ser destinado a ser belo; no entanto, tudo o que possui alguma forma e é visto não pode deixar de ser belo ou feio. Tudo o que existe aparece necessariamente, e nada pode aparecer sem ter forma própria; portanto, não existe de fato coisa alguma que não transcenda o seu uso funcional, e essa transcendência, sua beleza e sua feiura, corresponde ao seu aparecimento público e ao fato de ser vista [por uma pluralidade de espectadores]" (ARENDT, 2015, p. 215).
} 
exclusivamente por sua aparência e beleza. Assim como o poder que surge quando os homens agem em conjunto desaparece no momento em que eles se dispersam, uma obra de arte somente pode aspirar à imortalidade quando é separada do contexto no qual os objetos são comumente usados (ARENDT, 2015). Pois, para Arendt (2015), somente quando esses objetos que reificam a capacidade humana de pensar podem aparecer e ser julgados segundo critérios objetivos do mundo é que eles podem ser salvaguardados das exigências da vida diária.

Ainda que a beleza seja o único critério a partir do qual o juízo estético pode julgar uma obra de arte, nenhum objeto fabricado por mãos humanas pode ser julgado simplesmente por sua utilidade (ARENDT, 2015). Mesmo aqueles objetos que são destinados ao uso, sua mera existência, seu mero aparecimento no mundo, transcende a esfera da pura instrumentalidade. Ou seja, mesmo aquelas coisas que não são essencialmente destinadas a aparecer e ser belas podem ser julgadas e avaliadas por sua forma e beleza. Portanto, mesmo um mero objeto de uso, na medida em que aparece no mundo, tem o direito de ser julgado não "[...] segundo as necessidades subjetivas do homem, mas segundo critérios objetivos do mundo onde encontrarão o seu lugar para durar, para serem vistos e para serem usados" (ARENDT, 2015, p. 215-16).

Além disso, as obras de arte nos fazem pensar o modo como cada grupo ou sociedade se relaciona com o mundo, pois elas são os únicos objetos que podem resistir e sobreviver ao perpétuo processo vital dos seres mortais que o habitam. E, para Arendt (2013), é só quando essa sobrevivência é asseverada que se pode falar em cultura. Desse modo, conforme Arendt (2013), o fenômeno da arte deve ser o ponto de partida para uma discussão sobre a cultura, pois obras de arte são, por excelência, objetos culturais. Nesse sentido, uma discussão sobre a educação deveria partir do modo como nos relacionamos com os objetos da cultura e, particularmente, com as obras de arte. E aqui é oportuno sublinhar, à luz do pensamento arendtiano, o vínculo entre educação e cultura. Para Arendt (2013), o significado originário da palavra "cultura" (do latim, colere) estava ligado ao preparo da terra, tanto no sentido de cultivar a natureza quanto de torná-la um lugar habitável. Só posteriormente, com a expressão ciceroniana cultura animi, a palavra "cultura" passou a significar o preparo do espírito, o cultivo da alma. Assim, segundo Arendt, (2013), quando falamos ainda hoje em cultura, pensamos, conjuntamente, no ato de cultivar natureza a fim de torná-la um lugar habitável para seres humanos $e$ na atitude de cuidado para com as obras e os monumentos do passado. 
mundanas das coisas, as obras de artistas, poetas, músicos, filósofos e daí por diante (ARENDT, 2013, p. 267).

É, portanto, nessa atitude que sabe como cuidar das coisas do mundo que repousa o vínculo entre educação e cultura. À medida que os mais novos vão se familiarizando com as obras de artistas, poetas, músicos, filósofos etc., abre-se para eles um novo mundo de coisas velhas; um mundo comum no qual os recém chegados se inserem através da linguagem. Para aqueles que acabam de chegar no mundo, familiarizar-se com as coisas mundanas é, em primeiro lugar, familiarizar-se com a palavra. Segundo Étienne Tassin (1991, p. 34, tradução nossa):

O mundo não é comum se não for instituído simbolicamente como comum na palavra, na articulação dos topoi, dos lugares comuns e dos discursos, pelos quais as línguas se encontram, se agenciam e nos quais se marcam sua irredutível diferença tanto quanto a comunidade do mundo que torna a palavra possível e sensata.

Nesse sentido, pode-se afirmar que, no processo educativo, o cultivo das artes e das humanidades possibilita a abertura e a conservação de um mundo comum no qual os mais novos, inseridos e inserindo-se no campo da palavra, podem exercitar esse modo de relação que sabe como cuidar das coisas menos úteis e mais mundanas que existem entre nós. É aí, no espaço simbólico da linguagem, que o mundo passa a interessar à atividade da educação, isto é, ao se tornar "[...] na acepção mais literal da palavra, algo que inter-essa [inter-est], que se situa entre as pessoas e que, portanto, é capaz de relacioná-las e mantê-las juntas" (ARENDT, 2015, p. 266). Pode-se dizer que, na educação, o mundo de coisas erigido por mãos humanas como abrigo de seres mortais se converte em assunto e, como algo que possuímos em comum, passa a interessar tanto os mais novos quanto os mais velhos.

Diante de uma obra de arte, segundo Arendt (2013), podemos ter certo pressentimento de imortalidade. Para seres novos que acabam de chegar no mundo, essa experiência pode ser vista como uma abertura para as heranças culturais do passado (RICOEUR, 1975). "É como se a estabilidade mundana se tornasse transparente na permanência da arte, de sorte que certo pressentimento de imortalidade [...] tornou-se tangivelmente presente para fulgurar e ser visto, soar e ser escutado, falar e ser lido" (ARENDT, 2015, p. 209). Nesse sentido, a experiência de deter-se diante de uma obra de arte e confrontar-se com ela pode desempenhar um papel fundamental na constituição de um alguém, pois esses objetos culturais que são capazes de prender nossa atenção e nos comover podem modificar não apenas o modo como vemos o mundo, mas também a maneira como queremos aparecer nele. Assim, se ao longo do processo educativo o contato com obras de arte pode suscitar uma profunda mudança no modo de relação que os mais novos estabelecem com o mundo e com si mesmos, pode-se afirmar, conforme 
José Sérgio de Carvalho (2017), que esse encontro pode propiciar uma autêntica experiência formativa. Segundo Carvalho (2017, p. 27, itálico do autor):

\begin{abstract}
Uma experiência torna-se formativa por seu caráter afetivo: um livro que lemos, um filme a que assistimos ou uma repreensão nos afeta e, assim, transforma e, em nós, abre uma nova forma de relação com o mundo. Trata-se, pois, de um encontro entre um evento mundano, um objeto da cultura e um sujeito que, ao se aproximar de algo que lhe era exterior, caminha no sentido da constituição de um ser singular em meio a um mundo comum.
\end{abstract}

É certo que poderíamos, cada um de nós, nos lembrar de pelo menos um desses encontros por meio dos quais, afetados por um objeto cultural, passamos a ver o mundo e a nós mesmos de modo diverso. É possível ainda que a maioria desses encontros tenha ocorrido enquanto frequentávamos a escola. $\mathrm{E}$ o fato de que esses encontros, embora sejam imprevisíveis, ocorram com certa frequência ao longo do processo educativo, talvez fosse dispensável de qualquer exemplo. Porém, gostaria de registrar aqui uma dessas experiências formativas - e, de algum modo, manifestar minha gratidão ao professor Vidal Bezerra da Silva, quem me apresentou ao poeta Carlos Drummond de Andrade. No fim da década de 1990, era estudante de uma escola pública localizada na periferia da zona norte paulistana. Como, na E.E.P.S.G. Tito Prates da Fonseca, o uso de uniforme não era obrigatório, havia entre nós, adolescentes, uma tendência (uma moda!) de se vestir como surfistas ou skatistas, mesmo que nunca tivéssemos pisado em uma prancha ou um skate. Daí era comum o uso de camisetas estampadas e bermudas coloridas cujas marcas disputavam o espaço de nossos corpos. Foi quando, em uma aula de língua portuguesa, lemos o poema Eu, etiqueta. Diante daqueles versos, daquele homem-anúncio itinerante, era como se tivesse sofrido uma ecdise e minhas roupas não me servissem mais. Era incomodo vesti-las.

$\mathrm{Na}$ qualidade de educadores, de quem assume a responsabilidade pela conservação das coisas mundanas e pela novidade que vem ao mundo a cada nascimento, poderíamos nos perguntar quais objetos culturais possuem essa capacidade de transformar uma mera aprendizagem em uma experiência formativa. A resposta mais razoável a essa pergunta - e talvez a única possível - repousa no exercício de nossa capacidade de julgar, de avaliar e ajuizar quais obras de arte e objetos da cultura são dignos de permanecer entre nós. Nesse sentido, se para Arendt (2013), o critério adequado para julgar uma obra de arte é a beleza, a escolha desses objetos culturais que podem transformar uma mera aprendizagem em uma experiência formativa deveria ser realizada com base nesse mesmo critério. Segundo Arendt (2013, p. 263): 


\begin{abstract}
por sua aparência - isto é, por serem belos, feios ou algo de intermediário -, teríamos de arrancar fora nossos olhos. Contudo, para nos tornarmos cônscios das aparências, cumpre primeiro sermos livres para estabelecer certa distância entre nós mesmos e o objeto, e quanto mais importante é a pura aparência de uma coisa, mais distância ela exige para sua apreciação adequada. Tal distância não pode surgir a menos que estejamos em condições de esquecer a nós mesmos, as preocupações, interesses e anseios de nossas vidas, de tal modo que não usurpemos aquilo que admiramos, mas deixamo-lo ser tal como o é, em sua aparência.
\end{abstract}

Para os nossos propósitos, é importante destacar que esse esquecimento de nossos interesses privados, de nossas preocupações individuais e necessidades vitais é a condição de possibilidade para instaurar uma distância que nos permite interpretar os múltiplos sentidos dessas coisas mundanas cuja essência é aparecer e ser belas (RICOEUR, 1983). Essa distância é, portanto, o que torna possível, ao mesmo tempo, um afastamento do eu (self) e uma aproximação das obras e dos monumentos do passado. Nesse sentido, a atividade da educação consiste em alargar o horizonte no qual os mais novos podem se situar a fim de compreender, sem preconceitos e com atenção, os objetos culturais e a si mesmos. Para Ricoeur (1975), essa distância se torna uma distância produtiva na medida em que, no movimento da interpretação, o intérprete se esforça em compreender as heranças culturais do passado a fim de se apropriar daquilo que lhe é estranho. Segundo Ricoeur (1975, p. 39), a dialética entre apropriar-se do que é estranho e estranhar o que é próprio é inerente ao círculo hermenêutico da interpretação, isto é, “[...] a tensão entre o 'próprio' e o ‘estranho' faz parte da interpretação pela qual tentamos aplicar-nos a nós mesmos o sentido singular de uma tradição determinada”. Ou seja, ao instaurar uma distância do eu, abre-se a possibilidade de uma aproximação de si mesmo diante de diferentes heranças culturais do passado (RICOEUR, 1975).

Cabe perguntar, aqui, que papel essa distância produtiva pode desempenhar na educação. Em outras palavras, como essa tensão entre o que é próprio e o que é estranho pode contribuir na constituição de um alguém? O exercício dessa capacidade de instaurar uma distância entre nós e as coisas do mundo torna possível não apenas decifrar os múltiplos sentidos dos objetos culturais, mas também nos permite compreender nosso lugar próprio no mundo (ARENDT, 2005). Para os mais novos, essa distância torna possível ajuizar a beleza das coisas menos úteis e mais mundanas que existem entre nós, permite que eles se apropriem das heranças culturais do passado e, desse modo, alarguem seus pontos de vista sobre o mundo e si mesmos. É essa função hermenêutica da distância, nas palavras de Ricoeur (1986), que torna possível deslocar nossa atenção do $e u$ para esse mundo de coisas que, no processo educativo, vai se tornando cada vez mais familiar até se revelar como algo que possuímos em comum.

Se observamos o movimento do texto na composição de $A$ Condição Humana, podese afirmar que a reflexão sobre a obra de arte é precisamente o ponto de articulação entre a obra 
e a ação. É como se Arendt nos lembrasse de que o aparecimento público fosse a condição para aquele tipo de permanência por meio da qual não apenas as obras de arte, mas também os assuntos humanos podem aspirar a uma potencial imortalidade. $\mathrm{O}$ fato de que as coisas fabricadas por mãos humanas podem durar por mais tempo que a breve passagem de seus fabricantes pela Terra e, sob certas condições, podem permanecer no mundo através de gerações, nos permite entrever a significação trágica de nossa condição temporal de seres mortais.

No pensamento de Arendt, o nascimento e a morte de seres humanos não são meramente fenômenos biológicos, uma vez que “[...] nascer é ingressar em um mundo durável, ao invés de simplesmente surgir no seio da repetição sempiterna da natureza; e morrer é se retirar de um tal mundo durável” (RICOEUR, 1996, p. 22, tradução nossa). Não obstante a significação trágica que envolve o evento do nascimento e da morte de um ser humano, ela não se restringe ao início e ao fim de uma biografia individual, mas se desdobra ao longo de todo o enredo de uma estória singular de vida. Nesse sentido, a significação trágica pode ser lida como a marca indelével de nossa condição humana. Conforme as análises de Adriano Correia (2011), essa significação trágica se manifesta de maneira mais intensa quando nos inserimos por iniciativa própria no mundo, quando aparecemos uns aos outros mediante atos e palavras e iniciamos algo novo no mundo.

\subsection{Agir, educar e narrar}

A significação trágica de nossa condição temporal de seres mortais aponta para a contingência dos assuntos humanos, a qual obsta qualquer tentativa de efetivamente instrumentalizar nossos atos e nossas palavras. Isso implica, com efeito, na impossibilidade tanto de prever as ações humanas, quanto de controlar suas consequências (RICOEUR, 1996; CORREIA, 2011). Se os produtos destinados ao uso são fabricados através de uma cadeia interminável de meios e fins, os produtos da ação humana jamais podem ser governados por ela. Assim, conforme Arendt (2015), uma vez que os resultados da ação são imprevisíveis, irreversíveis e ilimitados, atribuir um significado puramente funcional ou utilitário para a capacidade humana de agir só poderia resultar na ausência de significado.

Pois um fim, assim que é atingido, deixa de ser um fim e perde sua capacidade de orientar e justificar a escolha de meios, de organizá-los e produzi-los. Passa a ser então um objeto entre objetos, ou seja, foi acrescentado ao enorme arsenal de coisas dadas do qual o homo faber seleciona livremente os meios de atingir seus fins. O significado, ao contrário, deve ser permanente e nada perde de seu caráter, quer ele seja alcançado 
ou, antes, encontrado pelo homem, quer o homem fracasse e o perca (ARENDT, 2015, p. 192).

Ainda que o agente tenha clareza de seus objetivos e de suas motivações ao agir, ele jamais pode ter certeza de que as consequências de seus atos e suas palavras atingirão um fim estabelecido de antemão. O caráter ilimitado da ação, isto é, sua extraordinária capacidade de estabelecer relações pode não apenas frustrar as intenções do agente, mas também produzir efeitos contrários ao seu intento inicial. A significação da ação humana é trágica porque, no pensamento arendtiano, o agente nunca pode prever os desdobramentos de seus atos e de suas palavras, e, à maneira de Édipo, torna-se absolutamente cego para o que pode acontecer ao término de sua ação. Assim, o significado da ação está oculto para o agente, enquanto estiver envolvido no ato ou emaranhado em suas consequências, e, por isso, os resultados de sua iniciativa somente se revelam para o contador da estória (storyteller). Não raro, segundo Arendt (2015, p. 238), os processos desencadeados pela ação somente podem aparecer “[...] quando todos os participantes já estão mortos". Para Arendt, ao contrário dos padrões de comportamento, é impossível prever a ação humana ou controlar seus resultados. Por isso, na qualidade de atores, os homens jamais podem fazer sua própria história ${ }^{17}$. Segundo Arendt (2015, p. 289):

Os homens sempre souberam que aquele que age nunca sabe completamente o que
está fazendo; que sempre vem a ser 'culpado' de consequências que jamais pretendeu
ou previu; que, por mais desastrosas e imprevistas que sejam as consequências do seu
ato, jamais poderá desfazê-lo; que o processo por ele iniciado jamais se consuma
inequivocadamente em um único ato ou evento, e que seu verdadeiro significado
jamais se desvela para o ator, mas somente à mirada retrospectiva do historiador, que
não age.

Ao agir, o agente cria condições para que seus atos e suas palavras possam ser lembrados e, portanto, que sua estória de vida possa ser narrada no grande livro de estórias (storybook) da humanidade (ARENDT, 2105). "Que toda vida individual entre o nascimento e a morte possa afinal ser narrada como uma estória com começo e fim é, de acordo com Arendt (2015, p. 228), a condição pré-política e pré-histórica da história [history], a grande estória sem começo nem

\footnotetext{
${ }^{17}$ A crítica ao historicismo é mais um dos temas no qual Arendt se opõe à filosofia política de Marx. Nesse ponto, a posição de Arendt é diametralmente oposta à de Marx (1978, p. 329), segundo a qual "Os homens fazem sua própria história, mas não a fazem como querem; não a fazem sob circunstâncias de sua escolha e sim sob aquelas com que se defrontam diretamente, legadas e transmitidas pelo passado". Para Arendt (2015), ao contrário, somente na qualidade de historiador, isto é, de contador das estórias podemos fazer nossa própria história, podemos reificar em palavras o que pensamos sobre os resultados decorrentes das ações humanas. É somente nesse sentido que, para Arendt, os homens fazem sua própria história. Como contadores de estórias, os seres humanos possuem a capacidade de contar estórias, de narrar e, assim, lembrar-se do que passou a existir inevitavelmente entre nós. Nesse sentido, a história pode ser lida, conforme Arendt (2015), como o grande livro de estórias (storybook) da humanidade.
} 
fim". Nesse sentido, a chegada de seres novos no mundo obsta qualquer tentativa de prever o fim da história. A ação é a única atividade humana que pode imortalizar a vida de seres mortais, pois as estórias que podem ser contadas e recontadas sobre os ditos e feitos de alguém trazem à tona o caráter memorável de uma vida (RICOEUR, 2013). É por isso que a revelação do quem requer a presença de um historiador que não age, de um observador exterior que pode encadear os resultados da ação sob a forma de uma narrativa. Somente assim a ação pode se tornar um produto tangível, uma imagem de pensamento reificada pela mirada retrospectiva do historiador, que não age ${ }^{18}$. Por isso, o agente é incapaz de atribuir o significado que mais lhe aprouver à sua própria iniciativa. Pode-se dizer, nesse sentido, que a ação deixa os rastros de um alguém no mundo que, mesmo depois de sua efêmera passagem pela Terra, podem ser lembrados, de modo a inspirar novas ações. "A ligação entre ação e estória (story) constitui um dos temas mais notáveis de todo o tratado sobre a condição humana” (RICOEUR, 1996, p. 24, tradução nossa). Pois, segundo o filósofo francês (1996, p. 24-25, tradução nossa):

Hannah Arendt não vai dizer que o desdobramento da vida constitui enquanto tal uma estória, nem mesmo que a revelação do 'quem' seja por ela mesma uma estória. É somente em conjunto que a revelação do 'quem' e a rede de relações humanas engendram um processo donde pode emergir a estória única de não importa qual novo recém chegado.

Assim, conforme a interpretação de Ricoeur (1996, p. 25, tradução nossa), essa ligação entre o agir e o narrar tenta dar conta da "[...] opacidade de toda estória de uma vida para seu próprio 'herói'". O agente está sempre emaranhado em uma teia de relações humanas (web of human relationships), e, por isso, o significado de seus atos e suas palavras para o mundo dependem das narrativas que são compostas pelo contador de estórias (storyteller). É a partir dessas narrativas que o herói da ação, na qualidade de leitor ou ouvinte, pode agora reconhecer a grandeza - ou a mediocridade - de seus atos e suas palavras. É a partir dessas narrativas que somos inseridos como personagens no enredo desse grande livro de estórias sem começo nem fim (ARENDT, 2015). Portanto, é devido à pluralidade de estórias que podem ser contadas sobre uma mesma ação que o agente jamais pode controlar o significado de seus atos e suas palavras para o mundo. Para Arendt (2015), os resultados da ação não podem ser reivindicados

\footnotetext{
${ }^{18}$ As considerações arendtianas acerca da história e do historiador não se restringem ao campo da historiografia, isto é, à ciência da história e ao ofício do historiador. Para Arendt, como observa André Duarte (2003, p. 79, destaque do autor), "o historiador é o narrador ou o juiz que procura o sentido implicado nas ações humanas em seus diversos episódios particulares encontrando nexos inesperados entre eles ao toma-los como fragmentos dotados de singularidade significativa à luz do presente [...]. Assim, a história pela qual Arendt se interessa é uma história fragmentada, composta de 'situações únicas, de feitos e eventos que interrompem o movimento circular da vida diária', uma história aberta ao extraordinário e que, portanto, não se desenrola placidamente e nem se reduz à imagem tradicional do fluxo contínuo do tempo, comportando o 'salto de tigre em direção ao passado' (Tese XIV) em nome das exigências revolucionárias do presente e do futuro”.
} 
pelo agente como o fabricante de coisas reivindica, de direito, os produtos da fabricação. Ao término da ação, não haverá nada de tangível para o qual o agente possa apontar como sendo de sua autoria. "Em outras palavras, as estórias, resultado da ação e do discurso, revelam um agente, mas esse agente não é autor nem produtor" (ARENDT, 2015, p. 228).

Se o significado das consequências desencadeadas pela ação só se desvela para o contador da estória, para o agente, o significado da ação repousa no próprio ato que revela quem ele é. A revelação do quem (disclosure of who) é, segundo Ricoeur (1996), o principal critério para distinguir a ação das demais categorias da vita activa. "Um primeiro acento recai sobre o ‘quem', isto é, o sujeito responsável” (RICOEUR, 1996, p. 23, tradução nossa). A capacidade humana de agir revela um ser único que, mediante atos e palavras, é capaz de responder aos dilemas e às vicissitudes do mundo, de aparecer por iniciativa própria e, junto aos outros, interromper ou continuar os processos nos quais sua vida individual está inserida, confirmando de maneira única seu aparecimento físico e original em um mundo humano e comum.

Ao agir, cada ser humano se revela como um ser único e distinto dos demais, ao iniciar algo novo no mundo, cada ser humano pode confirmar sua distinção única na presença de outros seres igualmente únicos e distintos. No entanto, isso não significa que a ação seja concebida por Arendt como uma capacidade que o indivíduo tem de iniciar algo novo no mundo. Para Ricoeur (1996), Arendt é muito aristotélica para se fechar em um individualismo que a fizesse esquecer do sentido originário da política como aquilo que se passa entre homens e mulheres (no plural!) que possuem o dom da linguagem. Por isso, segundo Ricoeur (1996), na revelação do quem, o principal critério para distinguir a ação das demais categorias da vita activa, um segundo acento recai sobre o termo "revelação", de modo que o quem só se revela à medida que o agente aparece por iniciativa própria e passa a ser visto e ouvido por outros em um espaço de aparência. “A ação, portanto, não apenas mantém a mais íntima relação com a parte pública do mundo comum a todos nós, mas é a única atividade que o constitui” (ARENDT, 2015, p. 245).

Por fim, gostaríamos de observar que para um ser novo que se depara com toda sorte de coisas estranhas e, aos poucos, vai se familiarizando com o mundo no qual foi inserido pelo nascimento, o processo educativo é um tempo oportuno para configurar sua identidade pessoal. Assim, do ponto de vista de um recém chegado ao mundo, a atividade da educação pode ser entendida, à luz da teoria narrativa de Ricoeur (1994), como o processo no qual sua identidade pessoal é configurada mediante o esforço de se situar no horizonte aberto pelas obras que pertencem a diferentes tradições culturais do passado. Essa configuração se dá através de suas interações e experiências com os outros e com o mundo; de suas identificações com os 
personagens das narrativas que compõem o enredo de nosso grande livro de estórias; de suas interpretações dos múltiplos sentidos dos objetos culturais que constituem nosso mundo comum (ARENDT, 2013; RICOEUR, 1983; 1994). É dessa maneira que, na configuração de sua identidade pessoal, um recém chegado no mundo pode se apropriar daquilo que antes lhe era estranho e, assim, compreender-se diante do mundo com o qual busca se familiarizar.

Pode-se dizer, nesse sentido, que o aspecto ético da educação se manifesta para aqueles que assumem a responsabilidade de apresentar o mundo aos mais novos na configuração do enredo e na escolha dos personagens, na seleção de e nas relações entre as ações e os discursos desses personagens que atuam no espetáculo do mundo. Ou seja, ao compor o enredo de uma narrativa, de uma estória sobre alguma coisa do mundo que possuímos em comum, a atividade da educação se revela não apenas como uma técnica, mas também como uma ética (MARROU, 1973). Visto que, de acordo com Paul Ricoeur (1994, p. 145, itálico do autor), uma narrativa nunca é neutra, as narrativas que contamos aos mais novos em processo de vir a ser podem ser consideradas como “[...] o primeiro laboratório do juizo moral”. Desse modo, ao apresentar o mundo aos mais novos, a educação possibilita aos recém chegados o exercício de nossa capacidade de julgar, de avaliar e hierarquizar o que é belo e o que é feio, o que é justo e o que é injusto etc. E, nesse processo de escolher quais obras são dignas de permanecer no mundo e decidir como elas serão apresentadas aos mais novos, isto é, como será composto o enredo dessas narrativas que serão contadas aos recém chegados, à medida que, referindo-se ao mundo, o educador dirige suas palavras aos educandos, ele revela também quem ele é.

Para aqueles que devem assumir a tarefa de renovar nosso mundo comum, é preciso se familiarizar com as obras e os monumentos do passado (ARENDT, 2013), estabelecer laços simbólicos com as heranças culturais do passado (RICOEUR, 1975). Se ao longo do processo educativo, os mais novos se identificam com os personagens, com suas ações e seus discursos, que compõem o enredo das narrativas que lhes foram apresentadas pelos mais velhos, pode-se dizer que, tanto para o educador quanto para o educando, a atividade da educação consiste no ato de configurar uma identidade pessoal. Em La educación como acontecimento ético, Fernando Bárcena e Joan-Carles Mèlich (2000, p. 113, itálico do autor, tradução nossa) afirmam, com base no pensamento de Paul Ricoeur, que:

O protagonista da ação educativa, seja mestre ou discípulo, configura sua identidade (o relato de sua existência) narrativamente a partir de outros relatos que lhe foram contados ou que foram lidos por ele. Para responder à pergunta ‘quem és' é necessário narrar a história de uma vida. Mas o novo relato se faz a partir dos outros relatos que lemos ou que nos foram contados. A ação educativa configura a identidade pessoal inventando uma história de ficção que pode, paradoxalmente, ser real, porque a realidade se configura imaginativamente. 
Pode-se afirmar que, no processo educativo, a configuração de uma identidade pessoal se dá narrativamente não apenas por sua estória singular de vida, mas por intermédio de outras estórias, outros relatos a partir dos quais o sujeito da educação busca responder à pergunta que se faz a todo recém chegado: quem és? Nesse sentido, antes de revelar quem ele é para o mundo, um ser humano novo e em processo de vir a ser configura sua identidade pessoal à medida que se familiariza com as obras e os monumentos do passado. Ou seja, a constituição de um alguém ocorre na relação com o mundo e com os outros e a partir dessa experiência o sujeito da educação vai configurando sua identidade pessoal, compondo sua própria estória de vida. Assim, a identidade do quem é construída a partir das estórias que ele pode contar e recontar sobre si mesmo e o mundo. Nesse sentido, pode-se dizer que, para o sujeito da educação, constituir-se como uma pessoa é construir-se narrativamente como um personagem que se enlaça, no enredo de sua estória de vida, com outras estórias, outros relatos que lhe vão sendo narrados de diferentes maneiras pelos mais velhos. Segundo Ricoeur (2014, p. 155, itálico do autor):

A pessoa, entendida como personagem da narrativa, não é uma entidade distinta de
suas 'experiências'. Ao contrário: ela compartilha o regime da identidade da
personagem, que pode ser chamada de sua identidade narrativa, construindo a
identidade da história narrada. É a identidade da história que faz a identidade da
personagem.

A atividade da educação pode ser lida, nesse sentido, como uma modalidade de narração sobre as coisas mundanas que possuímos em comum; e o educador, como um contador de estórias que, ao apresentar o mundo para os mais novos, fornece os relatos a partir dos quais o sujeito da educação pode configurar narrativamente seu próprio relato de si, isto é, sua identidade pessoal. "Narrar é dizer quem fez o quê, por quê e como, estendendo no tempo a conexão entre esses pontos de vista" (RICOEUR, 2014, p. 153). Dessa maneira, o aspecto ético da educação se manifesta no modo como o educador e o educando configuram e refiguram seus personagens e enredos, suas narrativas sobre si mesmos e sobre as coisas do mundo.

Ao dirigir a palavra aos mais novos para dizer o que é o mundo, ao se relacionar com um outro a fim de falar sobre o que se passa ao nosso redor e de como isso nos afeta, o educador não pode deixar de dizer quem ele é e de que lugar o mundo é visto por ele. Na relação educativa que se dá no encontro entre os mais velhos e os mais novos, entre aqueles que têm a responsabilidade de erigir e conservar um mundo comum e aqueles cuja tarefa é a de renovalo, não há outra maneira de responder pelas obras e monumentos do passado e, ao mesmo tempo, de imaginar um mundo que ainda não é senão em nome próprio. É sempre um alguém 
que apresenta o mundo para os mais novos, que escolhe o que mostrar e o caminho a percorrer por entre as obras e os monumentos do passado, que julga quais estórias desse grande livro sem começo e sem fim é preciso narrar a esses seres novos e em vir a ser cuja estória de vida está só começando... 


\section{A INVENÇÃO DA $S K H O L \bar{E}$ : SOBRE A ORIGEM E A POTÊNCIA DA ESCOLA}

\begin{abstract}
Normalmente a criança é introduzida ao mundo pela primeira vez através da escola. No entanto, a escola não é de modo algum o mundo e não deve fingir sê-lo; ela é, em vez disso, a instituição que interpomos entre o domínio privado do lar e o mundo com o fito de fazer com que seja possível a transição, de alguma forma, da família para o mundo.
\end{abstract}

Hannah Arendt, Crise na educação

A escola não é uma função ou um lugar definido por uma finalidade social exterior. Ela é, antes, uma forma simbólica, uma norma de separação de espaços, tempos e ocupações sociais. Escola não quer dizer fundamentalmente aprendizagem, mas tempo livre (loisir).

Jacques Rancière, Escola, produção, igualdade

No ensaio Le symbole donne à penser, publicado em 1959 na revista Esprit, Paul Ricoeur inicia sua meditação sobre os símbolos com uma breve observação acerca desse título, que, segundo o autor, o encantava por duas razões: a primeira era que o símbolo dá e, portanto, não se pode atribuir um sentido para o símbolo porque é ele que dá o sentido; e a segunda era que, a partir dessa doação, o pensamento interpreta o sentido que lhe é dado - e talvez seja esse o dom do pensamento. É preciso, portanto, que o pensamento se mova incessantemente no domínio do simbólico, interprete o sentido múltiplo dos símbolos (dos signos, dos ritos etc.). “A sentença [o símbolo dá a pensar] sugere então, ao mesmo tempo, que tudo já está dito em enigma e, portanto, que é preciso sempre começar e recomeçar na dimensão do pensar" (RICOEUR, 1959, p. 60, tradução nossa).

Para Ricoeur (1969), o símbolo e a interpretação são conceitos correlativos. O símbolo é uma estrutura de significação na qual um sentido designa por acréscimo outro sentido; e a interpretação, um desdobramento dos níveis de significação que estão implicados no sentido que nos é dado (RICOEUR, 1969). Se considerássemos o caráter simbólico da escola, poderíamos dizer, de acordo com o pensamento de Ricoeur, que ela é uma estrutura de significação na qual o sentido que nos é dado pode manifestar, por meio de diferentes interpretações, uma pluralidade de sentidos. Assim, diríamos que a escola nos dá a pensar porque seu sentido é múltiplo e que interpretar os potenciais sentidos da escola consiste em desdobrar os níveis de significação implicados no sentido que nos é dado.

Ocorre que, em sua autobiografia intelectual, Ricoeur (1995b) reconhece os limites de sua reflexão sobre os símbolos como decifração por acréscimo de sentido e declara que sua 
hermenêutica se apoiava em uma noção amplificante de interpretação. Por vezes, segundo Ricoeur (1995b, p. 35, tradução nossa), essa noção era designada por ele mesmo como recuperadora, pois "[...] tratava-se de recuperar um sentido que estava ali e dissimulado por outro". Ricoeur (1995b) reinterpreta essa noção com a mudança de paradigmas filosóficos franceses ocorrida ao longo dos anos de 1970. Em outras palavras, após sua travessia pela paisagem movediça dos anos de 1970 na França (GAGNEBIN, 2006), Ricoeur passou a adotar uma noção redutora de interpretação. Ao invés de desdobrar os níveis de significação implicados no sentido que é dado pelo símbolo, o intérprete reconfigura, no ato de ler, o mundo do texto e se situa no horizonte aberto pela obra. Ou seja, com base em uma noção redutora de interpretação, o círculo hermenêutico entre o símbolo e o intérprete dá lugar ao confronto entre o mundo do texto e o mundo do leitor. Nesse processo hermenêutico, como observa Jeanne Marie Gagnebin (2006), o sujeito da interpretação é desapropriado de si em favor da obra interpretada. Em sua ascese diante da alteridade da obra, o intérprete (o leitor) se desaloja de sua identidade e, com isso, abre-se para ele novas possibilidades de habitar o mundo (GAGNEBIN, 2006).

A tarefa dessa hermenêutica fundada em uma noção redutora de interpretação é apresentada por Ricoeur em Tempo e Narrativa, obra publicada em três volumes na primeira metade dos anos de 1980. De acordo com Ricoeur (1994, p. 86, tradução modificada), ela consiste em "[...] reconstruir o conjunto das operações pelas quais uma obra eleva-se do fundo opaco do viver, do agir e do sofrer, para ser dada por um autor a um leitor que a recebe e assim muda seu agir"19. E, aqui, o intérprete não estaria mais preocupado em decifrar ou recuperar um sentido para aquele outro que é dado pelo símbolo. Mediante a experiência da leitura, a preocupação do intérprete se volta para a refiguração do mundo configurado pelo autor de um texto. Nesse sentido, pode-se dizer que não somente $o$ símbolo, mas também o texto, dá $a$ pensar. E através dessa doação, o leitor busca compreender o mundo configurado pelo autor de um texto. Ao se situar no mundo do texto, no horizonte aberto pela obra, o leitor é capaz de compreender-se diante do texto ${ }^{20}$ (RICOEUR, 1986).

\footnotetext{
${ }^{19}$ Provavelmente por um erro de digitação, o termo auteur foi traduzido, na edição brasileira, por ator.

${ }^{20}$ A esse respeito ver o ensaio de Paul Ricoeur (1986), La fonction hermenéutique de la distanciation, publicado na obra Du texte a l'action. Essa função hermenêutica do afastamento, da distância que o intérprete toma da coisa interpretada e que permite interpretar a obra e a si mesmo, pode ser vista também na noção arendtiana de compreensão. Para Arendt, a tarefa (interminável) de compreender os acontecimentos políticos e históricos sem precedentes consistia em buscar uma conciliação com o passado, uma vez que o horror do fenômeno totalitário jamais poderia ser explicado. A compreensão é, para Arendt (2008), o significado que atribuímos ao que fazemos e ao que sofremos no próprio processo de viver - seria interessante comparar a categoria de ação na análise da vita activa em Hannah Arendt e o conceito de práxis na teoria narrativa de Paul Ricoeur. Em Compreensão e política, Arendt (2008) afirma que a compreensão não pode ter consequências no combate ao totalitarismo. Porém, sem compreender contra $o$ que se luta, na ausência do significado político da luta contra a dominação total, esse
} 
Para os nossos propósitos, é importante destacar que, para Ricoeur (1994), a tarefa hermenêutica do leitor consiste em refigurar o mundo configurado pelo autor de um texto. E essa refiguração se desdobra tanto na relação do leitor consigo mesmo quanto no campo ético da existência humana (RICOEUR, 2014). É nesse sentido que, através da leitura, o leitor modifica seu agir (RICOEUR, 1994). Para Ricoeur (1986), há mais do que uma convergência fortuita entre texto e ação. Se o leitor é chamado a compreender-se diante do texto, como mostra Ricoeur (1986) no ensaio Expliquer et compreendre, publicado em Du texte a l'action, é porque ele não está fechado em si mesmo, mas aberto no mundo que ele reconfigura e refaz pela leitura. Essa abertura é, pois, o que permite ao leitor não apenas interpretar o mundo, mas também agir sobre ele, isto é, operar uma mudança no mundo, intervir no curso das coisas (RICOEUR, 1986). Desse modo, Ricoeur expande a possibilidade desse esforço interpretativo para a própria ação humana, já que ela também pode ser lida e interpretada como um texto. "Para o agente, interpretar o texto da ação é autointerpretar-se" (RICOEUR, 2014, p. 196). Se considerássemos a escola como um texto que pode ser lido e interpretado, poderíamos dizer, conforme as análises de Ricoeur, que ela configura um mundo no qual, como leitores ou, mais precisamente, como professores situados no horizonte aberto pela escola, podemos narrativamente refigurar nosso mundo e agir sobre ele. Diríamos então que nos tornamos professoras e professores na medida em que passamos a habitar o conjunto de referências configurado pelo mundo da escola e passamos a intervir nele.

Propomos nesse capítulo interpretar a escola a partir da experiência grega da skhole, uma interpretação do que a invenção da skholē nos dá a pensar sobre a potência da escola. Nesse sentido, como é possível interpretar - talvez de maneira amplificante - o fenômeno originário da escola? De que modo se pode desdobrar o sentido que nos é dado por essa palavra grega, $s k h o l e \bar{e}$, que ressoa toda vez que pronunciamos a palavra escola? Acaso a compreensão dessa experiência que subjaz à invenção da skholē pode ser lida como uma abertura para compreender o que fazemos e o que sofremos na escola? Nosso propósito aqui será o de mostrar como a origem e a potência da escola podem ser interpretadas com base na experiência que subjaz à invenção da skhole; ; e de como a novidade dessa invenção que eclodiu no seio da pólis grega pode ser pensada, em nossos dias, como uma abertura no campo dos possíveis da escola. A partir do pensamento de Hannah Arendt, como veremos, poderíamos ainda nos perguntar de

combate se reduziria à mera luta pela sobrevivência, "Na medida em que os movimentos totalitários surgiram no mundo não totalitário (cristalizando elementos existentes nesse mundo, visto que os governos totalitários não caíram do céu), o processo de compreensão também é, com toda evidência e talvez em primeiro lugar, um processo de autocompreensão” (ARENDT, 2008, p. 333, itálico nosso). 
que maneira a novidade dessa invenção, a skholē, pode ser lembrada e ouvida mais uma vez como algo novo. Para isso, será preciso tomar distância da escola, do lugar onde aparecemos e somos vistos como professores, e nos aproximar da skholē a fim de ouvir o que ela tem a nos dizer. Talvez, dessa maneira, sendo chamados a nos compreender diante do mundo configurado pela escola, poderíamos refigurar o conjunto de referências e operações que põe em movimento a lógica da escola. E talvez, situados no horizonte aberto pela invenção da skhole, sejamos capazes de mudar o nosso modo de agir e de pensar no seio da escola.

\subsection{O fio rompido da tradição e a ameaça do esquecimento}

No Prefácio de Origens do Totalitarismo, Hannah Arendt (2012, p. 12) declara que sua tentativa de compreender o fenômeno totalitário consistia em "[...] encarar a realidade sem preconceitos e com atenção, e resistir a ela - qualquer que seja". O confronto com a realidade inédita dos regimes totalitários exigiu de Arendt uma nova maneira de ouvir o passado a fim de tentar compreender o que havia acontecido. Para Arendt, diante da concretude e do horror dos campos de concentração, nossas categorias de pensamento político e nossos critérios de juízo moral entraram em colapso. Após o fenômeno totalitário, seria inútil buscar em nossa tradição de filosofia política aqueles eventos com os quais poderíamos estabelecer qualquer comparação com o totalitarismo. Não havia qualquer chance de encontrar, nos acontecimentos políticos do passado, elementos que pudessem nos fornecer alguma resposta para aquelas perguntas com as quais, segundo Arendt (2012, p. 415, itálico da autora), a geração do pós guerra estaria condenada a conviver: "O que havia acontecido? Por que havia acontecido? Como pôde ter acontecido?". De acordo com a análise arendtiana (2012), o totalitarismo é um fenômeno sem

precedentes e, por isso, qualquer tentativa de compreendê-lo a partir de generalidades e analogias com os acontecimentos políticos do passado estaria, de antemão, fadada ao fracasso.

A tarefa de compreender o fenômeno totalitário, segundo Arendt (2012, p. 12), jamais pode se esquivar de “[...] o impacto da realidade e o choque da experiência”. Em Compreensão e política, Arendt (2008, p. 332) afirma que:

A originalidade do totalitarismo é atroz, não porque surgiu alguma nova 'ideia' no mundo, mas porque suas ações constituem uma ruptura com todas as nossas tradições; elas demoliram indiscutivelmente nossas categorias de pensamento político e nossos critérios de julgamento moral.

Para os nossos intuitos, é importante observar que, de acordo com Arendt (2008), a realidade do fenômeno totalitário, a atrocidade das ações levadas a cabo pelos sistemas 
totalitários, é vista como um dos sintomas mais seguros de uma ruptura com nossa tradição de pensamento político. "Em outras palavras, o próprio acontecimento, o fenômeno que tentamos - e devemos tentar - compreender, nos privou de nossos instrumentos tradicionais de compreensão" (ARENDT, 2008, p. 332). Porém, para Arendt, isso não significava que, diante da impossibilidade de explicar o que havia acontecido, fosse impossível compreender o fenômeno totalitário, tão pouco que a única saída para essa perplexidade fosse abandonar o passado. Ao contrário, para Arendt, sem a possibilidade de nos movermos por entre os vastos domínios do passado, seria impossível compreender o que quer que seja.

Ora, em face de uma ruptura com todas as nossas tradições, de que maneira Arendt buscou lidar com os acontecimentos do passado a fim de compreender o fenômeno totalitário? Para Arendt (2008b), o passado abriga algo de rico e estranho que, com a ruptura da tradição, já não se apresenta como um bloco sólido, mas antes em fragmentos. É preciso, portanto, buscar esses fragmentos nos vastos domínios do passado e interpretá-los à luz do presente, pois sem a autoridade que a tradição conferia ao passado, seus fragmentos correm o risco de desaparecer. No ensaio Walter Benjamin (1892-1940) ${ }^{21}$, Arendt (2008b, p. 222) se refere metaforicamente ao filósofo alemão "como um pescador de pérolas que desce ao fundo do mar, não para escaválo e trazê-lo à luz, mas para extrair o rico e o estranho, as pérolas e o coral das profundezas, e trazê-los à superfície [...]”. Nesse sentido, conforme Arendt (2008b), para compreender um fenômeno sem precedentes que ocorreu no passado, é preciso sondar as profundezas de seus vastos domínios, estar convicto de que aquilo que outrora era vivo sofrerá um processo de cristalização e que, mesmo emergindo das águas profundas do passado, esses fragmentos cristalizados jamais poderão ser trazidos de volta ao mundo dos vivos. Pode-se dizer que esse gesto de recolher algo de rico e estranho que se cristalizou e está sedimentado nas águas

\footnotetext{
${ }^{21}$ Esse texto foi publicado originalmente em 1968 como uma introdução à coletânea de ensaios e reflexões de Walter Benjamin, Illuminations, organizada por Hannah Arendt a fim de divulgar o pensamento do filósofo alemão ao público norte-americano. No mesmo ano, esse ensaio foi publicado na obra Homens em tempos sombrios. Para Arendt (2008b), o fio que tornava possível reunir estórias de vida de homens e mulheres que viveram em épocas distintas em uma mesma coletânea de ensaios e artigos é o fato de que eram contemporâneos. Ou seja, todos viveram em períodos nos quais a luz do domínio público havia se tornado trêmula e fraca e, mesmo assim, segundo Arendt (2008b, p. 09), “[...] mesmo no tempo mais sombrio temos o direito de esperar alguma iluminação, e que tal iluminação pode bem provir, menos das teorias e conceitos, e mais da luz incerta, bruxuleante e frequentemente fraca que alguns homens e mulheres, nas suas vidas e obras, farão brilhar em quase todas as circunstâncias e irradiarão pelo tempo que lhes foi dado na Terra [...]". Poderíamos dizer que esse fio com o qual Arendt articula o passado e torna contemporâneos homens e mulheres que viveram em épocas distintas foi urdido por Benjamin em suas teses "Sobre o conceito de história" - cuja publicação póstuma realizada pelo Instituto de Pesquisa Social de Frankfurt, em 1942, deve-se a uma cópia que Benjamin confiou a Arendt e a qual foi entregue para Adorno que já se encontrava exilado nos EUA (LÖWY, 2005). Na tese VI, Benjamin afirma que "Articular o passado historicamente não significa conhecê-lo 'tal como ele propriamente foi'. Significa apoderar-se de uma lembrança tal como ela lampeja num instante de perigo" (LÖWY, 2005, p. 65, tradução de Jeanne Marie Gagnebin e Marcos Müller).
} 
profundas do passado é comum tanto em Walter Benjamin quanto em Hannah Arendt. Ao serem trazidos à superfície, esses fragmentos não podem ser mais o que foram no passado, pois, como nos versos de Shakespeare citados por Arendt (2008b, p. 208), sofreram "[...] uma transformação marinha [...]" e, tal como as pérolas e o coral, cristalizaram-se em algo de rico e estranho.

Por isso é importante destacar aqui a distinção arendtiana entre passado e tradição. Para Arendt, é preciso considerar a diferença entre, de um lado, os fenômenos do passado que, vistos como fragmentos cristalizados, podem ser interpretados à luz do presente e manifestar algo de rico e estranho e, de outro, a autoridade do passado cuja imagem desses fenômenos a tradição nos apresentava de maneira homogênea e sob um aspecto predeterminado.

\footnotetext{
Assim, a perda inegável da tradição no mundo moderno não acarreta absolutamente uma perda do passado, pois a tradição e o passado não são a mesma coisa, como os que acreditam na tradição, por um lado, e os que acreditam no progresso, de outro [...]. Com a perda da tradição, perdemos o fio que nos guiava pelos vastos domínios do passado; esse fio, porém, foi também a cadeia que aguilhoou cada sucessiva geração a um aspecto predeterminado do passado. Poderia ocorrer que somente agora o passado se abrisse a nós com inesperada novidade e nos dissesse coisas que ninguém teve ainda ouvidos para ouvir (ARENDT, 2013, p. 130).
}

Com a ruptura desse fio que nos guiava de geração em geração, o passado pode se abrir para nós e se revelar sob novos aspectos. Para os nossos propósitos, gostaríamos de sublinhar a metáfora do fio que Arendt emprega frequentemente para sustentar a tese da perda da tradição. A imagem de um fio que nos guiava pelos vastos domínios do passado e que, ao mesmo tempo, mantinha-nos presos a uma imagem cristalizada do passado nos faz lembrar de outra imagem: a do novelo de linha que, no mito grego, Ariadne dá a Teseu a fim de guiá-lo para fora do labirinto de Minotauro. A fim de enfrentar a criatura monstruosa que vivia encerrada em um labirinto construído para que ninguém pudesse escapar, Teseu recebe um presente de Ariadne: um novelo de linha. E à medida que, no encalço de Minotauro, o herói avançava por entre as encruzilhadas do labirinto, Teseu desenrolava o novelo e, com um fio estendido por onde havia passado, sinalizava o caminho de volta. Graças a esse expediente, Teseu conseguiu cumprir seu desígnio e escapar do labirinto (KURY, 2001).

Mas será que, após ter abatido Minotauro, Teseu teria conseguido escapar do labirinto sem esse fio? Ou se esse fio tivesse se rompido, qual teria sido o destino do herói ateniense? Sem esse fio, em qual coisa ele poderia se fiar? Poderíamos imaginar que se, no mito grego, esse fio se rompesse, Teseu permaneceria perdido para sempre no labirinto - ou, pelo menos, até que um deus ou uma deusa o salvasse de lá. Mas a contrapartida desse expediente é que, guiado pelo fio de Ariadne, o caminho de volta se apresentava para Teseu como um único 
caminho, mantendo-o preso a um aspecto predeterminado do labirinto. Assim, na medida em que Teseu caminhava em direção ao monstro, um caminho se cristalizava para ele como o único caminho por onde se poderia escapar. Talvez existissem caminhos mais curtos e menos perigosos, caminhos que não puderam se abrir para Teseu e que somente poderia se abrir em um caminhar errante. Se, no mito grego, o fio de Ariadne indica para o herói a única saída possível a fim de escapar do labirinto, no pensamento arendtiano, a metáfora do fio rompido sugere que, se quisermos encontrar uma saída para os problemas labirínticos de nosso mundo, é preciso errar por entre suas encruzilhadas. E talvez um dos exemplos mais contundentes dessa errância do pensamento seja a própria maneira como Arendt buscou compreender a essência do totalitarismo.

Através dessas considerações, pode-se afirmar que, em face do colapso de nossa tradição de pensamento político, Arendt buscou de uma nova maneira pensar politicamente os fragmentos cristalizados do passado. Pode-se dizer, nesse sentido, que a potência do pensamento arendtiano consiste em trazer à luz do presente os fenômenos que ficaram esquecidos nas dobras de nossa tradição de pensamento político. Contudo, segundo Arendt (2013, p. 131):

\footnotetext{
Não se pode negar que, sem uma tradição firmemente ancorada - e a perda dessa firmeza ocorreu muitos séculos atrás -, toda a dimensão do passado foi também posta em perigo. Estamos ameaçados de esquecimento, e um tal olvido - pondo inteiramente de parte os conteúdos que se poderiam perder - significaria que, humanamente falando, nos teríamos privado de uma dimensão, a dimensão de profundidade na existência humana. Pois memória e profundidade são o mesmo, ou antes, a profundidade não pode ser alcançada pelo homem a não ser pela recordação.
}

Se o fio rompido da tradição nos abre a possibilidade de uma autêntica experiência para o pensamento, essa ruptura põe em risco, ao mesmo tempo, a memória dos acontecimentos que naufragaram nas águas profundas do passado. Isso significa que essa ameaça de esquecimento, a qual pode nos privar de nossa dimensão de profundidade, aponta para a possibilidade de que os fragmentos cristalizados do passado desapareçam. Privados de nossa dimensão de profundidade, é como se o passado fosse despojado de sua dignidade, fosse reduzido àquilo que não existe mais ou, ainda pior, pudesse ser concebido como algo longínquo e suscetível de ser trazido de volta ao mundo dos vivos. Essa é a atitude em relação ao passado que, segundo Arendt (2008), caracterizava os bons e velhos clichês do liberalismo e do conservadorismo em sua vã e nociva tentativa de compreender um fenômeno sem precedentes como o totalitarismo. A nocividade dessa atitude não se restringe à sua intrínseca falta de sentido. Ela implica no fracasso da compreensão, da tarefa de compreender o significado político da luta contra o 
totalitarismo no plano intelectual (ARENDT, 2008). Ademais, segundo Arendt (2008, p. 306, itálico nosso):

Torna-se também um obstáculo a qualquer tentativa séria de formar novos conceitos em filosofia política e de conceber novas soluções para nossas dificuldades políticas, porque artificialmente confere uma aparência de vida a tudo que, bem ou mal, já está morto.

Convém lembrar, aqui, da interpretação arendtiana acerca da parábola de Kafka - cujo significado, segundo Arendt (2013, 2000), limita-se à atividade do pensamento. Nessa parábola, a personagem chamada Ele se encontra em um campo de batalha entre dois adversários, os quais estão armados com uma espécie de lança. O primeiro está posicionado atrás de Ele e, com a ponta de sua arma, empurra-o para frente; e o outro, situado à sua frente, não apenas impede que Ele avance, mas também o faz recuar. Ao se ver encurralado entre seus dois adversários, Ele sonha em saltar para fora do campo de batalha, passando assim a arbitrar a luta entre os dois combatentes. Na interpretação arendtiana, se Ele usasse, ao mesmo tempo, essas duas forças para se mover nesse campo de batalha (e não para fugir do combate!), a personagem de Kafka teria ao menos uma chance de encarar com atenção essa realidade e resistir a ela. Para Arendt, essa parábola podia ser lida como uma metáfora da própria atividade do pensamento. A fim de obter alguma chance contra essas forças que o encurralam no campo de batalha, Ele - ou, se preferirmos, o eu pensante em termos arendtianos -, precisa se mover por entre elas, isto é, mover-se entre o passado e o futuro. Poderíamos dizer que, para Arendt, a experiência do pensamento depende dessas duas forças que agem sobre nosso eu pensante. Isso significa que, privados de nossa dimensão de profundidade, nossas atividades mentais correriam o risco de se limitar ao futuro de um presente sem passado. Desse modo, sem aqueles adversários que aguilhoavam Ele pela frente, do futuro, e por detrás, da origem, conforme Arendt (2013), não haveria nenhuma chance de resistir ao combate.

Pode-se afirmar, nesse sentido, que a perda da memória do passado aponta para a impossibilidade de uma autêntica experiência do pensamento. Contudo, esse esquecimento, essa incapacidade de recordar e interpretar os fragmentos cristalizados do passado, pode também acarretar graves consequências do ponto de vista moral. Ao se tornar incapaz de exercer plenamente a capacidade de pensar, isto é, de representar, por meio da imaginação, os acontecimentos do passado e estabelecer um diálogo silencioso consigo mesmo acerca dessas imagens de pensamento, para Arendt, um ser humano corre o risco de se despojar também de sua capacidade de julgar, de fazer distinções e tomar decisões entre o que quer que seja. Ao se tornar incapaz de estar a só consigo mesmo (solitude), o eu pensante se vê abandonado por si 
mesmo; e, em solidão (loneliness), pode se esquecer tanto dos fragmentos cristalizados do passado quanto de seus próprios atos e suas próprias palavras. É por isso que, para Arendt, a ameaça de esquecimento suscita um problema moral. E, na medida em que esse problema está intimamente relacionado com a questão do $\mathrm{mal}^{22}$, a incapacidade de lembrar pode resultar em consequências catastróficas. Em Algumas questões de filosofia moral, Arendt (2004, p. 159160) afirma que "os maiores malfeitores são aqueles que não se lembram porque nunca pensam na questão e, sem lembrança, nada consegue detê-los".

Nesse sentido, é oportuno mostrar de que maneira, para Arendt, o despojamento de nossa plena capacidade de pensar (thoughtfulness), isto é, de lembrar tanto dos fragmentos cristalizados do passado quanto dos atos que cometemos e das palavras que pronunciamos a fim de refletir sobre eles, põe em perigo também nossa capacidade de julgar. Na medida em que a recusa ao exercício de nossa capacidade de pensar obsta nossa capacidade de lembrar e de refletir sobre os acontecimentos do passado, em situações de emergência, esse obstáculo pode nos privar também do exercício de nossa capacidade de julgar. É como se, ao ser abandonado por si mesmo, um ser humano se tornasse incapaz de questionar o vivido, e, em solidão, se tornasse indiferente a toda sorte de questões políticas e morais que podem emergir em tempos sombrios. Para Arendt (2004), o problema é que, quando as leis e as condutas morais se tornam descartáveis, elas podem ser substituídas por outras como se, tanto para a legalidade quanto para a moralidade, não houvesse prejuízo algum. E as consequências desse fenômeno podem ser desastrosas não apenas para aqueles que, ao serem abandonados por si mesmos e se tornarem incapazes de pensar e de ajuizar, podem perpetrar o mal, mas também - e sobretudo - para os que habitam o mundo ao seu redor. Diante da instabilidade e da mudança repentina de leis e condutas morais que caracterizam um mundo totalitário, o que era intolerável e inadmissível pode se tornar, de um dia para o outro, tolerado e admitido por aqueles que foram abandonados por si mesmos e se encontram privados do exercício de nossa capacidade de pensar e de julgar.

Essa ameaça de esquecimento que pode nos despojar de nossa dimensão de profundidade aponta para o risco de nosso desenraizamento do mundo, para o perigo de que aquilo que fazemos e que sofremos não tenha sequer um sentido para nós mesmo. E, nesse caso, o abandono de si mesmo põe em perigo não apenas aquele que é incapaz de ou se recusa a exercitar sua capacidade de julgar e de distinguir, mas se estende a tudo e a todos que, de algum modo, compartilham o mundo com ele. Há uma cena emblemática dessa ameaça de

${ }^{22}$ A esse respeito ver Giacoia (2011). 
esquecimento implicada nessa incapacidade ou recusa no filme Parasita (2019), dirigido pelo cineasta sul coreano, Bong Joon Ho. Em uma noite chuvosa, a ex-governanta aproveita que a família Park havia saído de viagem para retornar à mansão e revelar um segredo para sua substituta, Choong Sook. Seu marido estava, há anos, escondido em um búnquer dentro da mansão onde ela trabalhava; e, desde sua saída, há alguns dias, ele permanecia sem água e sem comida. Perplexa, Choong Sook acompanha a ex-governanta até o local onde seu marido estava escondido. Diante daquele encontro insólito, Choong Sook insiste que a ex-governanta deixasse imediatamente a casa da família Park. Porém, em uma reviravolta, a antiga governanta descobre a farsa da família Kim, descobre que todos os novos empregados da família Park, aparentemente desconhecidos, pertenciam à família de Choong Sook. Diante disso, a exgovernanta ameaça revelar aquela farsa aos membros da família Park assim que eles retornassem à mansão. Mas em uma nova reviravolta, a fim de evitar que tudo viesse à tona, a família de Choong Sook trava uma luta contra a ex-governanta e seu marido, os quais, depois de bastante feridos, são amarrados e amordaçados dentro do búnquer. O marido de Choong Sook, Sr. Kim, e seus filhos conseguem escapar da mansão a tempo de não serem descobertos pelos membros da família Park. E, sob o temporal que despencava naquela noite, eles retornam para casa que moravam, no subúrbio da cidade. A caminho de casa, Ki Woo, um dos filhos de Choong Sook, pergunta a seu pai qual era o plano, o que fariam com a ex-governanta e seu marido que ficaram presos no esconderijo subterrâneo da mansão. Em resposta, Sr. Kim se volta para seus filhos e, entreolhando-se, diz que somente eles sabiam o que tinha acontecido e que se esquecessem de tudo, ninguém jamais saberá o que aconteceu. Essa ameaça de esquecimento, essa incapacidade ou recusa de lembrar e de refletir, de ajuizar acerca de nossos atos e nossas palavras, pode deixar o caminho aberto para a perpetração do mal. Segundo Arendt (2004, p. 158, tradução modificada):

\footnotetext{
O pensamento como uma atividade pode surgir a partir de qualquer ocorrência; está presente quando eu, depois de observar um incidente na rua ou me ver implicada em alguma ocorrência, começo então a considerar o que aconteceu, contando o fato a mim mesma como uma espécie de estória (story), preparando-a, dessa maneira, para a subsequente comunicação aos outros, e assim por diante. Certamente que o mesmo é ainda mais verdadeiro se o tópico de minha consideração for algo que eu mesma cometi.
}

Para os nossos propósitos, é importante observar que a privação de nossa dimensão de profundidade não significa apenas a incapacidade de lembrar dos fenômenos originários e interpretar os fragmentos cristalizados do passado. Ela tem a ver, igualmente, com o fato de que, despojados da lembrança e da reflexão, perdemos a nossa capacidade de aparecer para nós 
mesmos como um personagem, como um outro de si mesmo (RICOUER, 2014). O problema é que, para Arendt, a constituição de um alguém, e não apenas o aparecimento de um indivíduo da espécie humana, depende do exercício de nossas atividades mentais do pensamento e do juízo; depende, em outras palavras, de nossa capacidade de aparecer para nós mesmos como um personagem no enredo de nossa estória singular de vida, que começa com o nosso nascimento e termina com a nossa morte. Sem esse exercício de lembrar e refletir sobre nossos atos e nossas palavras, estamos ameaçados pela solidão, pelo abandono de si.

Ao contrário de um alguém, que é capaz de lembrar de suas ações e, por meio da reflexão, atribuir um significado para suas lembranças, um ninguém é despojado de sua relação consigo mesmo. Ao ser amparado por uma organização (seja, por exemplo, como membro de uma facção criminosa ou de um governo autoritário inspirados por princípios fascistas contrários à liberdade e à igualdade), um ninguém se subordina inteiramente ao seu superior, torna-se capaz de cumprir quaisquer ordens, fazer qualquer coisa que tenha sido definida hierarquicamente pela burocracia da organização que ele faz parte. É porque se recusa a assumir a responsabilidade por seus atos e suas palavras que um ninguém é capaz de fazer qualquer coisa, é incapaz de dizer não. Pode-se dizer, conforme Arendt (2012), que, para um ninguém, tudo é permitido desde que ele não responda por isso. É nesse sentido que, para Arendt, o diálogo silencioso consigo mesmo pode impedir catástrofes em tempos sombrios, pois, nesses momentos em que à luz do espaço público se encontra trêmula e fraca, o simples fato de dizer não e se recusar a cumprir ordens se torna uma espécie de ação (ARENDT, 2003, 2008b).

Ocorre que, mesmo em tempos sombrios, essa incapacidade ou recusa de refletir sobre os atos cometidos e as palavras pronunciadas não necessariamente transforma um ninguém em uma criatura diabólica ou monstruosa (ARENDT, 1999, 2008b). De acordo com o relato de Arendt acerca do julgamento de Eichmann (1999), aquele assassino em massa não era um antissemita convicto que defendia, abertamente, o extermínio do povo judeu. E mesmo assim, na condição de burocrata nazista, que se representava a si mesmo como um ninguém, como um funcionário que só cumpria ordens, Eichmann foi capaz de enviar dezenas de milhares de judeus para os campos de concentração e de extermínio. Sua incapacidade de pensar e de julgar sobre o que estava fazendo lhe permitia ser, durante o dia, um assassino e, à noite, um cidadão de bem que, após uma jornada extenuante de trabalho, retornava para sua casa e se reunia, normal e humanamente, com sua família como se nada excepcional houvesse ocorrido. "O problema com Eichmann era exatamente que muitos eram como ele, e muitos não eram nem pervertidos, nem sádicos, mas eram e ainda são terrível e assustadoramente normais" (ARENDT, 1999, p. 299). Portanto, pode-se afirmar que, mesmo nesses momentos em que a luz do espaço público 
se torna tão opaca a ponto de desaparecer completamente, mesmo nesses momentos que, segundo Arendt (2008b), não são novos nem constituem uma raridade em nossa história, um homem ou uma mulher podem suspender temporariamente o exercício de sua capacidade de pensar e de julgar sem deixar de ser humano, de aparecer como pessoas normais. O que está em jogo na incapacidade de pensar e de julgar é a possibilidade de um ser humano se constituir como um alguém, uma pessoa capaz de exprimir sua distinção única e responder em nome próprio e por si mesmo e, ao mesmo tempo, de agir por convicção e em nome de algum princípio cuja grandeza se mantém essencialmente a mesma através dos séculos (ARENDT, 2004, 2013). "Sem dúvida, posso me recusar a pensar e lembrar, e ainda assim permanecer muito normalmente humana" (ARENDT, 2004, p. 159).

Embora tenhamos reiteradamente nos referido ao pensar $e$ ao julgar de maneira conjunta, é importante sublinhar que, para Arendt (2004, 2003), trata-se de duas capacidades distintas e inter-relacionadas. Em Pensamento e considerações morais, Arendt (2003, tradução nossa) afirma que o pensamento lida com invisíveis, com representação de coisas que estão ausentes (things that are absent) e o juízo sempre se refere a particulares e a coisas que estão próximas (things close at hand), isto é, coisas que, em sua proximidade, estão não apenas perto (close) de nós, mas à nossa mão (at hand) e, por isso, tornam-se utilizáveis no campo prático da existência humana ${ }^{23}$. Para Arendt (2003), o pensar e o julgar estão inter-relacionados de maneira similar ao modo como a consciência de si (consciousness) e a consciência (conscience) estão interconectadas. Essa analogia pode ser explicada, em parte, com base na distinção que a língua materna de Arendt opera entre Bewußtsein (consciousness) e Gewissen (conscience) ${ }^{24}$. Porém, podemos entender melhor essa analogia se nos atentarmos ao fato de a inter-relação entre o pensar e o julgar, de acordo com Arendt (2003), repousar na identidade pessoal de um alguém que, no dois-em-um do pensamento, responde para si mesmo sobre seus atos e suas palavras. Segundo Arendt (2003, p. 257, tradução modificada):

Se o pensar, o dois-em-um do diálogo silencioso, atualiza a diferença dentro de nossa identidade como ela é dada na consciência de si (consciousness), e desse modo resulta na consciência (conscience) como seu subproduto, então o julgar, o subproduto do efeito liberador do pensar, realiza o pensar, torna-o manifesto no mundo das

\footnotetext{
${ }^{23}$ É importante notar que, embora correta, a tradução da edição brasileira elide o sintagma at hand da expressão empregada por Arendt. Em nossa interpretação, essas coisas às quais o juízo no sentido arendtiano sempre se refere podem ser lidas na chave do utilizável (das Zuhandene), conforme a analítica do Dasein. Pois, na medida em que estão à nossa mão, elas podem ser usadas no campo prático seja para aplicar uma regra a casos particulares (juízo determinante) ou para delimitar, ao mesmo tempo, a regra e o caso particular (juízo reflexionante). Ver $\xi 22$. A espacialidade do utilizável do interior-do-mundo. In: Heidegger, M. Ser e Tempo, 2013.

${ }^{24} \mathrm{Na}$ segunda dissertação da Genealogia da Moral, Nietzsche haure dessa distinção a potência de sua crítica à "má consciência" (Schlechtes Gewissen) do escravo, reservando o termo Bewußtsein para a consciência do senhor; para "uma verdadeira consciência do poder e da liberdade" (ein eigentliches Macht und Freiheits-Bewußtsein).
} 
aparências, no qual nunca estou sozinha e sempre ocupada demais para ser capaz de pensar.

Para os nossos objetivos, o que nos interessa é destacar a importância dessa atividade reflexiva do pensamento sobre si mesmo para o sujeito da educação no processo de constituirse como um alguém. Ao lembrar de nossos atos e de nossas palavras, nosso eu pensante atualiza a diferença dentro de nossa identidade tal como ela é dada na consciência de si, porque, no diálogo silencioso consigo mesmo, ele não apenas se representa como um objeto do pensamento, mas representa o si-mesmo como outro (RICOEUR, 2014). Nessa representação que se dá na região da consciência de si, o eu pensante se desdobra em um interlocutor de e para si mesmo. E, nesse sentido, o dois-em-um, o diálogo silencioso consigo mesmo, pode ser lido como uma encenação dessa alteridade que está implicada na unicidade de um ser responsável, de um alguém que responde a si mesmo por seus atos e por suas palavras. Desse modo, pode-se dizer que essa alteridade, esse outro, atua no palco da consciência de si como um personagem e a atualização da diferença dentro da nossa identidade pessoal é, portanto, um desdobramento dessa alteridade, que está implicada na atividade do pensamento. Essa dobra que o eu pensante opera sobre si mesmo é, conforme Arendt (2003), o subproduto do pensar que resulta na consciência. É nessa outra região que, digamos, o eu judicante pode avaliar a atuação desse personagem que aparece para si mesmo como outro; pode, como se fosse um espectador de si mesmo, ajuizar seus atos e suas palavras como belos ou feios, justos ou injustos etc. Assim, na medida em que, para Arendt (2003), o julgar sempre se refere a particulares e lida com o que está ao alcance de nossas mãos, pode-se dizer que é nessa instância que o eu judicante confere realidade ao dois-em-um do pensamento.

Se, no teatro, a construção de um personagem envolve a preparação corporal e vocal do ator que, antes de entrar em cena, estuda as linhas de força que definem o caráter de sua persona dramatis (LECOQ, 2010); a constituição de um alguém envolve também a preparação de um ser igualmente distinto que, ao se familiarizar aos poucos com o mundo, exercita sua capacidade de pensar e de julgar. É nesse sentido que a educação pode ser lida, através do pensamento de Arendt, como o processo no qual, diante das obras e dos monumentos do passado, um ser humano novo se constitui como um alguém. Na medida em que um recém chegado ao mundo estuda os objetos da cultura, isto é, volta-se para esses objetos de modo atento e cuidadoso, ele não apenas pode aprender e conhecer os significados das heranças culturais do passado, mas também interpretar-se diante desses objetos, elaborar sua identidade pessoal a partir de seu encontro com esses objetos. Uma vez que, segundo Arendt (2013), um recém chegado no mundo é, na qualidade de sujeito da educação, um ser humano novo e em 
processo de vir a ser, pode-se afirmar, nas palavras de José Sérgio de Carvalho (2017), que é, por meio de experiências formativas que ele se constitui como um alguém. E essa constituição tem a ver com o fato de que, através do processo educativo, os mais novos podem entrar em contato lentamente com as coisas mundanas, materiais e simbólicas que herdamos sem nenhum testamento de nossos antepassados (ARENDT, 2013).

Ao estudar, ao dispor de tempo e atenção para se familiarizar com os objetos da cultura, um ser humano novo e em vir a ser sai em visita de homens e mulheres ilustres que reificaram seus pensamentos em obras e monumentos que constituem nosso mundo comum. Se, para Arendt (2013), a escola é a instituição que comumente interpomos entre a esfera privada do lar e a esfera pública do mundo, pode-se afirmar que a escola torna possível a instauração de um espaço e um tempo adequados para a educação, isto é, um lugar de ócio estudioso (LÓPEZ, 2020); um lugar capaz de abrigar um mundo comum que passa a existir entre nós e, ao mesmo tempo, de proteger a novidade que vem ao mundo a cada nascimento (ARENDT, 2013). Assim, se é pelo nascimento que um ser humano novo vem ao mundo, conforme Arendt (2013), é somente por meio do exercício de nossa capacidade de pensar e de julgar que um ser humano se constitui como um alguém. Em outras palavras, um recém chegado no mundo se torna uma pessoa quando ele se torna capaz de responder (re-spondere) às coisas mundanas que existe entre nós e, através de sua resposta, exprimir sua distinção única, sua identidade pessoal. E, ao se constituir como uma pessoa (persona), cujas palavras começam a ressoar (per-sonare) no mundo, um alguém pode aparecer no palco do mundo como um personagem e atuar, por iniciativa própria, na companhia de outras pessoas ${ }^{25}$.

Mas, para Arendt, como esse exercício fundamental para constituição de um alguém é possível? A atividade do pensamento exige um afastamento temporário do mundo. Assim, a fim de aparecer como um personagem para si e estabelecer o dois-em-um do diálogo silencioso consigo mesmo, é preciso se retirar do mundo de coisas tangíveis e fabricadas pelo artifício humano. Para que a atividade do pensamento seja possível, conforme Arendt (2000, 2003), é preciso estar a sós consigo mesmo (solitude). Seja para refletir acerca das coisas que se passam ao nosso redor ou daquelas que acontecem ao redor do mundo, esse afastamento que é exigido pelo pensar não se instaura apenas em relação às coisas que estão ausentes e são representadas

\footnotetext{
${ }^{25}$ Na conferência $O$ grande jogo do mundo, proferida em 1975, poucos meses antes de sua morte, Arendt nos lembra que o sentido originário da palavra pessoa provém do latim, persona, e significava a máscara que cobria o rosto individual do ator e indicava para o público o papel que ele representava em uma peça. "Nessa máscara, desenhada e feita para a peça, existia, entretanto, uma abertura larga, na altura da boca, pela qual podia soar a voz individual e indisfarçada do ator. É desse soar que se origina a palavra persona; per-sonare, soar por, é o verbo correspondente ao substantivo persona, máscara. E os romanos foram os primeiros a usar o nome em um sentido metafórico; na lei romana, persona era alguém que possuía direitos civis [...]" (ARENDT, 1993, p. 176).
} 
pelo pensamento, mas, no dois-em-um, o eu pensante estabelece uma distância em relação a si

mesmo. É, pois, precisamente nesse exercício de afastar-se de si mesmo para se aproximar das coisas do mundo, dos objetos materiais e simbólicos da cultura, que se abre a possibilidade de um afastamento do mundo para uma aproximação de si mesmo, e, assim, de refletir sobre o que fazemos e o que sofremos, de ajuizar e dar sentido às coisas particulares e que estão próximas de nós. É, pois, nesse exercício que nos constituímos como um alguém. Em outras palavras, é por meio desse exercício que um indivíduo deixa de ser visto simplesmente como um exemplar da espécie humana e nasce para o mundo como uma pessoa, como um alguém. Desse modo, ao aparecer para si mesmo como outro, um alguém pode reconsiderar o significado de obras e monumentos, de ações e discursos, pode reinterpretá-los e, ao mesmo tempo, reinterpretar-se diante deles (RICOEUR, 1986). Nesse sentido, pode-se dizer que uma pessoa pode alargar seu pensamento, aumentar sua potência de pensar, na medida em que é capaz de atribuir novos sentidos às relações que estabelece com os outros, com o mundo e consigo mesma.

Para Arendt (2003), na medida em que uma pessoa é capaz de se mover na dimensão de profundidade, de lembrar dos fragmentos cristalizados do passado e interpretá-los, ela pode deitar raízes no mundo e se estabilizar nele. Em outras palavras, é somente por meio do exercício de nossa plena capacidade de pensar e de julgar que podemos evitar o perigo de ser varrido pelo que possa vir a acontecer em nosso mundo. Isso significa que a privação da dimensão de profundidade não atinge apenas as atividades espirituais do pensamento e do juízo, mas também, do ponto de vista político, pode resultar em catástrofes para o mundo que possuímos em comum com os outros.

Para os seres humanos, pensar no passado significa mover-se na dimensão de profundidade, criando raízes e assim estabilizando-se, para não serem varridos pelo que possa ocorrer - o Zeitgeist, a História ou a simples tentação. O maior mal não é radical, não possuí raízes e, por não ter raízes, não tem limitações, pode chegar a extremos impensáveis e dominar o mundo inteiro (ARENDT, 2003, p. 160).

\subsection{Interpretar-se diante dos fragmentos do passado}

A partir dessas considerações, gostaria de colocar a problemática da ameaça de esquecimento no âmbito educacional da escola. Primeiro, é importante para os nossos propósitos não perder de vista que a invenção da skhole é um fenômeno histórico que nos dá a pensar sobre a origem e a potência da escola. Em Sobre a Revolução, Arendt (2011, p. 64) afirma que podemos identificar o surgimento de um fenômeno histórico (como, por exemplo, as revoluções, os regimes totalitários, o imperialismo etc.) descobrindo “[...] a primeira vez em 
que aparece a palavra que, a partir daí, passa a se vincular ao fenômeno". Assim, poderíamos dizer que a palavra skhole, seja ela uma nova palavra usada para designar uma experiência nova ou uma palavra velha empregada com significado absolutamente novo, aponta para o nascimento efetivo de um acontecimento histórico. Pois, conforme Arendt (2011, p. 64):

\footnotetext{
É óbvio que todo novo aparecimento entre os homens requer uma nova palavra, quer se cunhe um novo termo para designar a nova experiência, quer se utilize um termo antigo com significado totalmente novo. Isso se aplica duplamente à esfera política da vida, na qual a fala reina suprema.
}

Como veremos mais adiante, na medida em que a invenção grega da skhole liberava os cidadãos de suas obrigações políticas para com a cidade, esse fenômeno histórico suscitava um problema político. E, de acordo com Arendt (2013, p. 44), “[...] os problemas elementares da política jamais vêm tão claramente à luz, em sua urgência imediata e simples, como ao serem formulados pela primeira vez, e ao receberem seu desafio final".

Depois, é preciso considerar o fato de que, na escola, os professores, os alunos e o mundo estão inter-relacionados. Poderíamos afirmar, parafraseando João Wanderley Geraldi (2015), que toda escola define uma posição para cada um desses três elementos, dando ênfase ora a um, ora a outro desses elementos. Dessa maneira, quando se busca pensar a escola (suas práticas e seus níveis de significação) a partir dessa experiência subjacente à skholē, o que essa lembrança implica ou pode implicar para nós, professores e professoras? Que abertura no campo dos possíveis essa lembrança pode trazer para esse lugar no qual exercemos o ofício de apresentar aos alunos os objetos da cultura que julgamos dignos de permanecer no tempo? O que pode acontecer quando, no interior da escola, perdemos essa dimensão de profundidade, quando nos esquecemos desses fragmentos cristalizados do passado e nos conformamos com o estado atual dessa instituição interposta entre a casa e o mundo? Acaso para nós, professores e professoras, essa ameaça de esquecimento não colocaria em risco nossa própria dimensão de profundidade? Ou seja, na medida em que não podemos nos tornar professores e professoras senão no interior da escola, o esquecimento de seu sentido político e originário não significaria, em alguma medida, uma ameaça para a compreensão que temos de nós mesmos diante de nossos alunos e do mundo?

Diante do fio rompido da tradição, conforme Arendt (2013), estamos ameaçados de esquecimento. A impossibilidade de lembrar do sentido político e originário da escola implica, pois, um estreitamento no campo dos possíveis. Ou seja, com a perda de nossa dimensão de profundidade, pode-se afirmar, na esteira de Jacques Rancière (1988), que haveria certo consenso entre diferentes discursos sobre a ineficácia da escola. Ela seria ineficaz porque seu 
desempenho não corresponde à produtividade de uma sociedade de consumidores (ARENDT, 2015), porque seus processos e seus resultados não correspondem à positividade de uma sociedade do desempenho (HAN, 2017). A ineficácia da escola estaria associada, portanto, a uma defasagem em relação à sociedade. Esse atraso se manifestaria tanto no que diz respeito aos meios, aos modos como as relações educativas acontecem entre professores e alunos na escola, quanto aos fins, aos objetivos educacionais da formação escolar. E, nesse caso, diante de uma defasagem da escola em relação à sociedade, a saída consensual apontaria para uma tentativa paradoxal de acelerar o tempo da escola, de transformar o ritmo e a lógica da escola.

Para a racionalidade que funda o consenso sobre a ineficácia da escola, é preciso ajustar os ponteiros dessa instituição obsoleta com o relógio de uma sociedade produtiva, de uma sociedade que pode produzir sempre mais do que produz. Sua lógica é a da homogeneidade entre os tempos e os espaços. Tudo deve funcionar do mesmo modo e produzir no mesmo ritmo. Por isso a defasagem da escola seria um escândalo frente à vertiginosa produtividade de uma sociedade que não tem tempo a perder com coisas inúteis, que não tem valor no mercado de troca e, por isso, não servem para nada. Veremos que, para Rancière (1996), a prática do dissenso é uma invenção que torna possível a coexistência entre duas lógicas incompatíveis em um mundo comum. E, nesse sentido, a invenção da skholē nos oferece a possibilidade de conceber a escola não a partir de certo consenso sobre sua suposta ineficácia, mas como um espaço e um tempo heterogêneos à lógica produtiva da sociedade de consumidores cujo apetite pantagruélico devora tudo o que está ao alcance de suas mãos. Sem a lembrança dessa invenção, teríamos pouco espaço - talvez nenhum - para nos mover entre o passado e o futuro da escola.

O principal problema que um consenso sobre a ineficácia da escola suscita é o de que, mesmo despojados do fio da tradição, estaríamos presos a um aspecto predeterminado de uma imagem da escola que é projetada no futuro à semelhança de uma sociedade que pode produzir e consumir sempre mais. A instituição que, segundo Arendt (2013, 2015), era comumente interposta entre a esfera do lar e a esfera pública do mundo, ou seja, que estava relativamente protegida contra a lógica doméstica e contra a lógica da racionalidade política, encontra-se agora subordinada à lógica da produtividade do trabalho e do consumo. O ponto é que essa imagem distorce a localização da escola, dissolve a posição intermediária da escola para situala no âmbito do social. É como se o aspecto tangível do mundo que se abre através da escola para os mais novos evanescesse e o mundo de coisas interposto entre nós se manifestasse como algo consumível. A experiência escolar passa a ser vista, nesse sentido, não como iniciação a um modo específico de se relacionar com os objetos da cultura, mas como aquisição de objetos destinados ao consumo. E tudo o que não atende às necessidades da esfera social da vida 
humana deve ser reduzido ao mínimo possível ou, de preferência, eliminado da escola (poderíamos pensar, por exemplo, no desaparecimento do latim e do francês como línguas estrangeiras na escola).

Ocorre que essa imagem de uma escola eficaz, capaz de atender às necessidades do corpo social, não se desdobra apenas na relação dos mais novos com o mundo, mas também no modo como nós, professores e professoras, aparecemos e atuamos no palco da escola. Imaginemos um lugar sem aulas nem horários pré-fixados, sem professores nem alunos, no qual todos formariam uma verdadeira comunidade de seres que aprendem, um lugar no qual os conhecimentos estão disponíveis para além dos livros e sua transmissão independe da experiência de cada professor, no qual o mundo, ou melhor, as informações sobre ele podem ser acessadas a qualquer momento da palma de nossas mãos etc. Chamemos agora esse lugar de escola - sim!, pelo mesmo nome daquela instituição que, no Brasil, só foi universalizada no final do século XX e que conserva até hoje algumas práticas que datam do século XIX. Qual seria o papel do professor nessa escola? Claro, se ainda for possível falar em professor nessa escola. Seja como for, de que modo nessa escola os mais velhos respondem pelo mundo diante dos mais novos? Qual seria a atitude do professor diante do passado em uma escola cuja preocupação central aponta para o futuro?

A nova configuração da escola é mais do que uma tendência de certos discursos pedagógicos. Ela é uma exigência de uma sociedade de consumidores. Na lógica do consumo, a velha imagem da escola precisa ser periodicamente substituída por uma nova. As velhas práticas escolares que se sedimentaram ao longo de anos e que se repetem como ritos do passado precisam ser descartadas, não porque perderam seu significado, mas porque, em uma escola eficaz, tudo precisa ser atualizado. Nesse sentido, uma escola atualizada é uma escola ajustada às novas configurações da sociedade. Contudo, o paradoxo de uma escola eficaz é o de que seu desempenho pode sempre aumentar porque as necessidades da sociedade sempre aumentam. Ou seja, a atualização da escola é sempre uma projeção para o futuro, para um futuro que já chegou! Assim, as demais escolas, quando comparadas à essa imagem de uma escola eficaz e atualizada, seriam vistas como instituições ultrapassadas, instituições que não poderiam funcionar muito bem em nossos dias porque, devido ao seu desgaste natural com o passar do tempo, tornaram-se obsoletas. Essa defasagem seria, portanto, um traço constitutivo da ineficácia da escola.

Nesse sentido, a diferença entre os modos como a escola e a sociedade se relacionam com o passado apontaria supostamente para uma crise interna do dispositivo escolar. E os sintomas dessa crise se evidenciariam, por exemplo, através do caráter obsoleto da dimensão 
técnica da escola, pela obsolescência da tecnologia escolar (MASSCHELEIN; SIMONS, 2015). Assim, a ineficiência da escola poderia ser atestada pelo fato de que, por um lado, o professor ainda ensina usando lousa e giz, ainda aplica provas e exige respostas à caneta, ainda se preocupa mais com as matérias de estudo do que em desenvolver habilidades e competências, e, por outro, os alunos ainda copiam no caderno as lições do professor; ainda se sentam enfileirados uns atrás dos outros, são coadjuvantes em seu processo de aprendizagem. Porém, pensar a escola com base na invenção da skholē consiste precisamente em inventar um modo interessante de relação com as coisas do mundo, um modo atento e cuidadoso de se relacionar com os objetos da cultura, cuja permanência em nosso mundo comum depende de nossa atitude diante dos fragmentos do passado.

Ocorre que uma crise interna do dispositivo escolar não se restringe ao âmbito prépolítico das relações que ocorrem no interior da escola, isto é, às relações educativas nas quais o mundo se abre para os mais novos (MASSCHELEIN; SIMONS, 2015). Essa situação crítica cuja descrição se apoia na ineficácia de uma escola incapaz de atender as exigências da sociedade suscita, pois, um problema de natureza política. Ou seja, pôr fim a uma crise que concerne à escola depende de decisões políticas que são tomadas fora da escola. Por isso, certo consenso entre diferentes discursos sobre a ineficácia da escola aponta para a necessidade de reformar todo o sistema educacional, de instituir um novo currículo que atenda às novas exigências de uma sociedade em constante mudança e transformação, de tornar mais eficaz a gestão da escola, de atualizar a formação, inicial e continuada, do professorado etc. Não obstante, ainda que o problema seja de natureza política, em uma sociedade de consumidores, as decisões que estão pendentes e que precisam ser tomadas para pôr fim à suposta situação crítica da escola ensejam a iniciativa de empresas privadas que, mediante a oferta de produtos e serviços educacionais, apresentam soluções possíveis para aumentar o desempenho da escola $^{26}$.

\footnotetext{
${ }^{26}$ A pressão política exercida por diversas entidades privadas que culminou no movimento Todos pela Base é um bom exemplo de como a insegurança geral de uma situação crítica foi atravessada pela certeza de que, com a promulgação de uma Base Nacional Curricular Comum, a crise da escola estaria mais próxima do fim, sem que se soubesse ao certo nem quando nem de maneira ela chegaria ao seu fim (KOSELLECK, 1999). Não obstante, essas mesmas entidades (Instituto Unibanco, Instituto Ayrton Senna, Fundação Santillana, Fundação Lemann etc.) podem agora, em conformidade com a Base Nacional, oferecer seus produtos e serviços educacionais como se apresentassem uma solução possível para pôr fim à situação crítica da escola. "Pertence à natureza da crise que uma decisão esteja pendente, mas ainda não tenha sido tomada. Também reside em sua natureza que a decisão a ser tomada permaneça em aberto. Portanto, a insegurança geral de uma situação crítica é atravessada pela certeza de que, sem que saiba ao certo quando ou como, o fim do estado crítico se aproxima. A solução possível permanece incerta, mas o próprio fim, a transformação das circunstâncias vigentes - ameaçadora, temida ou desejada -, é certo. A crise invoca a pergunta ao futuro histórico" (KOSSELECK, 1999, p. 111).
} 
Para Arendt (2013), privados de nossa capacidade de pensar e de julgar, essa crise que atinge a escola seria vista inevitavelmente como um desastre. Nesse sentido, a lembrança do sentido político e originário da skholē pode surgir como um fragmento cristalizado do passado e iluminar nosso presente. É por isso que lembrar da origem e da potência da escola nos abre a possibilidade de pensar sobre os dilemas e os impasses que atravessam o cotidiano escolar. Para Arendt (2013), privados de nossa dimensão de profundidade, estaríamos igualmente privados da oportunidade de pensar sobre os problemas que emergem em uma crise, pois é somente em uma crise que os problemas passam a ser vistos como tais. Em outras palavras, pode-se dizer que, com a perda da memória do passado, os fenômenos originários que ficaram à sombra de nossa tradição permaneceriam esquecidos. E sem a lembrança desses fenômenos, estaríamos despojados de uma autêntica experiência de pensamento.

É oportuno observar, a esse respeito, o comentário de André Duarte sobre a origem do político no pensamento arendtiano. Para Duarte (2003), Arendt buscou ouvir a novidade que subjaz àquelas palavras que passaram a designar experiências políticas novas e que, embora ameaçadas de esquecimento, são repetidas diariamente em nossa linguagem cotidiana. Novidade que, antes da ruptura com a tradição, ninguém jamais teria tido ouvidos para ouvi-la (ARENDT, 2013). Segundo Duarte (2003, p. 81, destaque do autor):

\footnotetext{
É preciso ter em mente que tais fenômenos originários não constituem algo como uma gênese histórica capaz de estabelecer o começo de uma sequência linear de ocorrências no tempo; muito pelo contrário, a origem só se mostra enquanto tal no exato instante em que o suposto fluxo linear da história é suspenso e a terna reposição do mesmo dá lugar à invenção do novo na política, como nas modernas revoluções. Para Arendt, portanto, a origem do político não pode ser revivida enquanto mero dado ou enquanto um evento histórico concreto, mas só pode ser recuperada enquanto um fragmento descontextualizado e cristalizado nas palavras originárias: pólis, dynamis, isonomia, práxis, lexis, autoritas, potestas, res publica, constituto libertatis etc. Estas palavras dizem a origem democrático-republicana do político e referem-se a experiências políticas que, mesmo esquecidas em seu caráter original, subsistem ainda no coração do presente, podendo, portanto, irromper a qualquer momento.
}

A essa lista de palavras originárias, gostaríamos de incluir, portanto, a palavra skhole. Ainda que o caráter original desse fenômeno esteja ameaçado de esquecimento, sua potência pode ainda ser posta em ato. Se, para Arendt (2008b), enquanto usarmos a palavra "política", a pólis grega deve continuar a existir na base de nossa existência política; diremos, então, que, enquanto usarmos a palavra escola, a skhole deve continuar a existir na base de nossa responsabilidade coletiva pela conservação do mundo comum e pela novidade de cada nascimento.

Os defensores da escola do futuro poderiam levantar as seguintes objeções: para que recuperar o sentido originário de algo que não existe mais? Para que perder tempo (e dinheiro!) 
com algo cujo desempenho não pode ser avaliado objetivamente por meio de coletas de dados e análises estatísticas? Em resposta diremos, com base na análise de Jacques Rancière (1988, 2018), que pensar a origem e a potência da escola é abrir a possibilidade para inventar outros modos de se relacionar com o mundo. Essa abertura no campo dos possíveis para inventar outros modos de pensar a escola é também uma abertura para inventar outros modos do fazer, do dizer e do ser. Uma abertura por meio da qual os atores diretamente envolvidos nas relações educativas podem mudar suas ações no interior da escola e intervir de outro modo no curso das coisas (RICOEUR, 1986). Voltar nossa atenção para esse fenômeno originário, como bem observou André Duarte (2003), não significa reconstruir a gênese histórica da skholē. Recuperar o caráter original da skhole significa lembrar que a escola pode ser concebida de outras maneiras. Nesse sentido, à luz da interpretação arendtiana da parábola de Kafka, poderíamos dizer que a skholē como fenômeno originário nos põe em movimento no campo do pensar, tal como o adversário de Ele que o acossava por trás, da origem, no campo de batalha. A lembrança de fragmentos cristalizados do passado é o que torna possível o movimento do pensar. Sem ela, talvez permaneceríamos prostrados diante daquela imagem de uma escola ineficaz e sempre desatualizada em relação ao estágio de desenvolvimento produtivo da sociedade; daquela imagem de uma escola decadente e niilista cuja principal preocupação é a de se ajustar às exigências de uma sociedade de consumidores, na qual tudo o que existe passa a ser visto como um mero bem de consumo, inclusive aquelas coisas, materiais e simbólicas, que poderiam conferir ao nosso mundo comum alguma estabilidade e permanência.

\subsection{A invenção da skholē e a potência da escola}

Em A Condição Humana, Hannah Arendt (2015) examina a fonte e origem da distinção entre vita activa e vita contemplativa. Seu objetivo não era o de refutar a validade da experiência que subjaz à distinção entre cada um desses modos de vida. Tratava-se, antes, de pôr à prova a hierarquia tradicional estabelecida por essa distinção e analisar as consequências da progressiva indistinção entre as atividades humanas. Para Arendt (2015), o enorme valor conferido tradicionalmente à atividade da contemplação, a qual desde sua descoberta passou a caracterizar o modo de vida do filósofo, turvou as diferenças e as articulações entre as atividades humanas. $\mathrm{Na}$ interpretação arendtiana, a ruptura com a tradição abriu a possibilidade de questionar essa ordem hierárquica. E, para Arendt, essa abertura permitiu uma reconfiguração da ordem hierárquica no interior de seu próprio quadro de referência. Ou seja, com a perda da tradição, foi possível inverter a hierarquia entre as diversas atividades humanas. Porém, mesmo na 
ausência daquele fio que nos guiava pelos vastos domínios do passado, o estatuto da contemplação se manteve inalterado e continuou sendo o ponto de partida para a avaliação das todas as atividades humanas. Nesse sentido, para Arendt (2013), as modernas inversões promovidas por Marx e Nietzsche, as quais alçaram, respectivamente, o trabalho e a vida ao posto mais elevado das atividades humanas, apoiaram-se em um princípio abrangente único. Segundo Arendt (2015, p. 21):

A inversão moderna tem em comum com a tradicional hierarquia a premissa de que a
mesma preocupação humana central deve prevalecer em todas as atividades dos
homens, posto que, sem um princípio abrangente único, nenhuma ordem poderia ser
estabelecida. Tal premissa não é evidente, e meu emprego da expressão vita activa
pressupõe que a preocupação subjacente a todas as suas atividades não é a mesma
preocupação central da vita contemplativa, como não lhe é superior nem inferior.

É dentro dos limites dessa problematização que o pensamento arendtiano se depara com o fenômeno originário da skholē. Para Arendt (2015), a invenção da skhole foi uma consequência da descoberta filosófica da contemplação como uma faculdade distinta e superior às demais atividades humanas. $\mathrm{O}$ desprezo pela vita activa decorre, portanto, da primazia da contemplação, do pressuposto de que todas as atividades humanas devem ser avaliadas com base na preocupação central que orientava o modo de vida do filósofo. É daí que se estabelece, na interpretação de Arendt, a ordem hierárquica entre vita activa e vita contemplativa. Foi, portanto, contra essa hierarquia que Arendt (2015, p. 96) buscou “" [...] determinar, com alguma segurança, o seu [da vita activa] significado político".

Com a descoberta da contemplação, a preocupação do filósofo com o que é eterno se tornou não somente preponderante, mas passou a antagonizar com a preocupação do cidadão que estava voltada para o que é imortal, isto é, para a possibilidade de imortalizar seus atos e suas palavras. Assim, com base na premissa segundo a qual a mesma preocupação humana central deve prevalecer em todas as atividades humanas, a atividade da contemplação se tornou para os filósofos a medida de todas as coisas. Poderíamos afirmar, de acordo com esse princípio abrangente único, que a preocupação humana central se voltou para o que é eterno, ou seja, para aquilo que estava fora do tempo. Nesse sentido, a descoberta da contemplação tornou ainda mais robusta a atitude de desprezo que os gregos tinham tanto em relação à atividade do trabalho, cujos produtos eram destinados à satisfação das carências e das necessidades da vida, quanto em relação à atividade da fabricação, cujos artefatos produzidos por fabricantes mortais podiam conferir alguma estabilidade ao mundo humano (ARENDT, 2005).

Ocorre que, para Arendt (2015), essa atitude ascética do filósofo jamais poderia alcançar seu intento inicial, pois, na medida em que os filósofos reificavam e compartilhavam seus 
pensamentos com outros, havia sempre um elemento mundano no modo de vida filosófico. Assim, o objeto para o qual a preocupação dos filósofos estava voltada, a eternidade, se transfigura em algo adequado a ingressar novamente no mundo de seres mortais. Ainda que a preocupação dos filósofos estivesse voltada para o que é eterno, as obras filosóficas, embora não fossem destinadas ao uso como a maioria das coisas fabricadas por mãos humanas, dependiam igualmente do cuidado, do cultivo dessas obras, a fim de que pudessem permanecer no mundo. Em outras palavras, a permanência dessas obras no mundo somente pode ser alcançada através da transmissão desse legado aos recém chegados no mundo humano e comum. E, dessa maneira, a invenção da skholē pode ser vista, pelo pensamento arendtiano, como uma possibilidade para a existência de um lugar adequado no mundo cuja finalidade consiste em cuidar e cultivar essas coisas produzidas por seres mortais e que podem se imortalizar através de gerações.

É importante observar que, do ponto de vista da historiografia moderna, o período analisado por Arendt como fonte e origem da distinção entre vita ativa e vita contemplativa corresponde ao chamado período clássico do mundo grego (séculos V e IV a.C.). E suas reflexões acerca do início de nossa tradição de pensamento político, inaugurada pelo conflito entre o filósofo e a pólis, referem-se mais especificamente aos eventos ocorridos no período clássico de Atenas ${ }^{27}$. É por isso que, na interpretação arendtiana (2015), Platão é o fundador de nossa tradição de pensamento político. E na medida em que a rebelião dos filósofos contra essa tradição ao longo do século XIX se apoiava na inversão de suas categorias usuais dentro de seu próprio quadro de referência, pode-se dizer, conforme Arendt (2013), que as ideias platônicas não desapareceram totalmente no ocaso de nossa tradição de pensamento político. Segundo Arendt (2015, p. 23; 25):

\begin{abstract}
A preocupação dos gregos com a imortalidade resultou de sua experiência de uma natureza imortal e de deuses imortais que, juntos, circundavam as vidas individuais de homens mortais. Inserida em um cosmo onde tudo era imortal, a mortalidade tornou-se o emblema da existência humana. [...] é somente em Platão que a preocupação com o eterno e a vida do filósofo são vistas como inerentemente contraditória e em conflito com a luta pela imortalidade, que é o modo de vida do cidadão, o bios politikos.
\end{abstract}

\footnotetext{
${ }^{27}$ Poderíamos afirmar que, no escopo da análise arendtiana, o termo pólis geralmente se refere à cidade de Atenas do período clássico. É interessante notar que, em latim, os termos ciuis e ciuitas correspondem aos termos gregos $\pi o \lambda \imath \tau \dot{\zeta} \varsigma$ e $\pi \delta ́ \lambda \iota \varsigma$, respectivamente. E, em português, costuma-se traduzir os primeiros por cidadão e os segundos por cidade. Ocorre que o termo ciuitas designava também a condição de cidadão, ou que chamaríamos, hoje, de

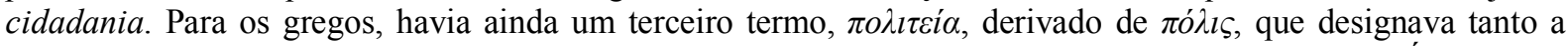
constituição de um corpo político específico quanto o modo de vida característico de seus cidadãos. É com base nessa correspondência que Platão sustentou, na República - que, aliás, é a tradução ciceroniana consagrada para o termo $\pi o \lambda \imath \tau \varepsilon i ́ \alpha$-, a tese de que os vícios e as virtudes de cada regime político podem ser encontrados no modo como vivem seus cidadãos.
} 
Para os nossos propósitos, a fim de delimitar o sentido originário da skhole no pensamento de Arendt, é importante sublinhar essa incompatibilidade que surge, em Platão, entre o modo de vida do filósofo e o modo de vida do cidadão. Não seria demasiado afirmar que, para Arendt, a skholē nasce dessa relação conflituosa entre o filósofo e a pólis. É somente com Platão que a filosofia precisou se refugiar para além dos muros da cidade. Esse refúgio da filosofia afastou o filósofo do mundo de coisas interposto entre ele e seus concidadãos. Assim, a preocupação central com o que é eterno, que caracterizava o modo de vida filosófico, tornouse o marco zero da nossa tradição de filosofia política. Logo, a busca e a aplicação de parâmetros filosóficos absolutos, ou seja, de critérios apolíticos e extramundanos para resolver os problemas da política e do mundo humano foram, nesse sentido, a resposta platônica para a tragédia da filosofia.

A atitude de desprezo e desconfiança do filósofo para com a vita activa, para com o modo de vida político no qual se buscava a excelência dos atos e das palavras e que podia imortalizar os homens nessa "[...] espécie de memória organizada [...]" que era pólis, surge como uma reação filosófica à hostilidade da política contra a filosofia (ARENDT, 2015, p. 245). Nossa tradição de pensamento político, na interpretação de Arendt (2015, p. 15), “[...] longe de abranger e conceitualizar todas as experiências políticas da humanidade ocidental, é produto de uma constelação histórica específica: o julgamento de Sócrates e o conflito entre o filósofo e a pólis". Portanto, à luz dessa interpretação, é possível identificar o início de nossa tradição de pensamento político com a reação filosófica de Platão aos eventos que culminaram na morte de Sócrates, de modo que as bases fundamentais dessa tradição podem ser encontradas na República.

Ainda conforme o pensamento de Arendt, a posterior distinção aristotélica entre os modos de vida, bem como sua recepção pelos filósofos da Antiguidade tardia e do medievo, é caudatária dessa tradição inaugurada por Platão. Contudo, para os nossos propósitos, gostaria de destacar um aspecto relevante da análise arendtiana. Na distinção aristotélica ${ }^{28}$ entre os três modos de vida, a saber, o do filósofo ( $\varphi \imath \lambda o ́ \sigma o \varphi o \varsigma)$, que se volta para a inteligência crítica ${ }^{29}$

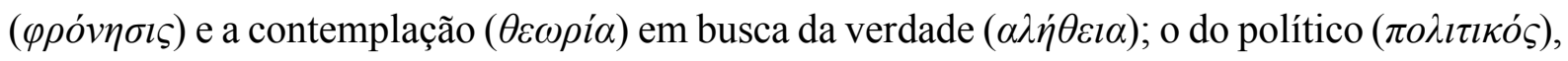

\footnotetext{
${ }^{28}$ Aristóteles. Ética Eudêmia, 1215a1-4.

${ }^{29}$ Em Aristóteles, o termo phrónēsis é também traduzido por prudência. Seja qual for a tradução, é importante sublinhar que, no pensamento aristotélico, o termo se refere a uma qualidade intelectual, conforme o estudo de Pierre Aubenque (2008). "Que Aristóteles faça da phronêsis, além disso, uma virtude, não impede que esta virtude não seja ética: ela é uma virtude da inteligência e não do ethos. O prudente serve de critério apenas porque é dotado de uma inteligência crítica. Ele não é somente aquele a partir de quem se julga, mas aquele que julga" (AUBENQUE, 2008, p. 85-6).
} 


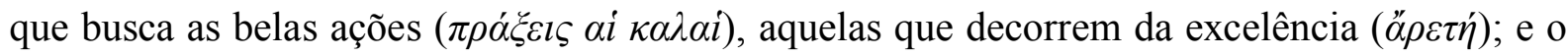
daquele que se dedica ao deleite ( $\dot{\alpha} \pi \mathrm{o} \lambda \alpha v \sigma \tau$ « $\sigma \omega \mu \alpha \tau \iota \kappa o \tilde{v})$, a liberdade está pressuposta como uma condição básica e elementar. Isto é, somente um homem livre podia adotar um desses modos de vida. Mesmo aqueles que seguiam uma vida dedicada ao deleite, e por isso, do ponto de vista filosófico, ocupavam uma posição inferior na hierarquia das atividades humanas, eram homens livres. Ou seja, ainda conforme a ordem hierárquica estabelecida a partir do modo de vida filosófico, esses homens que se dedicavam inteiramente aos prazeres do corpo continuavam sendo livres. E ainda que, para o filósofo, eles fossem vistos como escravos, é inegável que a escolha entre qualquer um desses modos de vida pressupunha a liberdade. Portanto, só metafórica e pejorativamente se podia dizer que o bon-vivant do mundo antigo, na medida em que estivesse sob o jugo do gozo e do deleite, estivesse privado da liberdade.

Para Arendt (2015), a liberdade era a condição pré-política para que um homem pudesse ser admitido no âmbito público da pólis. Para se tornar um membro da assembleia ( $\beta o v \lambda \varepsilon v \tau \eta ́$ s) e deliberar $(\beta o v \lambda \varepsilon v ́ \sigma \theta \alpha \imath)$ acerca dos assuntos relativos à pólis ( $\tau \dot{\alpha} \pi o \lambda \imath \tau \imath \kappa \alpha ́)$, era preciso ser livre

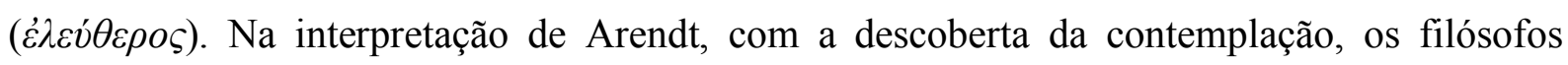
modificaram substancialmente essa noção de liberdade ( $\dot{\varepsilon} \lambda \varepsilon \dot{\varepsilon} \theta \varepsilon \rho i ́ \alpha)$. Ser livre não era apenas a condição para ser admitido no domínio público da pólis, mas passou a ser também a condição para a liberação de toda atividade política. Em outras palavras, ser livre se tornou a condição pré-política para a skholē que, do ponto de vista do filósofo, apontava para o único modo de vida digno de um homem livre. Originalmente, pode-se dizer que a invenção da skholē se mantém vinculada ao círculo da liberdade, ou, mais precisamente, que foi dentro desse círculo que os filósofos puderam inventar a skholē como liberação de toda atividade política ${ }^{30}$. Segundo Arendt (2015, p. 18):

\footnotetext{
${ }^{30}$ Seria difícil sustentar, com base no pensamento arendtiano, que a invenção da skhole como liberação de toda atividade política estivesse vinculada à liberdade. No ensaio Que é liberdade?, Arendt (2013) argumenta que a razão de ser da política é a liberdade e que seu domínio de experiência é a ação. Nesse sentido, conforme Arendt (2013), o exercício da liberdade se dá nos limites do domínio público no qual os seres humanos aparecem uns aos outros sob a modalidade da ação e do discurso. É somente em épocas de crise ou de revolução que a ação política se volta para a liberdade como um ponto de chegada. Para Arendt (2013), a liberdade é inerente à ação humana. E é somente como resultado da alienação do mundo que a liberdade se refugia no interior do ser humano, no eu (self). Assim, para Arendt (2013), a liberdade interior é um fenômeno tardio, isto é, um fenômeno derivativo da ação e descoberto, na Antiguidade tardia, por aqueles não possuíam mais um lugar próprio no mundo. No entanto, com base nas análises de Pierre Hadot (2014), é possível sustentar que a invenção da skholē estivesse originariamente vinculada à liberdade na medida em que essa liberação de toda atividade política possibilitava uma abertura para um modo de ser e de agir; para um modo de vida no qual, por meio de diferentes práticas, buscava-se meditar sobre o sentido da existência humana. No caso, por exemplo, de Sócrates, é inegável que sua perambulação pela cidade e seu desígnio de interrogar, inspecionar e refutar todos aqueles que eram reputados como sábios (Platão, Apologia, 29e) nunca foram vistos, por seus concidadãos como atividades políticas. "Não é preciso, pois, como se faz muito frequentemente, imaginar que a filosofia se transformou radicalmente na época
} 


\begin{abstract}
À antiga liberdade em relação às necessidades da vida e à coerção de outros, os filósofos acrescentaram a liberdade e a cessação de toda atividade política (skholē), de sorte que a posterior pretensão dos cristãos de serem livres de envolvimento em assuntos mundanos, de todos os negócios deste mundo, foi precedida pela apolitia filosófica da Antiguidade tardia, e dela se originou.
\end{abstract}

Para Arendt, o caráter apolítico da skholē no domínio da pólis é inerente ao modo de vida filosófico, pois sem essa deliberação, que tornava possível a liberação do filósofo de toda atividade política, a filosofia como um modo de vida seria impossível. A invenção da skhole torna possível a invenção de um tempo livre das atividades e obrigações políticas. É evidente que esse tempo livre não tem a ver com a noção moderna de lazer ou de passatempo - para a qual, aliás, os gregos dispunham do termo diatribē ( $\delta \imath \alpha \tau \rho \imath \beta \eta ́)$. A invenção da skhole atendia, pois, à dupla exigência para que a filosofia pudesse existir como um modo de vida na pólis: a liberdade e cessação de toda atividade política e, ao mesmo tempo, a liberdade do espírito para se dedicar ao que é eterno.

Tal como o latino otium, o termo grego schole não designa ócio como tal, mas ócio em relação à obrigação política, não participação na política; por conseguinte, a liberdade do espírito para ocupar-se do eterno (aei on), o que só é possível se as necessidades básicas da vida mortal estiverem atendidas (ARENDT, 2013b, p. 132).

Ocorre que, para Arendt, o filósofo não podia simplesmente abandonar a política. E, por mais que esse fosse o seu maior desejo, ele não podia delegar simplesmente as deliberações relativas à pólis aos seus concidadãos. Na interpretação de Arendt, após o julgamento e a condenação de Sócrates à pena capital, a pólis passa a ser concebida como um lugar perigoso tanto para os filósofos quanto para a própria filosofia. Em $O$ fim da tradição, Arendt (2013b) defende que a atitude de desprezo do filósofo pela política resultou em uma relação negativa com o domínio dos assuntos humanos, porém, jamais uma não relação. E, nesse sentido, à medida que a política se tornava uma ocupação cada vez mais indesejável para o filósofo, ela se torna, ao mesmo tempo, um objeto de pensamento inevitável para a filosofia. É por isso que, conforme Arendt (2013b), após o julgamento de Sócrates, e a despeito do ressentimento dos filósofos pela política, não havia outra maneira de salvaguardar a filosofia senão por meio da política. Renunciar ao governo da cidade seria, para Platão, o mesmo que abandonar a filosofia ao sabor da própria sorte - e o exemplo de Sócrates indicava, como um presságio, que a sorte

helenística, isto é, após a dominação macedônica das cidades gregas, ou na época imperial. Por outro lado, não houve, depois de 330 a.C., essa morte da cidade grega e da vida política que comumente se admite, sob a influência de clichês tenazes. E, sobretudo, a concepção da filosofia como arte de viver, como forma de vida, não está ligada a circunstâncias políticas, a uma necessidade de evasão, de liberdade interior que compensaria a liberdade política perdida. Já em Sócrates e em seus discípulos a filosofia é um modo de vida, uma técnica da vida interior. A filosofia não mudou de essência no curso de sua história na antiguidade" (HADOT, 2014, p. 267). 
da filosofia e de seu modo de vida correspondente não podia depender de ninguém a não ser dos próprios filósofos.

Se, para Arendt, o ato inaugural de nossa tradição de filosofia política se deu com a resposta platônica à hostilidade da pólis contra a filosofia, pode-se afirmar que, aos olhos de Platão, a solução para o problema da política fosse a de que a cidade pudesse ser governada por um filósofo. Lendo a República (476b-c) à luz da interpretação arendtiana, chegaríamos à conclusão de que somente "[...] aqueles que são capazes de subir até o belo e de o contemplar na sua essência [...]" podiam governar de modo a neutralizar os eventuais ataques da pólis contra a filosofia. Segundo Arendt (2013b, p. 134):

O apelo de Platão por um rei-filósofo não significa que a filosofia devesse, ou mesmo
pudesse, ser realizada num sistema de governo ideal, mas que os governantes que dão
mais valor à filosofia do que a qualquer outra atividade deveriam poder governar de
tal forma que pudesse haver filosofia, que os filósofos teriam schole e não seriam
incomodados por assuntos decorrentes das necessidades do convívio humano, que,
por sua vez, é originário, em última instância, das imperfeições da vida.

$\mathrm{Na}$ interpretação arendtiana, nem mesmo a distância que separava Aristóteles da filosofia política de seu mestre foi capaz de superar essa atitude de desprezo pela política. Para Arendt (2013b), desde o início de nossa tradição de filosofia política, os assuntos humanos foram despojados de sua dignidade, de sua significação no campo prático da existência humana. E o resultado desse despojamento foi o de que a ação política passou a ser vista, desde então, como um instrumento para atingir algo mais elevado que ela mesma. Poderíamos dizer, conforme as análises de Arendt (2015), que as categorias de meios e fim se estenderam do campo da fabricação, da poiēsis, para o campo da ação, da práxis (o caráter instrumental da política é, digamos, o ponto pelo qual podemos identificar ainda nos dias de hoje o vestígio dessa tradição de pensamento em certas correntes de filosofia política). Nesse sentido, de acordo com Arendt $(2015,2013 b)$, a reação dos filósofos contra a política, contra essa atividade que ocorre diretamente entre os homens e que busca fundar e preservar corpos políticos, resultou na instrumentalização da ação política e, por conseguinte, na perda de seu significado. O problema é que reação generalizada contra a política pode resultar na destruição do espaço público politicamente constituído e, por conseguinte, do espaço no qual a liberdade humana pode se manifestar. Segundo Arendt (2013, p. 195), sem um domínio público constituído de modo político, um espaço no qual os seres humanos podem aparecer sob a modalidade da ação e do discurso, “[...] falta à liberdade o espaço concreto onde aparecer".

O que nos interessa aqui é mostrar como, na interpretação de Arendt, a invenção grega da skhole abriu a possibilidade, para os homens livres, não apenas de renunciarem às suas 
obrigações políticas para com a pólis, mas resultou, sobretudo, na abertura de um novo modo de vida.

Em termos aristotélicos, a política é um meio de se atingir um dado fim; não tem finalidade alguma em si mesma e por si mesma. Mais do que isso, a finalidade específica da política é, de certa forma, o seu contrário, a saber, a não-participação nos assuntos políticos, schole em grego, a condição da filosofia, ou melhor, a condição da vida devotada à filosofia (ARENDT, 2013b, p. 133).

Independentemente da questão acerca do que seja a política para Aristóteles, pode-se afirmar, conforme Arendt, que o fenômeno originário da skholē como liberação das obrigações políticas para com a cidade possibilitou a existência de outro modo de vida e de convívio entre os homens livres.

Para os nossos propósitos, é importante sublinhar que a invenção da skhole tornou possível um novo modo de ser e de agir, uma nova maneira de compartilhar o mundo com os outros e de se relacionar com as coisas que passam a existir no mundo, mesmo que a preocupação dos filósofos estivesse voltada para fora dele. A invenção da skhole, como vimos, esgarçou a noção de liberdade a tal ponto que permitiu ao pensamento filosófico alçar voo em direção ao que é eterno. E, nesse sentido, pode-se dizer que a invenção da skholē tornou possível uma nova experiência temporal, que não decorria diretamente da experiência do eterno, subjacente à atividade da contemplação e que caracterizava o modo de vida do filósofo, mas da relação que o filósofo passou a estabelecer a partir de então com os objetos de sua preocupação. É, portanto, essa relação que gostaríamos de inscrever na potência da escola. Estar liberado de toda atividade política significava não somente suspender a urgência das deliberações políticas no seio da pólis, mas também dispor de tempo para pensar e refletir acerca dos objetos de sua preocupação. Dispor de tempo para pensar e de praticar o pensado, para lidar com o que é invisível, com representações de coisas que estão ausentes e para reificar esses pensamentos e compartilhá-los com seus iguais. E aqui, aos olhos de Arendt (2015), a preocupação central com a eternidade que distinguia o modo de vida filosófico de todos os demais se mostra, desde o início, ilusória, pois na medida em que não há nenhuma atividade humana que corresponda à experiência do eterno, o simples fato de falar ou escrever sobre o que é eterno arruinaria qualquer experiência que porventura se podia ter da eternidade. Ao dispor de tempo para pensar o que é eterno, para lidar com o que é invisível e com representações de coisas que estão ausentes, o filósofo precisa reificar e compartilhar seus pensamentos com seus iguais a fim dar autenticidade ao seu modo de vida.

Tendo por base essas considerações, pode-se afirmar que a invenção da skhole, a liberação de toda atividade política, viabilizou um modo de vida que consistia 
fundamentalmente em devotar-se ao estudo ${ }^{31}$. É nesse sentido que, para os gregos, a filosofia

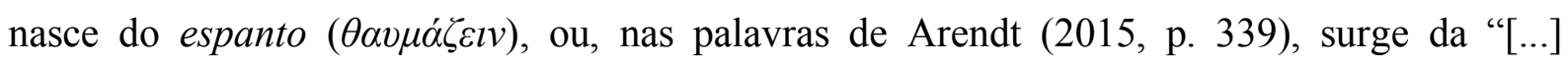
admiração diante de tudo o que é como é". Poderíamos dizer ainda que a experiência temporal do estudo subjaz à invenção da skhole, que o tempo liberado das atividades e obrigações políticas desagua no estudar, na atividade de dedicar nosso tempo e nosso esforço àquilo que nos espanta, àquilo que, ao mesmo tempo, nos assombra e nos admira. De acordo com as análises de Giorgio Agamben (1999), a palavra estudo está etimologicamente ligada à palavra espanto. Segundo Agamben (1999, p. 53-4):

Ela [a palavra studium] remonta a raiz $s t$ - ou $s p$-, que designa o embate, o choque. Estudo e espanto (studiare e stupire) são, pois, aparentados nesse sentido: aquele que estuda encontra-se no estado de quem recebeu um choque e fica estupefacto diante daquilo que o tocou, incapaz, tanto de levar as coisas até ao fim, como de se libertar delas. [...] Nada se assemelha mais a isso do que aquele estado que Aristóteles, opondo-o ao acto, designa de 'potência'.

Nesse sentido, poderíamos afirmar que se a escola é o lugar do estudo, então o estudo é o lugar da potência. Ou, ainda, nas palavras de Maximiliano López (2019, p. 77), que "o estudo é o lugar da experiência da própria potência [...]”. Para López (2019), a escola foi e pode continuar sendo um lugar de ócio estudioso. E, como tal, a escola teria mais a ver com estudo do que, propriamente, com aprendizagem. Para o autor, os termos estudo e aprendizagem possuem sentidos quase antagônicos. Segundo López (2019, p.75):

[...] a palavra aprender deriva do latim apprehendere que significa, literalmente, capturar. Por isso se pode dizer que um policial aprende um ladrão, porque na palavra aprender ressoam palavras como preensão, apreensão, presa ou prisão. O termo estudo possui um sentido quase antagônico, provém do latim estudium e tem o significado de cuidado, atenção, zelo, dedicação ou empenho, possuindo, além disso, o significado de afeto ( 'studia habere alicuius' queria dizer 'gozar do afeto de alguém').

Ocorre que, na escola, há algo que permite relacionar essas duas atividades que possuem, como vimos, sentidos quase antagônicos. Assim, pode-se afirmar que, ao estudar, somos capturados pelos objetos aos quais devotamos nosso tempo e nossa atenção. E, nesse sentido, a diferença entre estudar e aprender, para além do caráter instrumental da aprendizagem, repousaria, digamos, na relação epistêmica entre sujeito (o estudante) e objeto (a matéria de estudo). Em outras palavras, estudar é sujeitar-se aos objetos que são dignos de nossa dedicação e nosso empenho; e aprender é capturar esses objetos e, enquanto estiverem

\footnotetext{
${ }^{31}$ De acordo com Joaquim Brasil Fontes (2003, p. 29), "Skhólia é o nominativo plural do substantivo neutro skhólion ('comentário'), derivado de $\sigma \chi 0 \lambda \dot{\eta}=$ skhole, palavra com que os gregos significavam as coisas a que dedicamos nosso tempo, ou aquilo que merece o emprego do tempo. De onde, por meio de uma evolução notável, o sentido de 'estudo', encontrado em Platão. (Nas Leis, 820c, o termo skholē é aplicado às discussões científicas, por oposição aos jogos e brincadeiras.)".
} 
sob nosso domínio, sujeitá-los à nossa vontade. Os objetos podem ser os mesmos, mas o modo como nos relacionamos com eles é distinto em cada caso.

Em linhas gerais, poderíamos dizer, através do pensamento de Arendt, que a skholē inventa uma nova relação com o tempo e com o mundo. É então a partir dessa invenção que gostaria de tecer alguns comentários acerca da maneira como Jacques Rancière mobiliza o conceito de skhole e de como se desdobram as consequências dessa invenção.

\subsection{De como é possível pôr em ato a potência da escola}

No ensaio Ecole, production, égalité ${ }^{32}$, publicado em 1988, Rancière mostra que o caráter original da skholē consistia em renunciar aos privilégios e deveres políticos em favor do puro prazer de aprender. É esse uso do tempo, de acordo com Rancière (1988), que definia a skhole grega não apenas como tempo livre $d a$ atividade servil do trabalho, mas, sobretudo, como tempo livre para se dedicar, com vagar e ócio ${ }^{33}$, a esse puro prazer de aprender. Segundo Rancière (1988, p. 02, destaque do autor):

A scholé grega separa dois usos do tempo: o uso daqueles cujas obrigações do trabalho
e da produção retiram, por definição, o tempo de fazer outra coisa; e o uso daqueles
que têm tempo, ou seja, são dispensados das exigências do trabalho. Entre esses
últimos, há os que ampliam ainda mais essa disponibilidade sacrificando tanto quanto
possível os privilégios e os deveres de sua condição pelo puro prazer de aprender. Se
a scholé define o modo de vida dos iguais, esses "escolares" ("écoliers") da Academia
ou do Liceu, do Pórtico ou do Jardim, são os iguais por excelência.

Mas o que esse modo de vida dos iguais tem a ver com a escola de nossos dias? Para Rancière (1988), o que esse uso do tempo, a antiga skholē, tem em comum com a escola contemporânea é tão somente uma forma. É importante deixar claro que, com isso, Rancière não está definindo o acabamento da escola, isto é, o que uma escola deve ser enquanto escola. Não se trata, pois, de uma versão renovada da antiga ideia segundo a qual uma forma deve se impor sobre uma matéria inerte e amorfa. Então como podemos interpretar essa forma que, para Rancière, caracteriza tanto a skholē antiga quanto a escola contemporânea? Essa forma é, antes de tudo, uma abertura no campo dos possíveis. Essa forma aponta não para o que a escola deve ser, mas para o que ela pode ser. Nesse sentido, essa forma pode ser interpretada como a potência da escola. Por isso, segundo Rancière (1988, p. 02), a escola contemporânea pode ser

\footnotetext{
${ }^{32}$ Usamos, ao longo desse item, a tradução realizada pelo Grupo de Estudo e Pesquisa em Educação e Pensamento Contemporâneo (GEEPC-USP), a qual ainda não se encontra publicada. As páginas citadas, portanto, refere-se ao original.

${ }^{33}$ Joaquim Brasil Fontes (2003, p. 30) observa que "o advérbio skholēi indicava, para os gregos, o que dizem para nós as expressões: ‘com vagar e ócio'; 'lentamente'; 'à (sua) vontade”.
} 
vista à luz da skhole grega como "[...] uma forma simbólica, uma norma de separação de espaços, tempos e ocupações sociais". A escola como uma forma simbólica é, portanto, um lugar separado das necessidades da vida e da produtividade do trabalho, um lugar voltado para o puro prazer de aprender ou, se quisermos, um lugar voltado para o estudo, e, por fim, um lugar de verificação da igualdade. Essas são, segundo Rancière (1988), as três relações simbólicas fundamentais que caracterizam a forma escola.

Se, para Rancière, esse uso do tempo livre passa a definir o modo de vida dos iguais na medida em que reconfigura o espaço da igualdade no seio da comunidade política, é preciso pressupor, para tanto, uma distribuição de posições e de ocupações na pólis. Desse modo, não se pode negar que a invenção da skholē tinha como ponto de partida uma partilha do comum. Em outras palavras, segundo Rancière $(2018,2015)$, para que uns tivessem tempo e outros não, era preciso que houvesse uma partilha do sensível (partage du sensible), uma distribuição dos títulos e dos modos do ser que definia a ordem do visível e a ordem do dizível no seio da pólis. Ou seja, a skhole pressupunha uma partilha que determinava quem podia ter tempo e quem, constrangido pelas necessidades do trabalho, não podia; quem podia aparecer no espaço público e quem não podia; quem podia falar e ser ouvido como um igual e quem não podia. Ora, é evidente que, para Rancière, a skhole não abole toda e qualquer desigualdade nem inaugura o reino da igualdade na Terra. Não obstante, essa invenção permitiu uma reconfiguração na partilha do sensível na medida em que ela foi capaz de redefinir, no interior da comunidade, o lugar dos iguais a partir do uso do tempo. Diante disso, na interpretação de Rancière, os críticos da escola poderiam levantar as seguintes objeções: se a invenção da skhole se apoia na separação entre os que têm e os que não têm tempo, então a escola não estaria inscrita, desde sua origem, em uma ordem não igualitária? E se a relação entre a skhole grega e a escola contemporânea repousaria tão somente em uma forma, acaso ela não seria a da desigualdade? Se admitirmos, sem mais, essas objeções formuladas pelos críticos da escola, seríamos levados a concluir que a lógica escolar não apenas reproduziria a desigualdade existente na sociedade, mas também a produziria de modo específico no seio da instituição escolar.

A fim de explicitar o caráter original da invenção da skholē no pensamento de Rancière (2018), gostaria de sublinhar a distinção que o autor propõe entre polícia e política, isto é, entre ordem policial e atividade política. O próprio Rancière reconhece que essa denominação pode levantar objeções, pois, em geral, o termo polícia está associado às tropas militares e ao monopólio da força e da violência pelo Estado. Mas Rancière explica, a partir das análises de 
Michel Foucault ${ }^{34}$, que essa imagem à qual comumente associamos o termo polícia corresponde tão somente à baixa polícia. De acordo com Rancière (2018, p. 42), “a baixa polícia é apenas uma forma particular de uma ordem mais geral que dispõe o sensível, na qual os corpos são distribuídos em comunidade”. Para Rancière (2018), a polícia é a lei que define uma ordem dos corpos, que determina o lugar e a função de cada um na distribuição do sensível.

No caso da invenção da skhole, conforme a interpretação de Rancière, o uso do tempo livre reconfigurou a ordem policial vigente na pólis. Na medida em que a skholē separa, entre aqueles que têm tempo, os que se dedicam ao puro prazer de aprender, ela possibilita a abertura de um novo espaço de igualdade. Assim, através do pensamento de Rancière, pode-se dizer que, originariamente, o caráter político da skholē se apoia nessa separação que reconfigura a ordem policial; nessa operação que interrompe a lógica não igualitária e permite a criação de um espaço de igualdade no seio da comunidade. Em outras palavras, a skholē lança mão de um novo argumento para redefinir a distribuição do sensível. Ela sustenta que a igualdade repousa não apenas no fato de que uns têm tempo e outros não, mas, sobretudo, no uso do tempo daqueles que têm tempo. Ou seja, com base nesse argumento, a skholē vai demonstrar que a igualdade pode - e deve - ser definida não pela posse, mas pelo uso do tempo. $\mathrm{O}$ caráter original da forma escola consiste, portanto, no dissenso com a ordem não igualitária, na ruptura com a ordem consensual do tempo da produção. A potência da escola consiste em inventar um tempo heterogêneo, um tempo separado do trabalho, da produção e das necessidades da vida, o qual passa a existir simultaneamente ao tempo do trabalho, da produção e da vida. Nesse sentido, conforme a interpretação de Rancière, a invenção da skholē torna possível um certo modo do ser, do fazer e do dizer (uma certa relação com o tempo e com o mundo, uma certa relação consigo mesmo e com os outros) que permite a abertura de um novo espaço de igualdade no seio da comunidade.

Contudo, para que a potência da escola seja em ato, é preciso que ela manifeste um dissenso com a ordem não igualitária, crie um tempo e um espaço heterogêneos a fim de verificar as três relações simbólicas fundamentais que a caracterizam como uma forma simbólica. E, para Rancière, essa demonstração vai de encontro ao argumento da ordem

\footnotetext{
34 Jacques Rancière se baseia na conferência Omnes et singulatim: para uma crítica da razão política, proferida por Michel Foucault na Stanford University, em 1979. Nessa conferência, Foucault analisa a noção de polícia em voga nos séculos XVII e XVIII. Foucault vai mostrar, baseado especialmente na obra de Turquet de Mayenne, publicada na Holanda, em 1611, como a polícia era concebida, antes de tudo, como uma técnica de governo própria ao Estado moderno. Segundo Foucault (1990, p. 94), "Enquanto forma de intervenção racional exercendo o poder político sobre os homens, o papel da polícia é fornecer-lhes um pequeno suplemento de vida; ao fazê-lo, ela fornece ao Estado um pequeno suplemento de força. Isso é feito através do controle da 'comunicação', ou seja, das atividades comuns dos indivíduos (trabalho, produção, troca, acomodações)".
} 
consensual do tempo. Ou seja, ela jamais acontece à maneira cordial de um diálogo entre cavalheiros, como se os interlocutores se colocassem no debate político de comum acordo, a fim de pôr à prova seus argumentos. Para que ela seja vista e ouvida na interlocução política, é preciso encenar uma contradição entre a lógica policial e a lógica política. Para tanto, segundo Rancière (2018), a fim de manifestar uma cena de litígio, é preciso que um sujeito político interrompa o consenso da ordem não igualitária que funda a comunidade política. A capacidade de produzir cenas de litígio, de manifestar as contradições entre essas duas lógicas heterogêneas é chamada, por Rancière (2018), de subjetivação política. Para Rancière (2018, p. 54, destaque do autor):

Uma subjetivação política torna a recortar o campo da experiência que conferia a cada
um sua identidade como sua parte. Ela desfaz e recompõe as relações entre os modos
do fazer, os modos do ser e os modos do dizer que definem a organização sensível da
comunidade, as relações entre os espaços onde se faz tal coisa e aqueles onde se faz
outras, as capacidades ligadas a esse fazer e as que são requeridas para outro.

Assim, se, para Rancière, a polícia zela por uma ordem não igualitária que define a partilha dos modos do fazer, do ser e do dizer na comunidade; a política, ao contrário, provoca uma desordem nessa partilha ao verificar a igualdade daqueles que não são contados como iguais. A política é, nesse sentido, a atividade que reconfigura a partilha do sensível, que redistribui os corpos no seio da comunidade, que desclassifica as classes na hierarquia da ordem social (RANCIÈRE, 2018). Ela redefine uma nova topografia das posições e das funções, põe em jogo o que é próprio de cada um em uma dada comunidade.

Contudo, para Rancière (2018), a política como modo de exposição de um dano que funda a comunidade só se dá sob certas condições. É preciso que haja um espaço para a manifestação do dano e a política é precisamente a atividade que cria, que inventa, esse espaço por meio de um conflito. "O trabalho essencial da política é a configuração do seu próprio espaço” (RANCIÈRE, 2014b, p. 147, itálico do autor). Esse espaço no qual ocorre a atividade política surge do encontro conflituoso entre estas duas lógicas heterogêneas: uma que rompe com o consenso e afirma a igualdade dos que não são vistos e ouvidos como iguais e outra que resiste ao dissenso e nega essa igualdade dos desiguais. "A política encontra em toda parte a polícia. Deve-se pensar esse encontro como encontro dos heterogêneos" (RANCIÈRE, 2018, p. 45). A ordem policial recusa uma nova distribuição das partes às partes que não são contadas como partes porque não reconhece o litígio como fundamento da comunidade. Na lógica não igualitária da polícia, cada um tem o que merece ter, cada um ocupa ou, em tese, deveria ocupar o lugar que lhe é próprio. 
Em suma, pode-se dizer que, de acordo com Jacques Rancière (2018), a política expõe um dano, suspende o acordo consensual entre as partes e manifesta a contingência de uma certa distribuição dos modos do ser, do fazer e do dizer, isto é, ela reconfigura a partilha do sensível. Por outro lado, a polícia é a lei que interdita os modos de exposição desse dano que funda a comunidade e impede que a partilha do comum seja redistribuída de outra maneira. Assim, ao distribuir a cada um o que lhe é devido, ao repartir as partes de cada uma das partes, a ordem policial prescreve à parcela dos que não têm nenhuma parcela o direito de reivindicar uma nova partilha do comum. O consenso consiste em reverenciar essa lei que interdita outra partilha. Seja quais forem os títulos que conferem o direito de ser contado como parte em uma partilha do sensível, eles são sempre arbitrários; fundam-se na pura contingência do dano fundador de uma comunidade política. Se, para Rancière, a partilha que a ordem policial defende é uma partilha no campo dos possíveis, a atividade política é a própria manifestação dessa contingência. É nisto, pois, que consiste o dissenso: na exposição de um dano que é sempre contingente. Assim, ao manifestar esse dano, a política expõe a pura contingência do dano que funda a comunidade política e busca, por meio de uma cena de litígio que interrompe a lógica não igualitária da ordem policial, reconfigurar a partilha do sensível. É, portanto, essa encenação que torna possível a reconfiguração do sensível, como se, no seio da comunidade, houvesse um mundo comum no qual todos pudessem ser contados como parte. "Ora, só há política mediante a interrupção, mediante a torção primária que institui a política como o desdobramento de um dano ou de um litígio fundamental" (RANCIÈRE, 2018, p. 28).

À luz dessas considerações, vejamos então o que a invenção da skholē nos dá a pensar sobre a potência da escola. Para Rancière (2014b), é possível afirmar que a escola democrática seja a herdeira paradoxal da skhole aristocrática. Evidentemente, não se trata de afirmar que a escola pública e gratuita mantida pelo Estado possa vir a eliminar as desigualdades sociais e fazer cessar a lógica não igualitária que permeia toda sociedade. Mas tampouco se pode negar que, como forma simbólica, a escola já é a manifestação de um dano. Ao acolher crianças e jovens de diferentes classes sociais, gêneros, orientações sexuais, cores, etnias etc., a escola igualiza esses recém chegados no mundo e opera, desse modo, uma redistribuição do sensível e cria um novo comum. Mesmo que a coexistência de um sistema público e de um sistema privado torne a desigualdade mais evidente no caso brasileiro, é muito provável que, ainda nos dias de hoje, o filho de um mecânico, se não fosse à escola, estaria ajudando seu pai na oficina e que a filha de uma empregada doméstica, se não fosse a escola, estaria cuidando de seus irmãos até o retorno de sua mãe, que, ao chegar em casa, terá de recomeçar uma nova jornada de trabalho. Graças à escola, todo recém chegado no mundo tem o direito de se tornar aluno e, 
portanto, de potencialmente devotar seu tempo e seu esforço ao estudo; de aprender pelo puro prazer de aprender. Como forma simbólica, a escola inventa um lugar adequado para a transmissão e conservação de uma herança do passado (obras culturais, artísticas, científicas, filosóficas etc.) não para que os alunos possam transformar, no futuro, a vida política do país ou melhorar financeiramente suas próprias vidas, mas para que esse espaço e esse tempo separados da lógica produtiva possa transformar, no presente, o modo desses alunos se relacionarem com o mundo e com si mesmos. Como uma norma de separação, a escola possibilita aos alunos a fruição dessas obras, abre a possibilidade de uma relação de admiração, de espanto, com nossa herança do passado. Por isso a lógica da escola é diametralmente oposta à lógica da produção e do consumo, pois, de acordo com Rancière (2014b, p. 62), a escola “"[...] igualiza aqueles que acolhe, menos pela universalidade do saber que distribui ou pelos seus efeitos de redistribuição social, do que pela sua própria forma, que é a da sua separação relativamente à vida produtiva".

Acontece que essa separação do mundo do trabalho e da lógica produtiva nem sempre ocorre e a lógica não igualitária que permeia toda comunidade pode não cessar no interior da escola. Não raro, a escola é acusada por não se ajustar à lógica do mercado e da produtividade, por perder tempo com coisas inúteis que não auxiliam em nada a melhora do desempenho escolar. Quando a escola se esquece de fechar seus portões, de proteger esse espaço e esse tempo heterogêneos, nos quais se pode verificar a igualdade de qualquer pessoa com qualquer pessoa, a norma de separação que caracteriza essa forma simbólica está temporariamente suspensa. E quando a lógica da produção e do consumo invadem a escola, o mundo de coisas interposto entre nós deixa de ser visto como algo que possuímos em comum, que compartilhamos com os outros e se converte em um mero bem de consumo destinado a satisfazer as carências e as necessidades da sociedade ou da vida individual (ARENDT, 2015).

A forma escola é, como vimos, uma potência. Ela torna possível - o que não implica sua efetividade de - separar os tempos, os espaços e as ocupações; igualizar os que acolhe como alunos. Essa norma de separação é a condição para que a escola seja o palco no qual a lógica igualitária pode ser encenada. Nesse sentido, poderíamos afirmar que a política da escola consiste precisamente na atualização da sua potência, isto é, na encenação de suas relações simbólicas fundamentais. Assim, a política da escola não se resumiria apenas ao ato de encenar, mas abrangeria também a produção da própria cena (RANCIÈRE, 2018). É, portanto, essa encenação que pode instaurar o dissenso com a lógica produtiva, que pode conservar a escola como um lugar de estudo e que pode demostrar o argumento da igualdade das capacidades. É, portanto, nessa encenação que a potência da escola vem a ser em ato. 
Mas o que significa essa potência? Ou ainda, em que sentido se pode dizer que uma escola é potente? Com base nas análises de Giorgio Agamben (2017), pode-se afirmar que, desde o pensamento aristotélico, a potência aponta para a presença de algo que não é em ato. Assim, uma escola é potente não no mesmo sentido de que uma criança o é. Dizer que uma criança é potente significa que ela pode vir a ser tanto uma arquiteta quanto uma musicista. A potência da criança é, de acordo com Agamben (2017), uma potência genérica. Ora, a potência da escola não é uma potência genérica. Uma escola pode suspender temporariamente sua forma e se transformar em uma zona eleitoral no dia da eleição ou em um hospital de campanha durante uma guerra, mas ela jamais poderá se tornar um supermercado ou uma agência bancária. Ou seja, a escola está sujeita a eventos exteriores a ela que podem interromper sua lógica, mas a lógica escolar não pode ser substituída pela lógica do mercado ou pela lógica dos juros sem obliterar a potência escola. Assim, pode-se afirmar, de acordo com Agamben (2017), que uma escola é potente no mesmo sentido de que uma arquiteta e um musicista o são. Ela possui a presença de algo que pode ser em ato, ou, se quisermos, conforme Rancière (1988, 2018), ela possui uma forma simbólica que pode ser encenada. Isso não significa que exista um modo único de que a potência da escola seja posta em ato. Ao contrário, essa potência aponta para uma abertura no campo dos possíveis. Uma escola é potente na medida em que ela é capaz de expor um dano, de manifestar a cena de um litígio, e inventar a si mesma como um lugar adequado ao cuidado e ao cultivo das coisas que julgamos dignas de permanecer no mundo (RANCIÈRE, 2018; ARENDT; 2015).

A potência da escola é a possibilidade de inventarmos um tempo e um espaço heterogêneos à ordem não igualitária da lógica da produção e do consumo, de produzirmos cenas de igualdade no drama não igualitário encenado cotidianamente no palco escolar (RANCIÈRE, 2018). Se a política da escola consiste, como vimos, no dissenso com a ordem consensual de um tempo homogêneo no qual o futuro é agora, nos modos de manifestar a contingência que interdita uma abertura no campo dos possíveis, é porque somos capazes de agir, como animais políticos, em nome de princípios que, segundo Arendt (2013, p. 199), “[...] se manifestam no mundo enquanto dura a ação e não mais". Nesse sentindo, diremos que, situados no mundo da escola, isto é, nos limites do exercício de nosso ofício de professor, podemos pôr em ato a potência da escola, podemos atuar e atualizar os princípios que inspiraram a invenção grega da skholè. Assim, tanto a potência da escola quanto os princípios colocados em ato na invenção da skhole, ao contrário dos objetos de uso, não se desgastam ao se manifestarem no mundo, nem desaparecem inexoravelmente com o passar do tempo, como os objetos destinados ao consumo. É por isso que, na qualidade de uma forma simbólica, a 
escola foi capaz de permanecer em nosso mundo através de gerações: porque sua potência e os princípios que a inspiraram mantêm sua força e seu vigor na medida em que são atualizados. E por isso, sob certas condições, eles podem sempre ser colocados em ato. Essas condições muitas vezes não estão dadas, mas precisam ser elas mesmas inventadas por seres capazes de iniciar algo novo no mundo. "Os homens são animais políticos porque eles são animais poéticos, e é se dedicando a verificar, cada um por si próprio, essa capacidade poética compartilhada que eles podem instaurar entre eles uma comunidade de iguais" (RANCIÈRE, 2017, p. 96).

Assim como um arquiteto não perde sua potência enquanto ele não põe em ato a arquitetura, uma escola não perde sua potência enquanto suas relações simbólicas fundamentais estiverem temporariamente suspensas. É precisamente nesse instante, quando a linha que separa os espaços e os tempos escolares se torna invisível, que a presença privativa da escola pode se manifestar. É nesse instante, em momentos de crise, que o espaço e o tempo da escola podem ser pensados de outras maneiras, podem ser reconfigurados de outros modos. É nesse instante que a política da escola pode se opor à polícia da escola. E quando isso acontece, quando a potência da escola é posta em ato, ou, conforme $\mathrm{Arendt}^{35}$, quando a escola se torna um lugar adequado para a atividade da educação, cada um de seus atores é capaz de pôr em ato sua própria potência. De acordo com a interpretação de Agamben (2017), a potência não passa ao ato sofrendo uma destruição, mas um acréscimo. Portanto, pode-se afirmar que posta em ato, a potência da escola sofre um acréscimo. Ela aumenta na medida em que é posta em movimento por pessoas que agem em nome de princípios que se manifestam somente no ato de sua realização (ARENDT, 2013). A encenação de suas relações simbólicas fundamentais é o dom extremo da potência da escola. "Trata-se de partir do ponto de vista da igualdade, de a afirmar, de trabalhar a partir de seu pressuposto para ver tudo o que ele pode gerar, para maximizar tudo o que é dado em termos de liberdade e de igualdade" (RANCIÈRE, 2014b, p. 59).

\footnotetext{
${ }^{35}$ Para Arendt (2015, p. 61), “[...] nenhuma atividade pode tornar-se excelente se o mundo não proporciona um lugar adequado para o seu exercício".
} 


\section{CONSIDERAÇÕES FINAIS}

Ao longo dos três ensaios, emergiram algumas ideias e imagens de pensamento que, articuladas entre si, poderiam ser consideradas como definições programáticas sobre a educação e a escola, isto é, como definições que expressam uma deliberação moral e tencionam dar expressão a uma programação de ação (SCHEFFLER, 1974). Isso não significa que buscamos formular aqui uma teoria sobre a educação e a escola. Tais definições não buscam atingir a verdade de um determinado objeto, nem expressar a essência de algo por meio de demonstrações dedutivas ou axiomáticas, mas, com base em "argumentos porfiados que, nas palavras de Max Bense (2014), articulam-se discretamente por meio da repetição incansável”, elas buscam dar forma a certas convicções às quais se pode chegar somente depois de um longo e demorado exercício de pensamento. Para Arendt (2013), o único objetivo desse tipo de exercício é o de adquirir experiência em como pensar, de modo que eles jamais podem prescrever o que pensar ou que verdade defender.

À medida que buscamos pensar e reificar nossos pensamentos sobre a educação e a escola, suspendemos a questão da verdade e tentamos compreender o que estamos fazendo e o que estamos sofrendo quando aparecemos por iniciativa própria no mundo na qualidade de educador ou, se somos vistos no âmbito da escola, na qualidade de professor. É evidente, nesse sentido, que a escolha desses objetos não foi arbitrária, nem aleatória. Assumimos, com Arendt (2013, p. 41), que “[...] o próprio pensamento emerge de incidentes da experiência vivida e a eles deve permanecer ligado como os únicos marcos por onde pode obter orientação". Se quisermos ainda, podemos dizer, com Ricoeur (1982), que nos situamos em um conflito de interpretações, no qual, ao desdobrar os níveis de significação implicados na atividade da educação, somos intérpretes e, ao mesmo tempo, seres-interpretados. À guisa de conclusão, gostaríamos de reunir essas convicções que foram se desenhando na trama da escrita e que podem agora interpelar o leitor sobre o sentido da educação e da escola (BENSE, 2014).

A educação é a atividade por meio da qual acolhemos os mais novos em nosso mundo comum. Ela jamais se reduz à transmissão do conhecimento, ao ensino de conteúdos ou ao desenvolvimento de habilidades e competências. Acolher os mais novos em nosso mundo comum implica assumir a dupla responsabilidade pelo mundo e pelos recém chegados, pela continuidade das coisas que podem permanecer entre nós através de gerações e pela preservação da novidade que vem ao mundo a cada nascimento. É nesse sentido, conforme Arendt (2013, 
p. 223), que "[...] a essência da educação é a natalidade, o fato de que seres nascem para o mundo", pois a cada nascimento um novo mundo em potencial vem a existir (ARENDT, 2012), um novo começo para o mundo é possível porque, com o constante influxo de seres humanos novos e em processo de vir a ser, podemos renovar a fé e a esperança no único milagre capaz de salvar o mundo humano de sua ruína natural, a saber, a capacidade de romper o curso automático da vida cotidiana e, junto aos outros, dar início a algo novo, isto é, agir (ARENDT, 2015). A ação é como um segundo nascimento, pois, segundo Arendt (2015), somos inseridos pela concepção e nascimento em um mundo que nos é estranho, e, ao agirmos, nos inserimos por iniciativa própria em um mundo com o qual já temos alguma familiaridade. Na medida em que confirmamos nosso aparecimento físico original mediante atos e palavras, podemos exprimir nossa distinção única e responder quem somos nós. Ao aparecer uns aos outros na modalidade da ação e do discurso, podemos revelar ativamente nossa identidade pessoal única. Para nós que assumimos a responsabilidade de educar os mais novos, a atividade da educação é um modo de aparecer ativamente para o mundo e revelar quem somos nós diante desses recém chegados cuja tarefa consiste em renovar nosso mundo comum (ARENDT, 2013).

A atividade da educação é um pôr-se a caminho da pergunta que se faz a todo recém chegado: quem és? A revelação do quem ocorre, segundo Arendt (2015), quando os seres humanos se reúnem e instauram um espaço no qual aparecem uns aos outros; um espaço de aparência e visibilidade. Assim, esse ser único e igualmente distinto de todos os demais se revela à medida que aparece para os outros mediante atos e palavras. Ou seja, ele exprime sua identidade pessoal única ao se inserir por iniciativa própria no mundo. Porém, ao agirmos, não podemos dispor de nossa identidade pessoal tal como dispomos de nossas qualidades e talentos. Porque, conforme Arendt (2015), o quem se manifesta enigmaticamente para o agente, assim como os oráculos se manifestavam para os consulentes do mundo antigo. A manifestação da essência viva de um alguém se revela no fluxo da ação e do discurso e, portanto, a revelação do quem pressupõe a existência de seres humanos que potencialmente são capazes de agir, isto é, de seres humanos que já possuem certa familiaridade com o mundo e podem iniciar ou não iniciar algo novo (ARENDT, 2015; AGAMBEN, 2017). Para um ser humano novo e em processo de vir a ser, o quem se revela paulatinamente na relação que estabelece consigo mesmo diante dos outros e dos objetos da cultura. Ao longo do processo educativo, o sujeito da educação vai elaborando narrativamente sua identidade pessoal única diante da pluralidade de seres igualmente distintos e únicos; vai se familiarizando com as obras e os monumentos do passado; vai se identificando com enredos e personagens que passam a compor suas próprias estórias de vida. No decurso do processo educativo, os mais novos têm a oportunidade de se 
apropriar à distância das heranças culturais do passado. E nesse jogo entre estranhar o que é próprio e tornar próprio o que é estranho, o sujeito da educação vai se constituindo como um alguém.

A educação é a atividade por meio da qual os mais novos se familiarizam com os objetos da cultura. Familiarizar-se com os objetos culturais significa criar laços simbólicos com as coisas duráveis que podem permanecer no tempo e conferir confiança e estabilidade ao nosso mundo (ARENDT, 2015; LAJONQUIÈRE, 2010). Alguns desses objetos, as obras de arte, são particularmente interessantes para a tarefa da educação. As obras de arte são as coisas menos úteis que existem no mundo e, sob certas condições, podem permanecer ao longo de eras. Para os mais novos, familiarizar-se com as obras de artistas, cientistas, filósofos, historiadores etc. significa fazer sociedade com homens e mulheres que nos legaram toda sorte de coisas inúteis e, ao mesmo tempo, belas e memoráveis. "Sem a beleza, isto é, a radiante glória na qual a imortalidade potencial é manifestada no mundo humano, toda vida humana seria fútil e nenhuma grandeza poderia perdurar" (ARENDT, 2013, p. 272).

A educação é a atividade por meio da qual apresentamos aos mais novos as coisas materiais e simbólicas do mundo que possuímos em comum. Ao assumirmos a tarefa de educar os mais novos, aparecemos para o mundo como educadores e educadoras, e, se somos vistos no âmbito da escola, aparecemos como professoras e professores. Ainda que, para Arendt (2013, p. 238), “[...] a escola não é de modo algum o mundo e não deve fingir sê-lo [...]”, quando aparecemos para o mundo seja na qualidade de educadores ou de professores, nos tornamos responsáveis pelo modo como o espetáculo do mundo é apresentado aos mais novos, isto é, assumimos a responsabilidade pela escolha de quais coisas e de que maneira elas serão apresentadas aos mais novos. Por isso, ao endereçar a palavra para aqueles que acabaram de chegar no mundo, falamos sempre em nome próprio. E à medida que atuamos como educadores ou professores apresentando aos mais novos um mundo de coisas interposto entre nós, revelamos nossa identidade pessoal única e, assim, manifestamos o aspecto ético da educação. Diante do espetáculo do mundo que se descortina ao longo do processo educativo, o sujeito da educação deve assumir temporariamente a posição de espectador, a fim de estabelecer um modo de relação atento e cuidadoso com as coisas do mundo que são dignas de permanecer através de eras.

A atividade da educação é uma resposta específica a uma pergunta específica colocada por nossa condição temporal de seres mortais. Nascemos como seres finitos e dotados de uma capacidade infinita de iniciar algo novo no mundo. Nascemos também como seres inacabados, como seres novos e em processo de vir a ser. A educação pode ser vista, nesse sentido, como 
um tempo oportuno para que os seres novos que acabam de chegar no mundo possam se familiarizar com as coisas velhas que existem entre nós, com as estórias que resultaram da ação e do discurso que ocorrem entre seres únicos e igualmente distintos e que podem ser contadas e recontadas de diferentes pontos de vista. À medida que os recém chegados vão criando laços simbólicos com as obras e os monumentos do passado, com as coisas do pensamento que podem permanecer através de eras, abre-se um mundo comum entre vivos e mortos, um espaço-entre no qual os mais novos podem ter a experiência do imortal, podem ter um certo pressentimento de imortalidade na presença de algo que já existia quando chegaram e deve continuar depois de partirem. À medida que os mais novos vão se identificando com os objetos da cultura, com os enredos e os personagens, reais e de ficção, que atuaram no espetáculo do mundo, eles podem ser afetados pelos mesmos princípios que inspiraram a ação de homens e mulheres que apareceram e desapareceram antes de nós. Uma vez que as estórias dessas pessoas que deixaram algo digno de ser lembrado são apresentadas aos mais novos e passam a compor o enredo de suas estórias de vida, pode-se dizer que a atividade da educação contribuiu para a constituição de um alguém.

A escola é o lugar adequado para atividade da educação na medida em que apresenta aos mais novos o mundo humano e comum a partir de uma pluralidade de pontos de vista para uma multidão de espectadores. Para que a escola se torne um lugar adequado para educação é preciso antes que o compartilhar o mundo com os outros seja sua condição de possibilidade. Nada que existe no mundo pode ser interdito pela lógica igualitária e até mesmo aquilo que supostamente pode pôr em perigo o espaço e o tempo da escola, ao ser apresentado como algo que possuímos em comum, torna-se objeto ou matéria de estudo. Isso significa que toda tentativa de interditar certos temas e assuntos no interior da escola é espúria à lógica escolar, de modo que projetos de lei como, por exemplo, o Escola sem partido - além de ser absurdo e abjeto - é uma contradição em termos. Na medida em que algo que possuímos em comum é apresentado aos mais novos na qualidade de objeto ou matéria de estudo, ele passa a ser visto por uma pluralidade de pontos de vista. Somente uma política deliberada de censura pode evitar que algo apareça sob aspectos diferentes para uma multidão de espectadores.

A potência da escola é uma presença privativa que pode ser posta em ato na medida em que é possível encenar suas relações simbólicas fundamentais, a saber, a separação dos espaços, dos tempos e das ocupações sociais; o puro prazer de aprender; e a verificação da igualdade (RANCIÈRE, 1988). Ao encenar essas relações, a escola põe em ato uma forma, configura um espaço e um tempo nos quais a presença de uma lógica igualitária é possível. É, portanto, essa encenação que pode instaurar o dissenso com a lógica produtiva, que pode 
conservar a escola como um lugar de estudo, e que pode demostrar o argumento da igualdade das capacidades. Dessa maneira, a potência da escola pode ser vista como uma abertura no campo dos possíveis para que a encenação dessas relações simbólicas fundamentais possam ser postas em ato por aqueles que, por iniciativa própria, assumiram a responsabilidade de educar os mais novos. 


\section{REFERÊNCIAS}

ADORNO, Theodor. Ensaio como forma, O. In: de Almeida. São Paulo: Duas Cidades; Editora 34, 2003. . Notas de literatura I. Trad. Jorge

AGAMBEN, Giorgio. Ideia de prosa. Trad. João Barrento. Lisboa: Edições Cotovia, 1999.

Potência do pensamento, A: ensaios e conferências. Trad. António $\overline{\text { Guerreiro. } 1^{\mathrm{a}} \text { ed.; }}{ }^{\mathrm{a}}$ reimp. Belo Horizonte: Autêntica Editora, 2017.

AGUIAR, Odilio A. Espectador como metáfora do filosofar em Hannah Arendt, O. In: CORREIA, A. (coord.) Transpondo o abismo: Hannah Arendt entre a filosofia e a política. Rio de Janeiro: Forense Universitária, 2002.

ALAIN (CHARTIER, Émile). Reflexões sobre educação. Trad. Maria Elisa Mascarenhas; revisão técnica José Aluysio Reis de Andrade. São Paulo, 1978.

ALMEIDA, Vanessa S. Natalidade e educação: reflexões sobre o milagre do novo na obra de Hannah Arendt. In: Pro-posições, vol. 24, n. 2 (mai.-ago.), pp. 221-237, 2013.

. Amor mundi e educação: reflexões sobre Hannah Arendt. Tese (Doutorado em Educação) - Faculdade de Educação da Universidade de São Paulo, São Paulo, 2009.

ARENDT, Hannah. Between past and future: six exercises in political thought. New York: The Viking Press, 1961.

. Life of mind, The. New York: Harcourt Brace Jovanovich, 1981.

Humam Condition, The. Introduction by Margareth Canovan. $2^{\mathrm{a}}$ ed. Chicago: The University of Chicago Press, 1998.

Vida do espírito, A: o pensar, o querer e o julgar. 2 vol. $4^{\mathrm{a}}$ ed. Trad. Antônio Abranches, César Augusto R. de Almeida, Helena Martins; revisão técnica Antônio Abranches. Rio de Janeiro: Relume Dumará, 2000.

Responsabilidade e julgamento. Trad. Rosaura Eichenberg; revisão técnica Bethânia Assy e André Duarte; edição e introdução Jerome Kohn. $3^{\mathrm{a}}$ reimp. São Paulo: Companhia das Letras, 2003.

. Responsability and judgment. Edited and with a Introductin by Jerome Kohn. New York: Schocken Books, 2003b.

Compreender: Formação, exílio e totalitarismo. Ensaios 1930-54. Trad. Denise Bottman; organização e introdução Jerome Kohn. São Paulo: Companhia das Letras; Belo Horizonte: Editora UFMG, 2008.

Homens em tempos sombrios. Trad. Denise Bottman; posfácio Celso Lafer. São Paulo: Companhia das Letras, 2008b. 
Letras, 2011.

. Sobre a Revolução. Trad. Denise Bottmann. São Paulo: Companhia das

. Origens do totalitarismo. Trad. Roberto Raposo. $3^{\text {a }}$ reimp. São Paulo: Companhia das Letras, 2012.

Entre o passado e o futuro. Trad. Mauro Barbosa. $7^{\mathrm{a}}$ ed.; $1^{\mathrm{a}}$ reimp. São Paulo: Perspectiva, 2013.

. Promessa da política, A. Trad. Pedro Jorgensen Jr.; revisão técnica Eduardo Jardim; organização e introdução Jerome Kohn. 5a ed. Rio de Janeiro: DIFEL, 2013b.

Condição Humana, A. Trad. Roberto Raposo; revisão técnica e apresentação Adriano Correia. 12 $2^{\mathrm{a}}$ ed.; $2^{\mathrm{a}}$ reimp. Rio de Janeiro: Forense Universitária, 2015.

ARISTÓTELES. Política. Trad. António Campello Amaral e Carlos de Carvalho Gomes; revisão técnica Mendo Castro Henriques. Edição bilíngue. Lisboa: Veja, 1998.

Editori Laterza, 2005.

Etica Eudemia. Trad. Pierluigi Donini. Edição Bilíngue. 2a ed. Roma, Bari:

AUBENQUE, Pierre. Prudência em Aristóteles, A. Trad. Marisa Lopes. $2^{\mathrm{a}}$ ed. São Paulo: Discurso Editorial, Paulus, 2008.

BÁRCENA, Fernando e Mèlich, Joan-Carles. Educación como acontecimento ético, La: natalidade, narración y hospitalidade. Barcelona, Buenos Aires, Mexico: Ediciones Paidos, 2000 .

BATISTA, Eduardo Pereira. Platão sob o signo de Sócrates: um novo modelo de paideía. 2014. 114 p. Mestrado. Faculdade de Educação, Universidade de São Paulo, São Paulo, 2014.

BENSE, Max. Ensaio e sua prosa, O. Trad. Samuel Titan Jr. In. Revista Serrote. Vol. 16, 2014. Disponível em: https://www.revistaserrote.com.br/2014/04/o-ensaio-e-sua-prosa/ Consultado em 05 de outubro de 2020.

BENVENISTE, Émile. Vocabulário das instituições indo-europeias, O. Vol II. Trad. Denise Bottman e Eleonora Bottmann. Campinas: Editora Unicamp, 1995.

BIGNOTTO, Newton. O totalitarismo hoje? In: Aguiar, O. et al. (Org.). Origens do totalitarismo 50 anos depois. Rio de Janeiro: Relume Dumará, 2001.

CARVAlHO, J. S. Por uma pedagogia da dignidade: Memórias e reflexões sobre a experiência escolar. São Paulo: Summus, 2016.

Educação, uma herança sem testamento: diálogos com o pensamento de Hannah Arendt. São Paulo: Perspectiva: FAPESP, 2017.

Experiências temporais da vita activa e os desafios da transmissão intergeracional. In: Princípios: Revista de filosofia (UFRN), vol. 25, n. 48 (set.-dez.), pp. 259- 
280, 2018. Disponível em: <https://periodicos.ufrn.br/principios/article/view/14173>. Acesso em: 07 de mar. 2019.

CORREIA, Adriano. Sobre o trágico na ação: Arendt (e Nietzsche). In: O que nos faz pensar? n. 29, pp. 59-74, mai. 2011. Disponível em: $<$ http://oquenosfazpensar.fil.pucrio.br/import/pdf_articles/OQNFP 2905 adriano_correia.pdf $>$. Acesso $12 \mathrm{de}$ dez. 2018.

. Hannah Arendt e a modernidade: Política, economia e a disputa por uma fronteira. Rio de Janeiro: Editora Forense, 2014.

. Prefácio. In: CARVALHO, J. S. Educação, uma herança sem testamento. São Paulo: Perspectiva: FAPESP, 2017.

. Trágico, não absurdo: sobre a ação na obra de Hannah Arendt. In: Princípios: Revista de filosofia (UFRN), vol. 25, n. 48 (set.-dez.), pp. 157-170, 2018. Disponível em: $<$ https://periodicos.ufrn.br/principios/article/view/14173>. Acesso em: 07 de mar. 2019.

DUARTE, André. Hannah Arendt e a modernidade: esquecimento e a redescoberta da política. In: CORREIA, A. (Org.) Transpondo o abismo: Hannah Arendt entre a filosofia e a política. Rio de Janeiro: Forense, 2002.

. Hannah Arendt entre Heidegger e Benjamin: A crítica da tradição e a recuperação da origem política. In: MORAES, E. J., BIGNOTTO, N. (org.). Hannah Arendt: diálogos, reflexões, memórias. $1^{\text {a }}$ reimp. Belo Horizonte: Ed. UFMG, 2013.

FONTES, Joaquim Brasill. Eros, tecelão de mitos. $2^{\text {a }}$ ed. São Paulo: Iluminuras, 2003.

FOUCAULT, Michel. Omnes et singulatim: por uma crítica da "razão política". Trad. Heloísa Jahn. In: Revista Novos Estudos CEBRAP, v. 1, n. 26 (mar.), pp. 77-99, 1990. Disponível em: $<$ http://novosestudos.uol.com.br/produto/edicao-26/\#58db446f1881a>.

Acesso em: 11 de mai. 2020.

GAGNEBIN, Jeanne Marie. Uma filosofia do cogito ferido: Paul Ricoeur. In: Lembrar escrever esquecer. São Paulo: Editora 34, 2006.

GERALDI, João Wanderley. A aula como acontecimento. In: Aula como acontecimento, A. $2^{\mathrm{a}}$ ed. Campinas: Pedro e João Editores, 2015.

HADOT, Pierre. Exercícios espirituais e filosofia antiga. Trad. Flavio Fontenelle Loque e Loraine Oliveira. São Pauo: É Realizações, 2014.

HAN, Byung-chul. Agonia de Eros. Trad. Enio Paulo Giachini. Petrópolis: Editora Vozes, 2017.

HEIGEDDER, Martin. Ser e Tempo. Parte I. Trad. Márcia de Sá Cavalcante. Petrópolis: Editora Vozes, 1989.

. Ser e Tempo. Edição bilíngue. Trad. Fausto Castilho. Campinas: Editora da Unicamp; Petrópolis: Editora Vozes, 2012. 
KOSELLECK, Reinhart. Crítica e crise: uma contribuição à patogênese do mundo burguês. Trad. Luciana Villas-Boas Castelo-Branco. Rio de Janeiro: Contraponto, 1999.

KURY, Mário da Gama. Dicionário de mitologia grega e romana. $6^{\text {a }}$ ed. Rio de Janeiro: Jorge Zahar Editor, 2001.

LANJONQUIÈRE, Leandro. Figuras do infantil: a psicanálise na vida cotidiana com as crianças. Petrópolis: Editora Vozes, 2010.

LECOQ, Jacques. Corpo poético, O. Uma pedagogia da criação teatral. Trad. Marcelo Gomes. São Paulo: Edições SESC São Paulo, 2010.

LÓPEZ, Maximiliano V. Sobre el estudio: ócio, melancolia y cuidado. In: Revista Interuniversitaria Teoría de la Educacíon, Salamanca, v. 31, n. 2 (jul.- dez.), p. 69-86, 2019. Disponível em: $<$ https://revistas.usal.es/index.php/1130-3743/article/view/21145>. Acesso em: 24 de mar. 2020.

MARROU, Henri-Irénée. História da educação na antiguidade. Trad. Mário Leônidas Cassanova. São Paulo: E.P.U.; Editora da Universidade de São Paulo, 1973.

MARX, Karl. 18 de Brumário de Luís Bonaparte, O. In: Manuscritos econômicos-filosóficos e outros textos escolhidos. Trad. José Carlos Bruni (et al.). $2^{\mathrm{a}}$ ed. São Paulo: Abril Cultural, 1978 .

MASSCHELEIN, J., SIMONS, M. Em defesa da escola: uma questão pública. Trad. Cristina Antunes. $2^{\mathrm{a}}$ ed.; $1^{\mathrm{a}}$ reimp. Belo Horizonte: Autêntica Editora, 2015.

MONTESQUIEU. Espírito das leis, O. Trad. Cristina Marachco. São Paulo: Martins Fontes, 1996.

NIETZSCHE, FRIEDRICH. Genealogia da moral: uma polêmica. Trad. Paulo César de Souza. São Paulo: Companhia das Letras, 2009.

NUSSBAUM, Martha. Fragilidade da bondade, A. Fortuna e ética na tragédia e na filosofia grega. Trad. Ana Aguiar Cotrim. São Paulo: Editora WMF Matins Fontes, 2009.

PLATÃO. República, A. Trad. Maria Helena da Rocha Pereira. $8^{\mathrm{a}}$ ed. Lisboa: Fundação Calouste Gulbenkian, 1996.

RANCIÈRE, J. La méthode de l'égalité: Entretetien avec Laurent Jeanpierre e Dork Zabunyan. Paris: Bayard Éditions, 2012.

. Espectador Emancipado, O. Trad. Ivone C. Benedetti. São Paulo: Editora

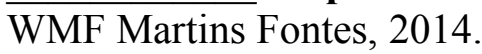

KKYM, 2014b.

Nas margens do político. Trad. Vanessa Brito e João Pedro Cachopo. Lisboa: 
. Tempo da emancipação já passou?, O. In: SILVA, R. e NAZARÉ, L. (Org.). República porvir, A: Arte, política e pensamento para o século XXI. $2^{\mathrm{a}}$ ed. Lisboa: Fundação Calouste Gulbenkian, 2015.

. Fio perdido, O: Ensaios sobre a ficção moderna. Trad. Marcelo Mori. São Paulo: Martins Fontes, 2017.

. Ecole, production, égalité. In: L'ecole de la democracie. Paris: Edilig, Fondation Diderot, 1988. Disponível em: <http://horlieu-editions.com/textes-enligne/politique/ranciere-ecole-production-egalite.pdf $>$. Acesso em: 23 de mar. de 2018.

. Escola, produção, igualdade. Trad. Grupo de Estudo e Pesquisa sobre Educação e Pensamento Contemporâneo (GEPEC-USP) (s.d.).

. Desentendimento: Política e filosofia. Trad. Ângela Leite Lopes. $2^{\mathrm{a}}$ ed. São Paulo: Editora 34, 2018.

. Mestre ignorante, O. Cinco lições sobre a emancipação intelectual. Trad. Lilian do Valle. $3^{\mathrm{a}}$ ed.; $7^{\mathrm{a}}$ reimp. Belo Horizonte: Autêntica Editora, 2018.

RICOUER, Paul. Symbole donne à penser, Le. In: Revue Esprit, no. 27 (jul.-ago.), pp. 59-76, 1959.

. Du texte à l'action. Essais d'herméneutique, II. Paris: É ditions du Seuil, 1986.

. Conflito das interpretações, O. Ensaios de hermenêutica. Trad. M. F. Sá Correia. Porto: Editora Rés, 1988.

Papirus, 1994.

. Tempo e Narrativa. Tomo 1. Trad. Constança Marcondes Cesar. Campinas:

. Leituras 1: em torno do político. Trad. Marcelo Perine. São Paulo: Loyola, 1995.

. Réfletion faite. Autobiographie intellectualle. Paris: Le Seuil, 1995b.

. Lectures 1: autour du politique. Paris: Éditions du Seuil, 1999.

. Temps et récit. Tome I. Paris: Éditions du Seuil, 1999 b.

. Si-mesmo como outro, O. Trad. Ivone C. Benedetti. São Paulo: Editora WMF Martins Fontes, 2014.

Préface. In: ARENDT, H. Condition de l'homme moderne. Trad. George Fradier. $1^{\text {a }}$ reimp. Paris: Pocket, 2016.

SCHEFFLER, Israel. Linguagem da educação, A. Trad. Balthazar Barbosa Filho. São Paulo: Editora da Universidade de São Paulo, 1974.

SCHELER, Max. El posto del hombre en el cosmo. Trad. José Gaos. 20a ed. Buenos Aires: Editorial Losada, 1994. 
TASSIN, Etienne. Espace comum ou espace public? L'antagonisme de la communauté et de la publicité. In: Revue Hermès, n. 10, p. 23-37, 1991.

UNIVERSIDADE DE SÃO PAULO. Diretrizes para apresentação de dissertações e teses da USP: parte I (ABNT)/Agência USP de Gestão de Informação Acadêmica; Vânia Martins Bueno de Olivera Funaro (et al.). 4ª ed. São Paulo: AGUIA, 2020.

WOLIN, Sheldon. Hannah Arendt and the ordinance of time. In: Social Reserch. Vol. 44, no. $1,1977$.

\section{FILMES}

PARASITA. Direção: Bong Joon-ho. Produção: Kwak Sin-ae, Moon Yang-kwon, Jang Young-hwan. Intérpretes: Song Kang-ho, Choi Woo-shik, Park So-dam, Cho Yeo-Jeong. Roteiro: Bong Joon-ho e Han Jin-won. Coreia do Sul: Baruson E\&A corp., 2019. 1 bobina cinematográfica (132 min.), son., cor. 